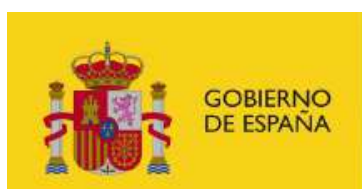

MINISTERIO

DEAGRICULTURA, ALIMENTACIÓN

Y MEDIO AMBIENTE

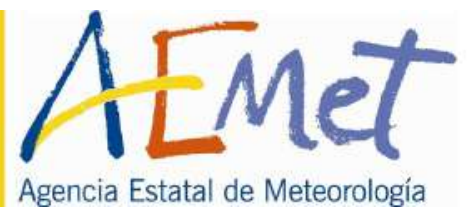

Agencia Estatal de Meteorología

\title{
Características básicas de las supercélulas en España
}

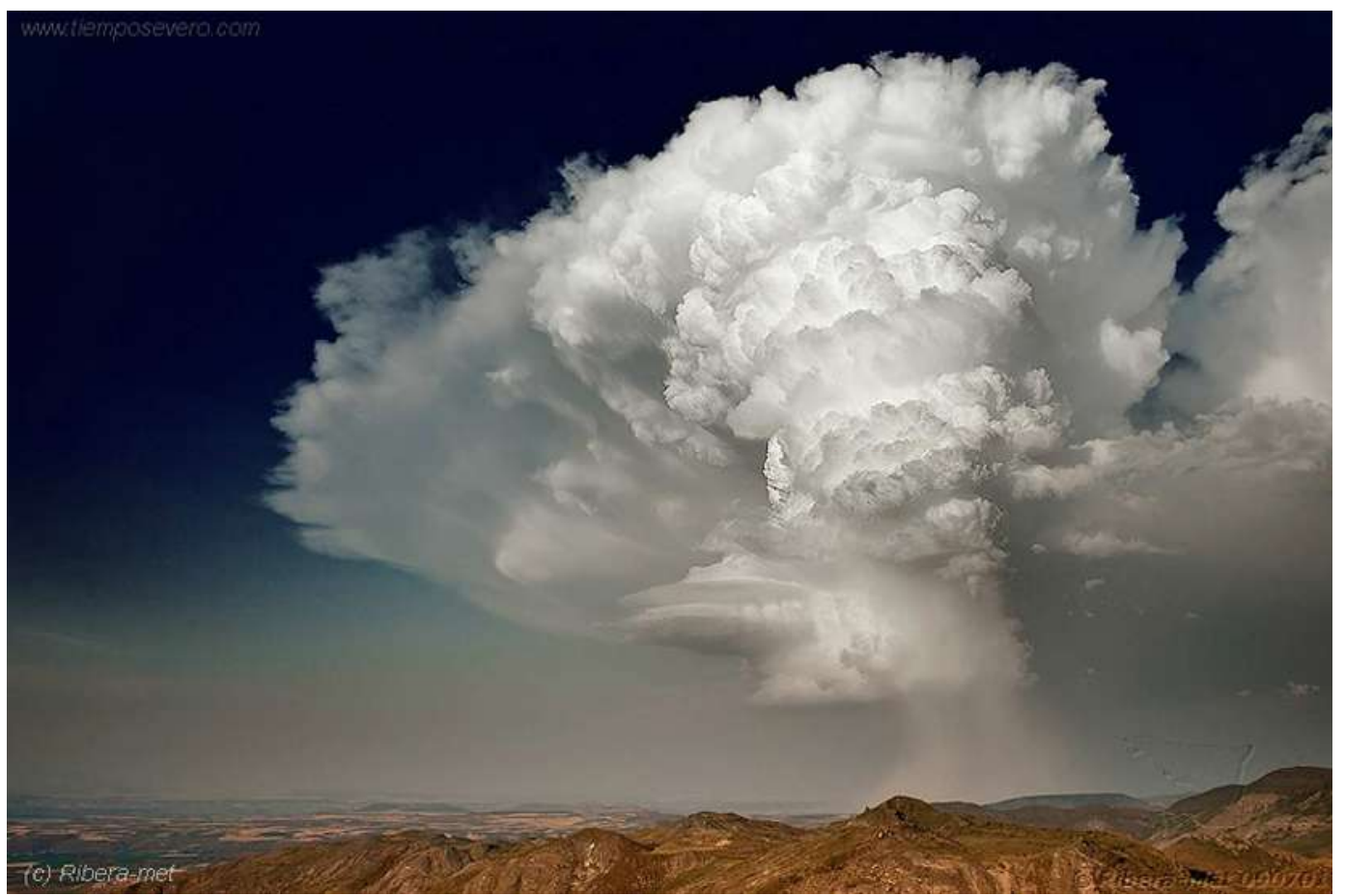

Supercélula anticiclónica en Ribafrecha (La Rioja), 1 de Julio de 2009 Foto (C) Antonio Carramiñana Calzada

$$
\begin{gathered}
\text { José Antonio Quirantes Calvo } \\
\text { Jesús Riesco Martín } \\
\text { José Ángel Núñez Mora }
\end{gathered}
$$




\section{datos}

\section{abiertos}

Aviso Legal: los contenidos de esta publicación podrán ser reutilizados, citando la fuente y la fecha, en su caso, de la última actualización.

\section{Edita:}

(C) Ministerio de Agricultura, Alimentación y Medio Ambiente Agencia Estatal de Meteorología Madrid, 2014

Catálogo de Publicaciones de la Administración General del Estado: https://cpage.mpr.gob.es

NIPO: 281-14-008-X

https://doi.org/10.31978/281-14-008-X

Agencia Estatal de Meteorología (AEMET)

$\mathrm{C} /$ Leonardo Prieto Castro, 8

28040 Madrid

http://www.aemet.es/

\section{@Aemet_Esp}

https://www.facebook.com/AgenciaEstataldeMeteorologia 


\section{ÍNDICE}

\section{1.- Introducción}

\section{2.- Revisión básica del concepto de supercélula}

3.- Supercélulas en España: identificación y dificultades en su catalogación

\section{4.- Casos de estudio}

\section{5.- Conclusiones}

\section{6.- Referencias}

\section{RESUMEN}

Se presenta un trabajo de carácter divulgativo sobre las características básicas de las supercélulas en España. Se analizará el concepto de supercélula y se presentarán ideas generales sobre patrones típicos en la identificación de las mismas.

\section{Palabras clave:}

Supercélula, radar, observación visual, entornos convectivos severos, patrones radar, mesociclón, viento radar Doppler, modelo conceptual.

\section{Agradecimientos:}

A todos los aficionados a la meteorología en España. Especialmente a los que comparten información de tiempo severo en los foros, y en particular al foro de Meteored http://foro.tiempo.com/ y a sus colaboradores por la información tan valiosa que muestran en el apartado de seguimiento de posibles supercélulas en España.

Al cazatormentas americano Mike Hollingshead, por la cesión de los derechos de reproducción de varias de sus mejores fotografías de supercélulas para la documentación de este trabajo.

A los autores de las fotografías, Mike Hollingshead, José Antonio Gallego Poveda, David Mancebo Atienza, Antonio Carramiñana Calzada, Alberto Lunas Arias, Manuel Massagué Conde, David Momblona Montiel, Miguel Cívica Corrales y David Ávila.

Y a las personas que han revisado exhaustivamente el documento, Francisco Martín León, Ismael San Ambrosio Beirán, Ramón Pascual Berghaenel, José Miguel Gutiérrez Núñez, David Momblona Montiel y Miguel Cívica Corrales. 


\section{1.- Introducción}

Aunque la existencia de supercélulas en España es un hecho incuestionable, este tipo de estructuras convectivas deben ser caracterizadas, dentro de lo posible, bajo unos criterios objetivos y básicos para intentar ser capaces de discriminar entre supercélulas y otro tipo de tormentas. El fin perseguido, aunque complejo, se entiende necesario de cara a la consecución de una cierta unificación de ideas sobre algunas características observacionales básicas de las supercélulas en España, estructuras por un lado mitificadas y por otra parte trivializadas en ciertos sentidos.

Si bien es verdad que la generación de supercélulas en España no es un hecho demasiado raro, tampoco es ésta la forma típica de célula convectiva observada, ya que predominan las estructuras unicelulares de escasa organización o bien las multicelulares de organización media-alta. Esto es así porque para la génesis de una supercélula son necesarias simultáneamente condiciones de inestabilidad y sobre todo de cizalladura vertical en los primeros kilómetros de la atmósfera y de helicidad relativa a la tormenta, que deben tomar valores elevados, algo no demasiado usual en la atmósfera.

Las supercélulas más severas del planeta se generan en las grandes llanuras de EEUU, por lo que sin duda, una interesante opción para la elaboración de este trabajo fue acudir a las fuentes del conocimiento experto en la materia. Para ello se han contrastado, de manera informal y particular, dudas teóricas y prácticas que han ido surgiendo durante el proceso de elaboración de este documento, con la opinión de diversos meteorólogos especialistas en convección severa en Estados Unidos.

El objeto de ese documento divulgativo no es una revisión teórica de la dinámica supercelular, sino que es eminentemente práctico y se orienta hacia la caracterización de la identificación de supercélulas en España. No obstante se requiere en primer lugar fijar algunos conceptos básicos y generales sobre este tipo de estructuras. Por todo lo anterior el documento engloba los siguientes temas clave.

El capítulo 2 contiene una revisión básica teórica del concepto de supercélula, que como se verá contiene cierta subjetividad en las definiciones existentes. No obstante se hará mención a las propiedades básicas, tipo de supercélulas, dinámica e ingredientes necesarios para su formación.

El capítulo 3 versa sobre los modos de identificación, visual y a partir del radar, de las supercélulas en general y en concreto en España, poniéndose de manifiesto las innegables dificultades existentes en bastantes episodios.

El bloque 4 está dedicado a documentar casos concretos de supercélulas en España, tratando de plasmar la diferente disponibilidad de información en cada caso, la existencia de distintos tipos de supercélulas y las dificultades en algún episodio para su caracterización.

En el apartado 5 se introducen las conclusiones básicas que se recogen de modo esquemático.

Por último, se incluyen las referencias bibliográficas.

NOTA: Para que las personas neófitas en el tema de las supercélulas puedan seguir los conceptos usados en este documento, se han incluido en las referencias diversos trabajos de interés en distintos campos relacionados directa o indirectamente con las supercélulas. En especial se recomienda por su sencillez divulgativa introductoria, la guía sobre fenomenología de tormentas severas llamada Weather Spotter's Field Guide de la NOAA. También muy ilustrativos son los módulos COMET (UCAR) relacionados con la convección. No obstante en la bibliografía se incluyen algunos trabajos y referencias en internet que se entienden fundamentales. Por último hay que destacar que en muchos casos se ha preferido utilizar la nomenclatura anglosajona, ampliamente seguida en la terminología científica y por los grupos de aficionados y "cazatormentas". 


\section{2.- Revisión básica del concepto de supercélula}

\section{1.- Definición}

Dentro de la convección organizada (bastante menos frecuente que la no organizada), básicamente nos podemos encontrar con los siguientes sistemas o estructuras: multicélulas tipo "cluster" no estacionarias, multicélulas tipo "cluster" estacionarias o con efecto de "tren convectivo", líneas de turbonada o "squall-line" (con o sin "bow-echoes"), sistemas convectivos de mesoescala (SCM), complejos convectivos de mesoescala (CCM), "derechos" y supercélulas.

Las supercélulas, que fueron definidas originalmente por Browning (1962, 1964), representan la forma más organizada, severa y de larga duración de la convección profunda aislada. En general, en todo el mundo, los casos de severidad más grave están ligados a supercélulas. De hecho la gran mayoría de todos los reportes de granizo de diámetro superior a $5 \mathrm{~cm}$ proceden de supercélulas, así como una buena parte de tornados violentos (EF2 o superior). Las supercélulas también pueden provocar grandes cantidades de descargas eléctricas, pudiendo superar tasas de 200 por minuto, y quizás de este hecho proceda su nombre original de supercélulas (Markowski y Richardson, 2010).

Sin embargo hay un consenso actual en favor de definir las supercélulas merced a un criterio dinámico. De acuerdo con esto, en la actualidad se suele definir una supercélula como una tormenta que posee un profundo y persistente mesociclón (Doswell and Burgess, 1993), aunque esta caracterización puede verse sometida a distintos matices e interpretaciones.

- Por profundo se puede entender, en general, que la distribución vertical del mesociclón afecte a una significativa parte de la corriente ascendente del cumulonimbo en el que está, es decir, que posea una profundidad de $1 / 3$ ó $1 / 2$ (según diferentes autores) del total, lo que significa normalmente entre 3 y 6 kilómetros. Se puede decir que el mesociclón es una fracción, en continua rotación, del total de la corriente ascendente.

- Por persistente se suele entender unas pocas decenas de minutos (escala convectiva). Aproximadamente, sería el tiempo necesario para que una parcela de aire pasase desde la base de la nube hasta su tope a través de toda la corriente ascendente del cumulonimbo. Del orden de 20 ' a 30 '.

Por tanto el mesociclón sería una zona en rotación, de vorticidad vertical con una magnitud del orden de $10^{-2} \mathrm{~s}^{-1}$ y con un ancho horizontal de entre 3 y $10 \mathrm{~km}$, aproximadamente. Así, quedarían fuera del concepto de supercélula diferentes vórtices de pequeña escala, o poco profundos, o de escasa duración, que frecuentemente se observan asociados a la presencia de inestabilidad y cizalladura, por ejemplo en frentes de racha.

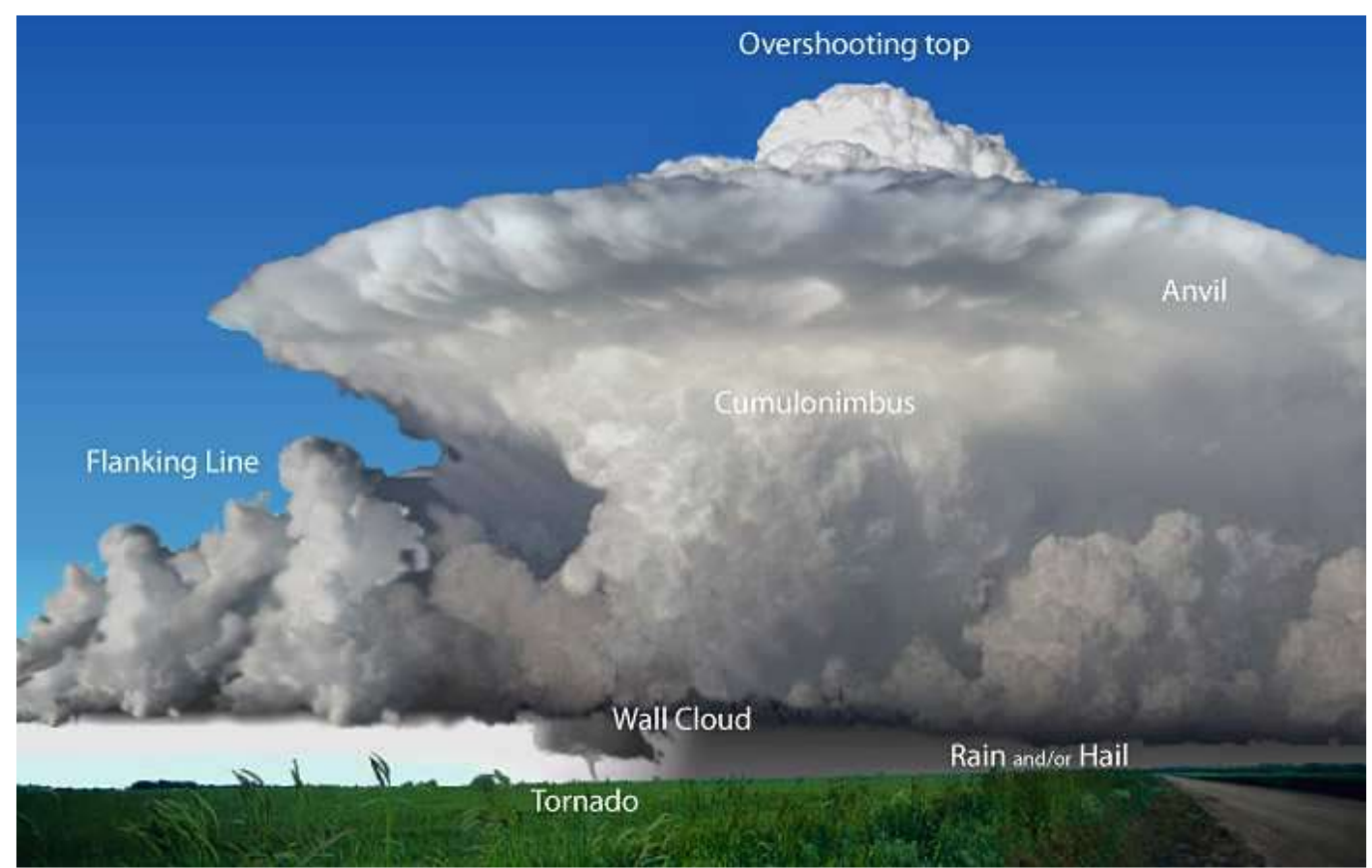

Figura 2.1. Tormenta supercelular y posibles elementos asociados (que se verán más adelante en el texto). Fuente: Weather Spotter's Field Guide. National Weather Service (NWS). 


\section{2.- Tipos de supercélulas}

\subsection{1- Supercélulas clásicas, LP y HP}

Todas las supercélulas contienen rotación a escala convectiva, detectable mediante la visualización de estrías o una apariencia de sacacorchos en la corriente ascendente. Dentro de las categorías de supercélulas hay diferencias en función de su aspecto (Doswell y Burguess, 1993), especialmente a partir de la cantidad y distribución espacial de la precipitación (si cae cerca o lejos de la corriente ascendente), lo cual permite distinguir unas supercélulas de otras.

\section{Supercélulas LP}

Producen una cantidad de precipitación relativamente pequeña mostrando claros signos visuales de rotación. Estas tormentas son las denominadas supercélulas de baja precipitación (figura 2.2), Low Precipitation supercells -LP- (Bluestein and Parks, 1983), que normalmente dan poca señal de la rotación en las imágenes radar. Frecuentemente presentan forma de poste de barbero o sacacorchos, y la precipitación suele estar bien separada de la corriente ascendente debajo de la base nubosa.

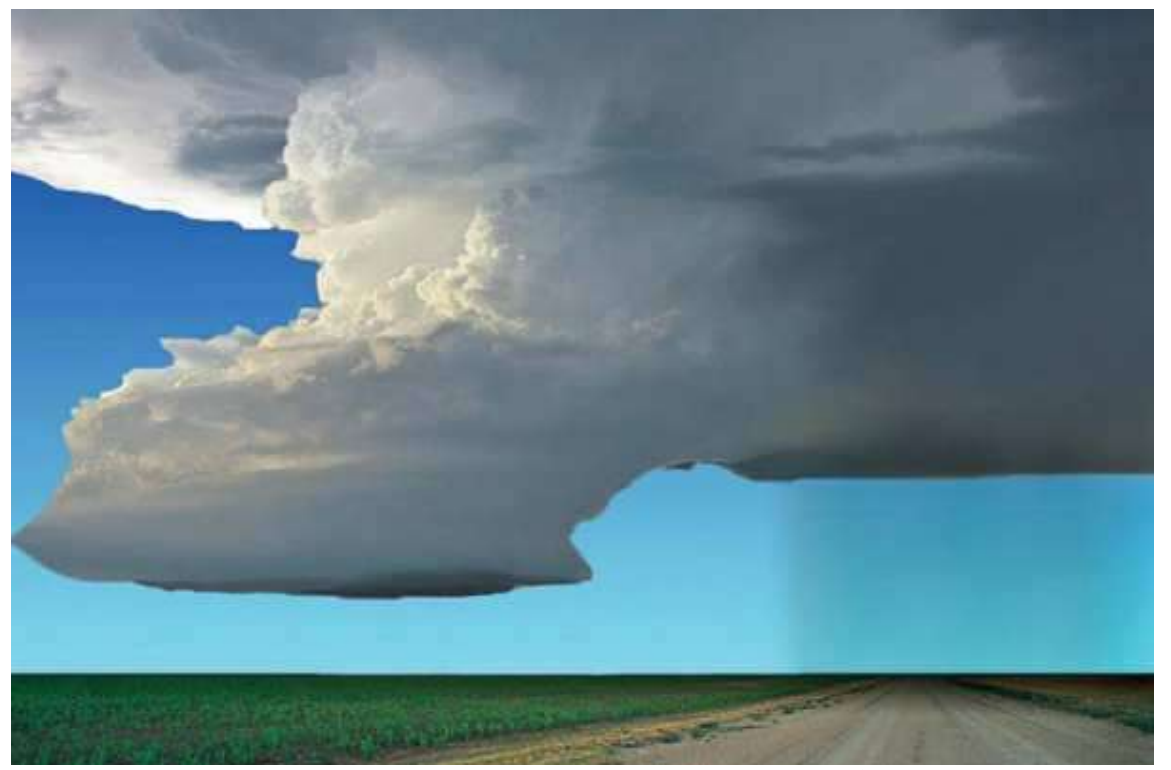

Figura 2.2. Reproducción de una supercélula LP. Fuente: Weather Spotters Field Guide (NWS).

\section{Supercélulas HP}

Son el tipo opuesto al anterior, y se llaman supercélulas de alta precipitación (figura 2.3), High Precipitation supercells -HP-. Suelen mostrar intensa reflectividad radar en la zona del gancho. Al formarse en entornos de importante humedad y nubosidad, la rotación suele ser difícilmente observable a simple vista, ya que a menudo la precipitación envuelve a la corriente ascendente y puede ocultarla. Algo similar ocurre a veces con la ocultación de la pared nubosa por precipitación intensa. Sin embargo, sí producen una significativa señal en el radar.

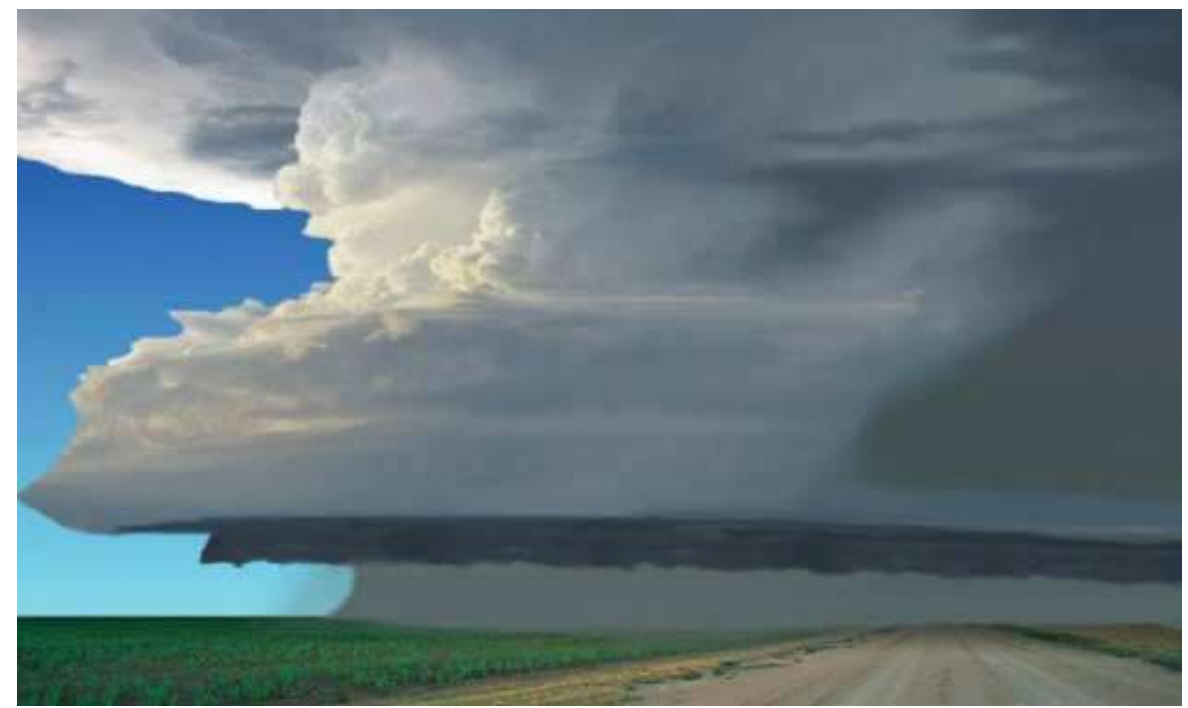

Figura 2.3. Reproducción de una supercélula HP. Fuente: Weather Spotters Field Guide (NWS). 


\section{Supercélulas clásicas}

Se encuentran entre los dos extremos de supercélulas de baja y alta precipitación. Las supercélulas clásicas son fácilmente detectables visualmente y a partir del radar. Además pueden producir una variada gama de tiempo severo asociado. Según observaciones hechas por cazatormentas la mayoría de las supercélulas en España serían de esta categoría, mientras que las más frecuentes en EEUU son las HP. En estos casos la precipitación intensa cae junto a la corriente ascendente.

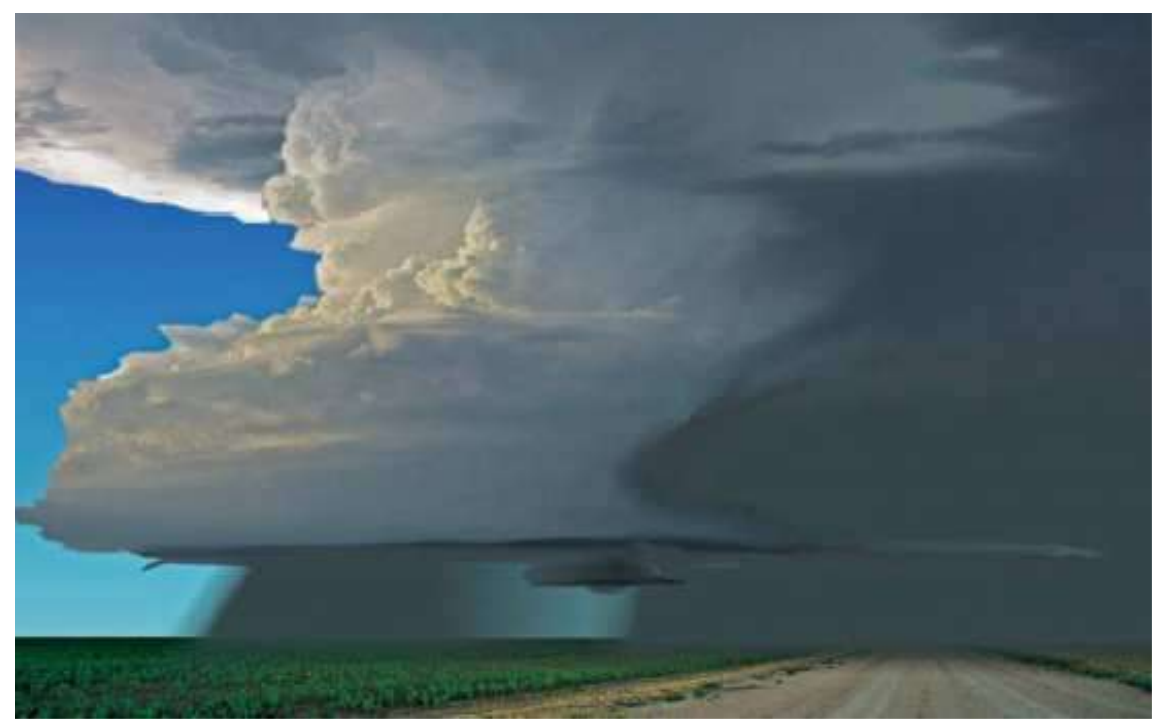

Figura 2.4. Reproducción de una supercélula clásica. Fuente: Weather Spotters Field Guide (NWS).

\subsection{2- Minisupercélulas}

Estudios usando el radar Doppler del National Weather Service de EEUU (WSR-88D), han puesto de manifiesto la existencia de un cierto número de supercélulas que son más pequeñas en extensión horizontal y vertical que las de las grandes Llanuras (Burgess et al, 1995). Posteriores estudios a partir de modelización, tales como el de Wicker y Cantrell (1996), han demostrado que las minisupercélulas siguen teniendo las mismas características, aunque a una escala menor. Entre ellas se encuentran algunos de los patrones clásicos de supercélulas que luego se revisarán brevemente en este documento, tales como los ecos en gancho, las zonas WER y BWER y los mesociclones. Estos mesociclones parecen disponer de menor velocidad de giro, diámetro inferior y extensión vertical más pequeña al compararlos con los de las supercélulas típicas de las grandes llanuras norteamericanas.

En España, un cierto número de supercélulas (10-15\%) tiene propiedades similares a las minisupercélulas americanas, presentando una estructura similar a las supercélulas clásicas, pero con dimensiones menores en cuanto a tamaño horizontal y vertical. Son supercélulas en miniatura o minisupercélulas, pero en esencia, supercélulas, con la típica estructura radar que veremos más adelante.

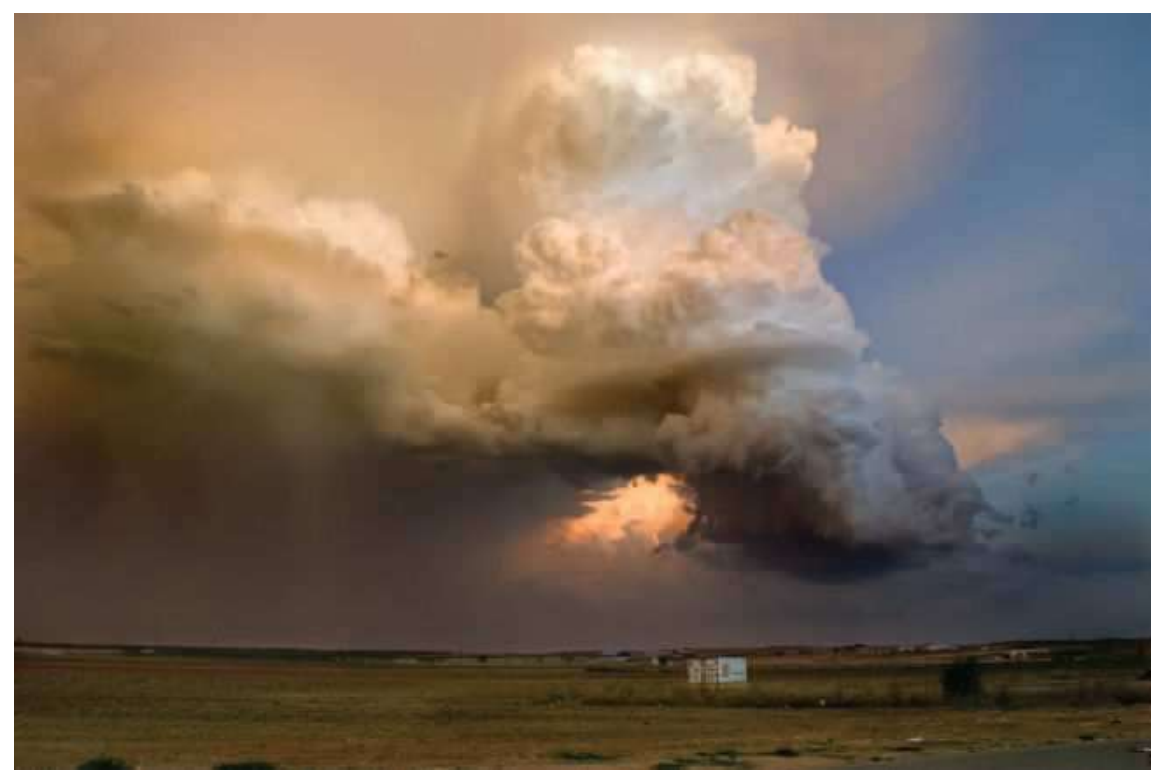

Figura 2.5. Ejemplo de mini-supercélula producida en Sisante (Cuenca), 27-agosto-2008. Foto (C) José Antonio Gallego Poveda 


\section{3- Resumen de la dinámica de las supercélulas}

Existen dos importantes características diferenciales de las supercélulas respecto a los demás tipos de tormentas.

- Presencia de una intensa corriente ascendente que contiene un profundo y persistente mesociclón. El sentido del giro de la corriente ascendente puede ser ciclónico (mesociclón) o anticiclónico (mesoanticiclón), por lo que existirán supercélulas ciclónicas y supercélulas anticiclónicas.

- Anómala naturaleza de su propagación, desviándose de manera significativa del flujo del viento rector o respecto al movimiento observado del resto de las tormentas de su entorno. Las supercélulas ciclónicas (anticiclónicas) tienden a desviarse hacia la derecha (izquierda) del viento medio, a veces de manera muy significativa.

\subsection{1.- Corriente ascendente en un entorno de cizalladura unidireccional}

A continuación se resumen de manera sencilla algunas de las particularidades básicas de la dinámica supercelular, utilizando contenido didáctico extraído del módulo COMET denominado "Principios de Convección III. Cizalladura y tormentas convectivas". Se supone que nos encontramos en el Hemisferio Norte.

Un perfil atmosférico que en los tres primeros kilómetros de la vertical (aproximadamente) presenta cizalladura vertical unidireccional (sin cambio de dirección), conduce a giros verticales (figura 2.6.izda), o sea, a la creación de vorticidad horizontal. También los gradientes horizontales de empuje hidrostático generan vorticidad horizontal. En la figura 2.6.dcha se observa cómo de la expansión lateral de una bolsa de aire frío se genera vorticidad horizontal negativa en el borde derecho y vorticidad horizontal positiva en el margen izquierdo.

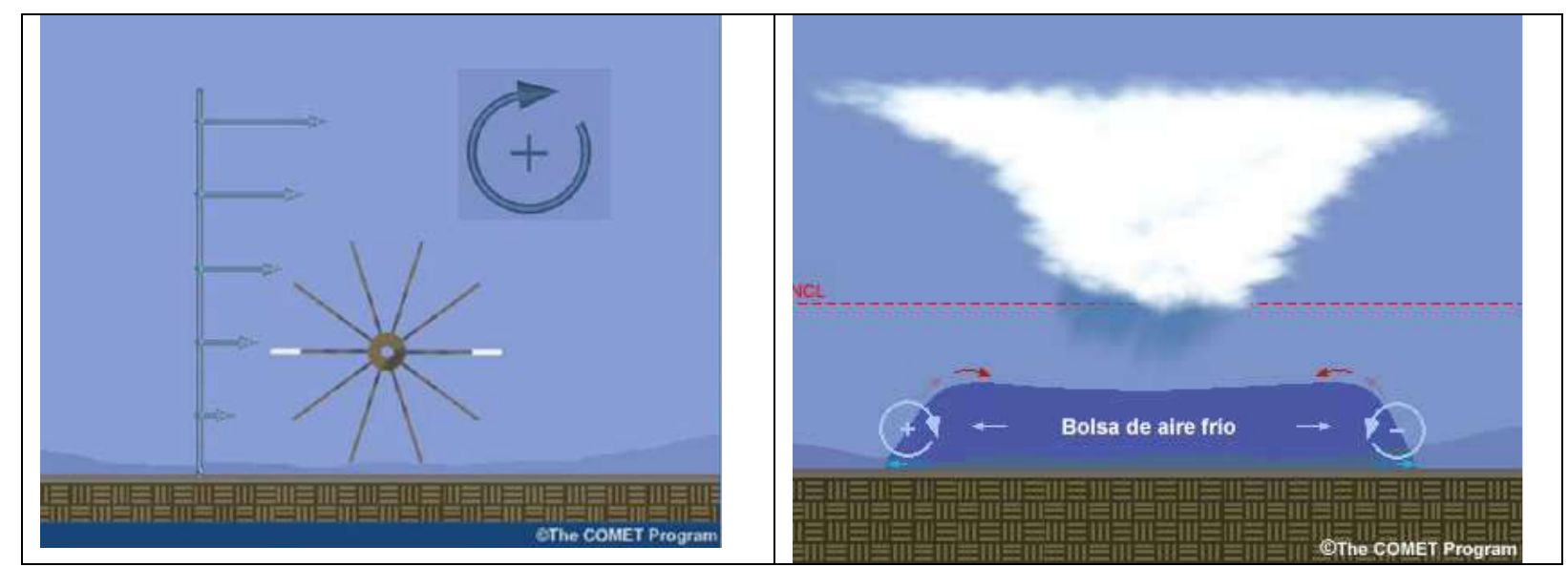

Figura 2.6. Izda: Cizalladura vertical de viento promotora de vorticidad de eje horizontal. Dcha: vorticidades opuestas generadas a ambos lados de los bordes de una bolsa de aire frío. Fuente: The Comet Program

A partir de la regla de la mano derecha podremos saber si la vorticidad horizontal es ciclónica o anticiclónica (figura 2.7).

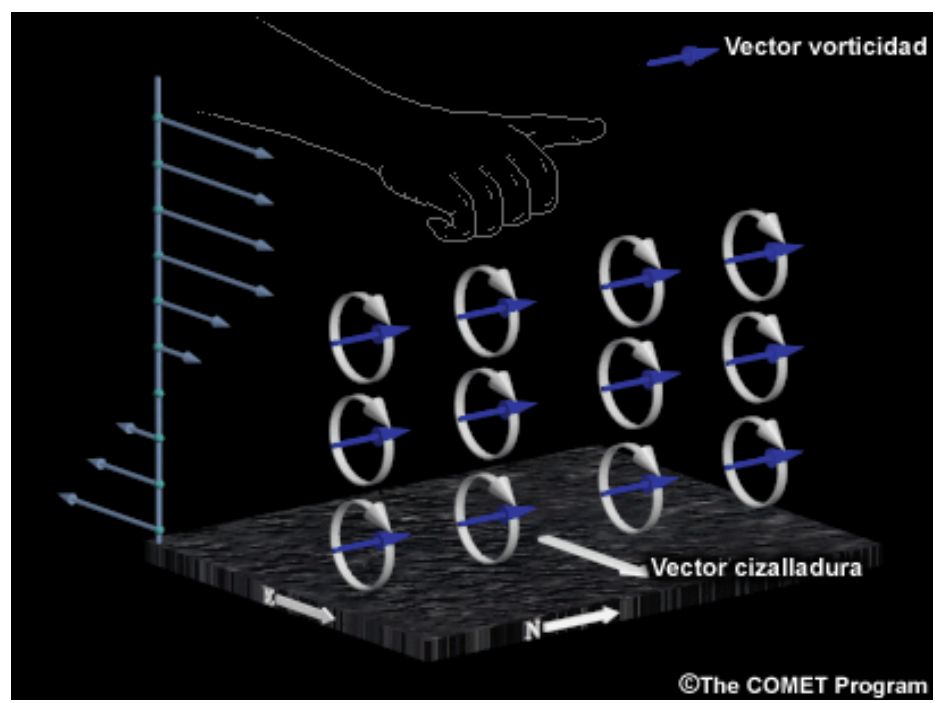

Figura 2.7. Vorticidad horizontal anticiclónica fruto de la existencia de cizalladura vertical de viento (sólo en intensidad). Se observa cómo el vector vorticidad horizontal es perpendicular al vector cizalladura. Fuente: The Comet Program 
Si consideramos una corriente ascendente, se generará vorticidad horizontal a ambos lados, positiva a la derecha y negativa a la izquierda. En un entorno sin cizalladura vertical de viento, la vorticidad horizontal positiva se mantiene en equilibrio con la vorticidad horizontal negativa y la corriente ascendente sigue una trayectoria vertical, sin inclinarse (figura 2.8.izquierda).

En cambio si la cizalladura vertical del viento es profunda, la vorticidad horizontal asociada a esta capa de cizalladura profunda, se añade a la vorticidad horizontal debida al gradiente de empuje hidrostático en la corriente ascendente. Esto provoca la inclinación de la tormenta hacia el lado en que la vorticidad horizontal tiene el mismo signo que el entorno. O sea, la tormenta se inclina hacia el vector cizalladura, es decir, en la dirección de propagación de la cizalladura (figura 2.8.derecha).

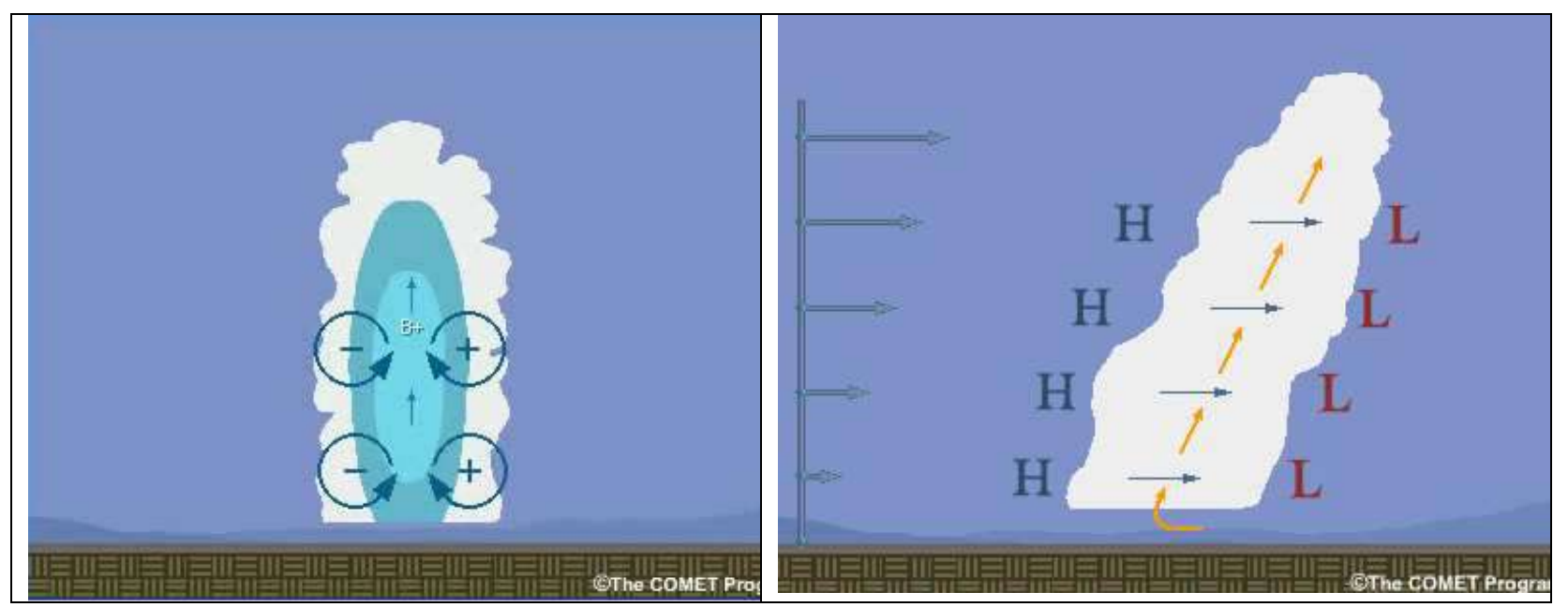

Figura 2.8. No inclinación (inclinación) de la corriente ascendente en entorno de no cizalladura (cizalladura) vertical de viento. Fuente: The Comet Program

Podemos tener en cuenta además otro efecto debido a la interacción entre la cizalladura y la corriente ascendente. Si la columna de aire ascendente bloquea parcialmente el flujo ambiental, crea un efecto dinámico de alta presión relativa en el lado de donde procede la cizalladura, y de baja presión en el de la dirección de propagación de la cizalladura de la corriente ascendente (figura 2.9). El factor que realmente provoca la inclinación de la parcela ascendente en la dirección de propagación de la cizalladura, provocando la inclinación de la corriente convectiva, es la fuerza del gradiente de la presión desde la zona de alta presión hasta la de baja presión que atraviesa la corriente ascendente.

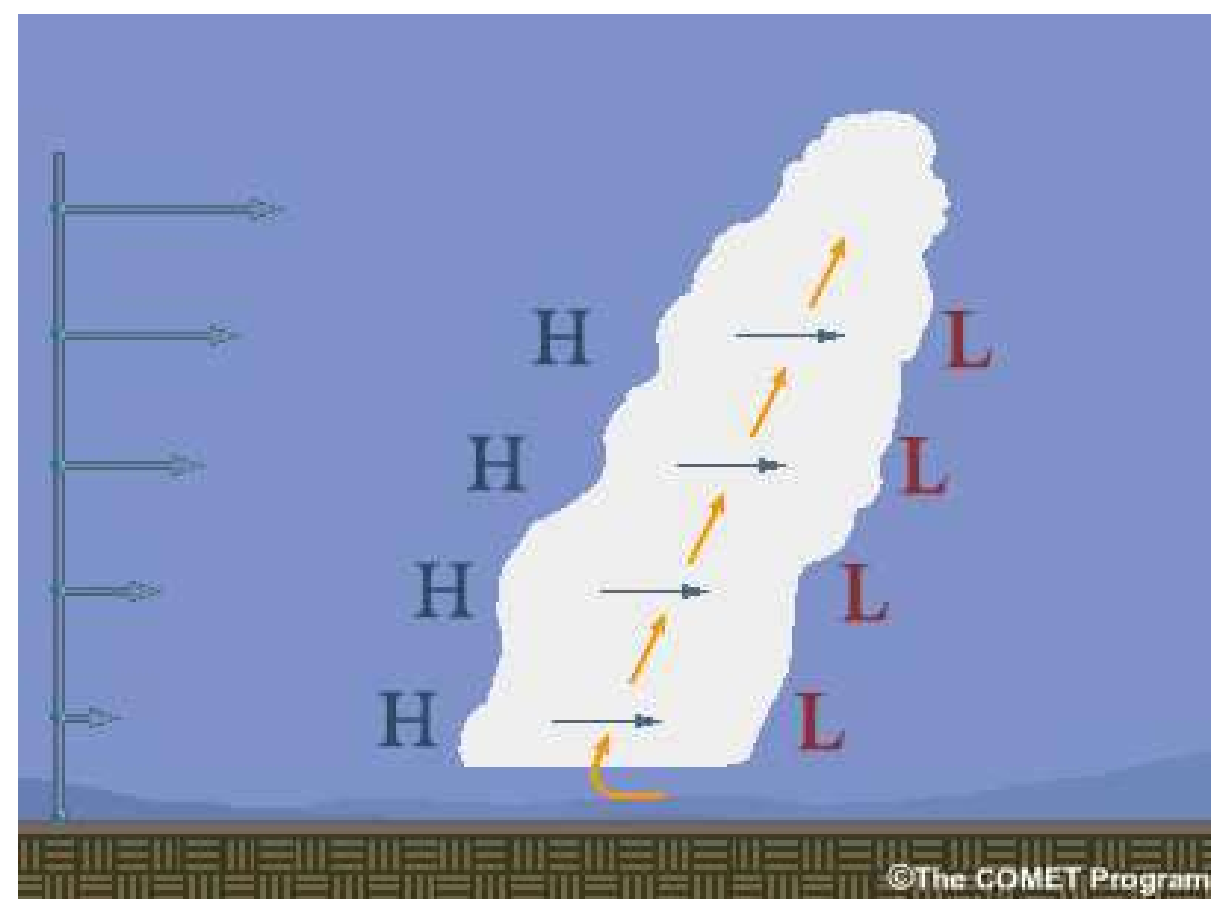

Figura 2.9. Patrón de la disposición de perturbación de presión lineal asociada a un perfil de cizalladura vertical unidireccional. Fuente: The Comet Program 
Lo que ocurre por tanto con una corriente vertical en un entorno de cizalladura unidireccional, es que el rodillo de vorticidad horizontal inicial es inclinado por la corriente ascendente, convirtiéndose en un par de rodillos de giros opuestos (Weisman, 1982), tal y como sugiere la figura 2.10. Estos vórtices se forman en los bordes izquierdo y derecho de la corriente vertical y están asociados a bajas dinámicas. Dentro de estas bajas a escala de tormenta, la presión es más baja en niveles medios, donde la corriente vertical (y por tanto la inclinación de la vorticidad horizontal) es más intensa (figura 2.10).

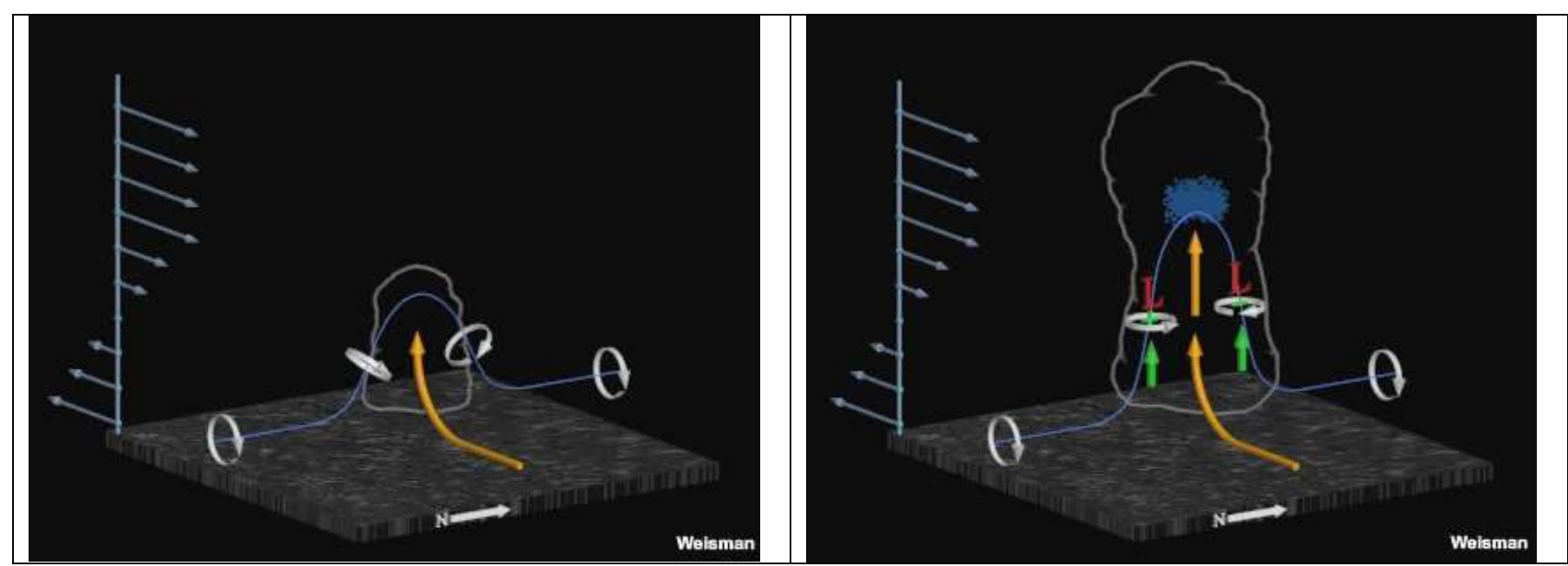

Figura 2.10. Izda. Inclinación de los vórtices horizontales por una corriente vertical ascendente en un entorno de cizalladura unidireccional. Dcha: Modelo conceptual de las bajas a escala tormentosa asociadas con la circulación en niveles medios a ambos bordes de la corriente vertical ascendente. Fuente: The Comet Program

Como resultado, la fuerza del gradiente de presión debida a la perturbación de la corriente ascendente genera otros nuevos ascensos cerca del centro de cada vórtice de niveles medios. Este desarrollo ensancha la corriente ascendente original mediante el crecimiento de nuevos e intensos ascensos en los lados izquierdo y derecho. Una vez que la corriente ascendente (updraft) no soporta el peso de la precipitación, ésta comienza a desplomarse sobre la propia corriente ascendente (figura 2.11). La tormenta original se divide en dos, generándose dos células independientes. Es lo que se denomina "storm splitting" (una división de la tormenta en dos).

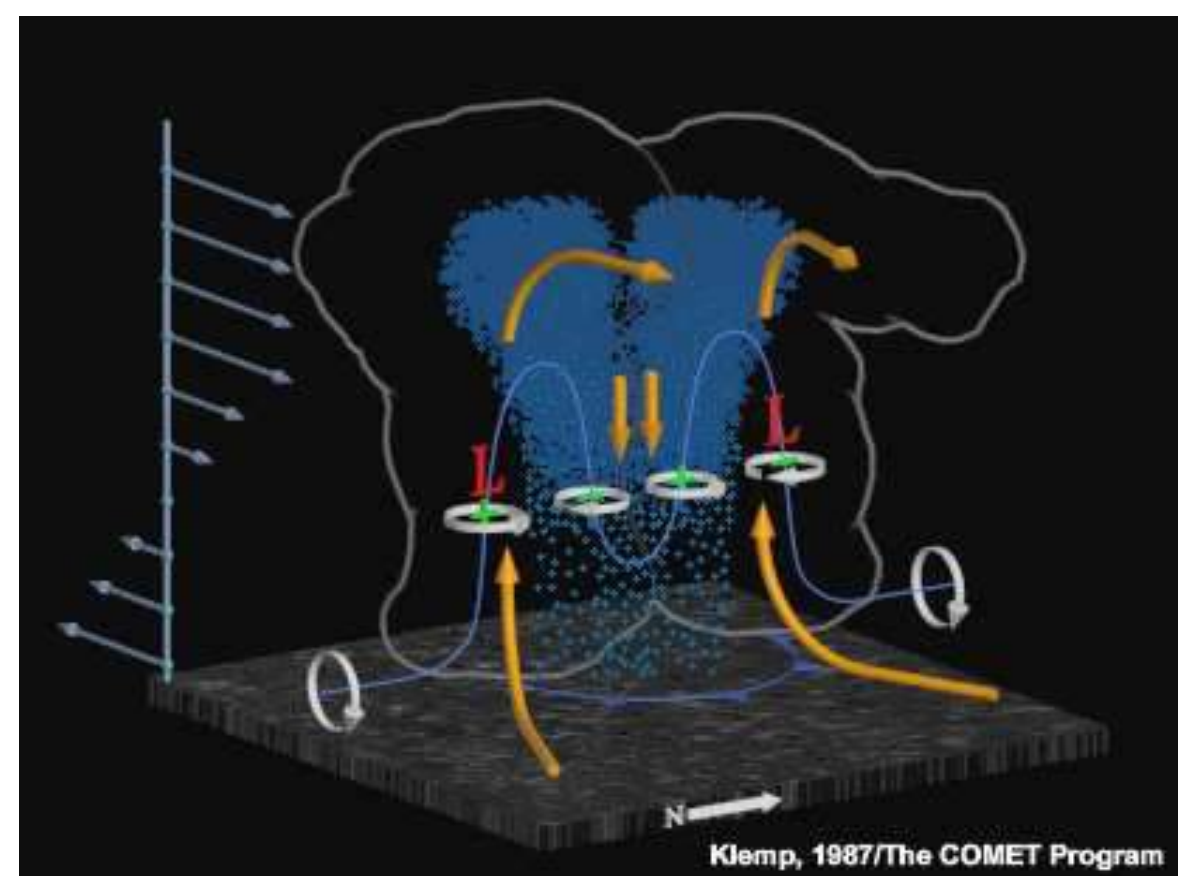

Figura 2.11. Esquema de la división tormentosa ("storm-splitting") en dos células. Fuente: The Comet Program

A un storm-splitting se llega a partir de entornos convectivos con grandes valores de cizalladura vertical unidireccional. Tras un storm-splitting (figuras 2.11 y 2.12) habrá en total 4 vórtices, dos asociados a las dos corrientes ascendentes y otros dos a las corrientes descendentes. Después del storm-splitting es frecuente que una de las tormentas progrese a supercélula, dependiendo del tipo de cizalladura que se encuentren ambas células en su trayectoria, aunque también es posible que las dos o ninguna se convierta en supercélula. 


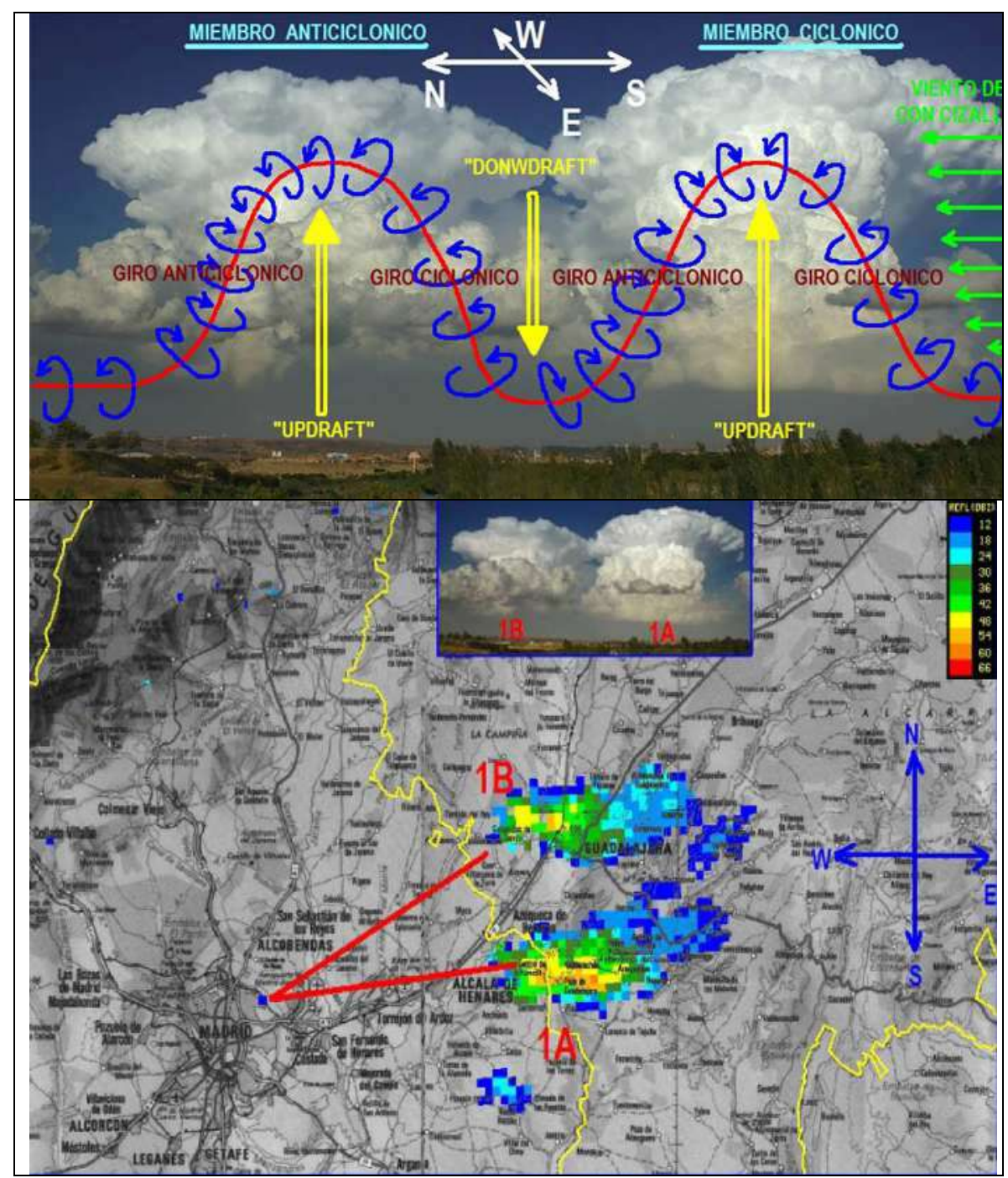

Figura 2.12. "Storm-splitting" en Madrid-Guadalajara. Arriba: flujos asociados.

Abajo: evolución de las dos tormentas vistas por el radar de Madrid Fuente: J. A. Quirantes, 2012 y AEMET.

\subsection{2.- Supercélulas: hodógrafas, tipos de vorticidad horizontal, helicidad, dinámica básica y desvíos}

\section{Hodógrafa}

Se ha visto como desencadenante el caso concreto de entorno inestable con cizalladura unidireccional (sin cambio de dirección en la vertical). Sin embargo en la naturaleza hay distintos tipos de perfiles verticales de variación del viento.

En este sentido, la hodógrafa es una herramienta gráfica que permite evaluar la cizalladura del viento. Viendo una hodógrafa nos podemos hacer una idea rápida de cómo varía el viento en la vertical de un lugar.

En un entorno convectivo resulta sumamente importante comprender la estructura de cizalladura vertical del viento para discriminar el tipo de convección que puede desarrollarse, el lugar donde pueden formarse nuevas tormentas, la probabilidad de que se formen tormentas supercelulares e incluso el movimiento de una tormenta 0 un sistema de tormentas.

Las supercélulas se forman en entornos de destacables valores de cizalladura vertical de viento, o sea en entornos con hodógrafas largas. Estas hodógrafas con frecuencia son curvas, aunque el ambiente favorable para supercélulas no lo requiere necesariamente.

- Hodógrafa recta: lleva a la generación de un storm splitting, con una célula ciclónica (derecha), y otra anticiclónica (izquierda). Climatológicamente en el hemisferio norte, aunque ambas células (o ninguna) pueden progresar a supercélula, es más probable que lo haga la célula ciclónica.

- Hodógrafas curvas: generación de una supercélula con giro ciclónico en casos de cizalladura clockwise (variación del viento con la altura en el mismo sentido del avance de las agujas del reloj), o de una supercélula con giro anticiclónico en casos de cizalladura counterclockwise (variación del viento con la altura en sentido opuesto al de avance de las agujas del reloj). 
El factor crucial para saber si una tormenta evolucionará o no a supercélula es el tipo de vorticidad horizontal que alimenta a la tormenta en su trayectoria.

De hecho una forma interesante de descomponer la vorticidad horizontal $\boldsymbol{\omega}_{\mathrm{h}}$ es en la dirección paralela a la velocidad relativa a la tormenta ( $\mathbf{v}-\mathbf{c})$, obteniéndose la llamada vorticidad streamwise, y en la normal a esa dirección, llamada vorticidad crosswise (figura 2.13).

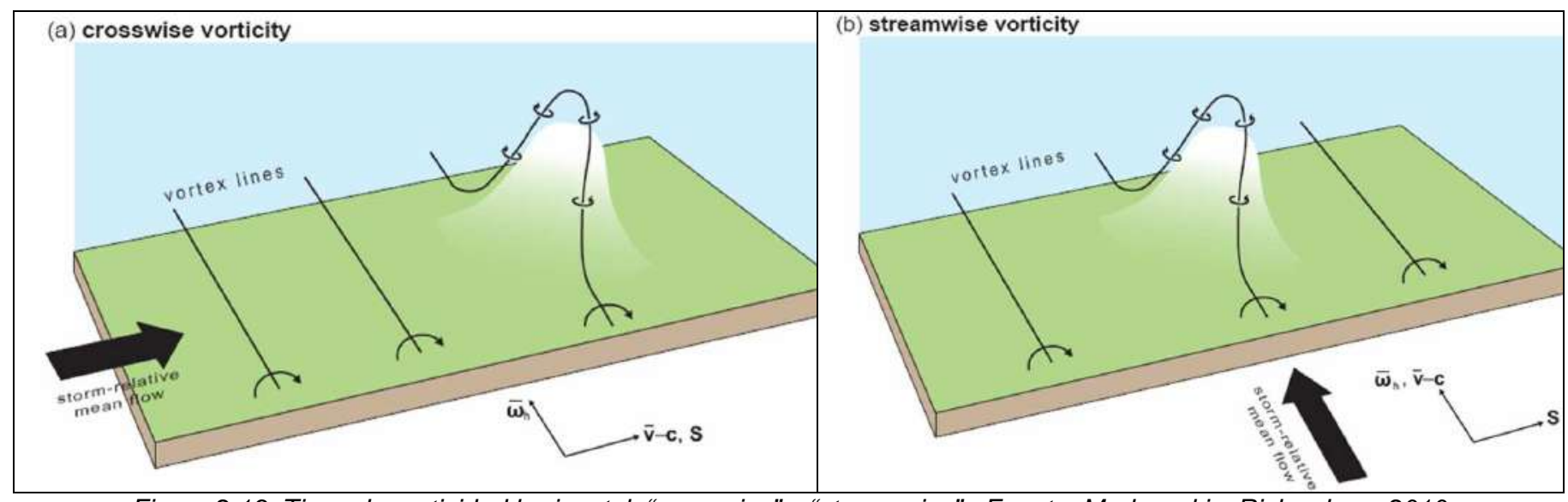

Figura 2.13. Tipos de vorticidad horizontal: "crosswise" y "streamwise". Fuente: Markowski y Richardson, 2010

La vorticidad streamwise es clave, pues, cuando aparece en una corriente ascendente, ésta adquiere una rotación vertical neta, diciéndose que el flujo es helicoidal o contiene helicidad relativa a la tormenta. Precisamente la helicidad relativa a la tormenta (Storm Relative Helicity) es el producto de la vorticidad streamwise y la velocidad relativa a la tormenta.

$$
S R H=\int_{0}^{h}\left(\mathbf{v}_{h}-\mathbf{c}\right) \cdot \omega_{h} d z
$$

Este parámetro de helicidad relativa a la tormenta es crucial en la dinámica supercelular. Normalmente se integra en toda la profundidad de la capa de alimentación en niveles bajos de la tormenta (usualmente los primeros $3 \mathrm{~km}$, aunque su valor es realmente variable en cada tormenta).

En resumen, las supercélulas se forman en entornos con importante cizalladura vertical en los primeros kilómetros, lo que genera vorticidad horizontal. A la vorticidad la podemos descomponer en dos componentes: vorticidad streamwise (paralela al flujo relativo que alimenta la tormenta en capas bajas), y vorticidad crosswise (perpendicular al flujo relativo que alimenta la tormenta). La magnitud que cuantifica esta disponibilidad del entorno para que se genere una supercélula es la helicidad relativa a la tormenta, y da una idea del valor de la componente streamwise de la vorticidad.

Dependiendo de cómo se oriente esta vorticidad respecto al flujo que alimenta la tormenta en capas bajas, y del perfil de cizalladura vertical existente, así será el tipo de la tormenta que se genere. Se presentan tres posibles casos, ver figura 2.14:

\section{Caso a: cizalladura vertical unidireccional y vorticidad crosswise.}

Predomina la vorticidad crosswise (perpendicular al flujo que alimenta la tormenta en niveles bajos), con cizalladura vertical unidireccional. Se formará un storm-splitting, una división de la tormenta en dos células simétricas, pero en la que ninguna de ellas posee una rotación neta en su corriente ascendente (updraft). Ambas se moverían separándose paulatinamente y debido a ese desvío alguna de las dos podrá adquirir posteriormente vorticidad streamwise y evolucionar a supercélula. En este caso, todavía no hay desvío (flecha amarilla hacia delante) o éste no es lo suficientemente intenso, por lo que aún no está correlacionada la velocidad relativa a la tormenta (v-c) con la vorticidad horizontal en niveles bajos $\boldsymbol{\omega}_{\mathrm{h}}$. Tampoco está correlacionada la vorticidad, una vez se ha puesto vertical $\boldsymbol{\omega}_{\mathrm{v}}$, con la velocidad vertical de la corriente ascendente $\mathbf{w}$. Ello da como resultado que los vórtices formados quedan situados a los lados de la corriente ascendente, no centrados con ella, por lo que no hay una rotación neta de la corriente ascendente. No es una supercélula. 


\section{Caso b: cizalladura vertical unidireccional y vorticidad streamwise adquirida por desvío.}

Una vez se desarrolla el storm-splitting, los dos miembros se separan progresivamente. Cuanto más se separen (más se desvíen), más posibilidades hay de convertirse en supercélula. En el caso b de la figura 2.14 se muestra solamente la separación del miembro de la derecha (flecha amarilla hacia un lado). Este miembro, el ciclónico, adquiere, por razón de este desvío, vorticidad streamwise, convirtiéndose posiblemente en una supercélula. En este caso, y a pesar de tratarse de un entorno con cizalladura unidireccional, si empieza a estar correlacionada la velocidad relativa a la tormenta $(\mathbf{v}-\mathbf{c})$ con la vorticidad horizontal en niveles bajos $\boldsymbol{\omega}_{\mathrm{h}}$ y también se correlacionan la vorticidad vertical $\boldsymbol{\omega}_{\mathrm{v}}$ con la velocidad vertical de la corriente ascendente $\mathbf{w}$. De igual manera ocurriría con el miembro anticiclónico, aunque las posibilidades de convertirse en supercélula suelen ser menores debido a que, climatológicamente, en el hemisferio norte el perfil de viento favorece el desarrollo de las supercélulas ciclónicas. En el hemisferio sur ocurriría justamente lo contrario.

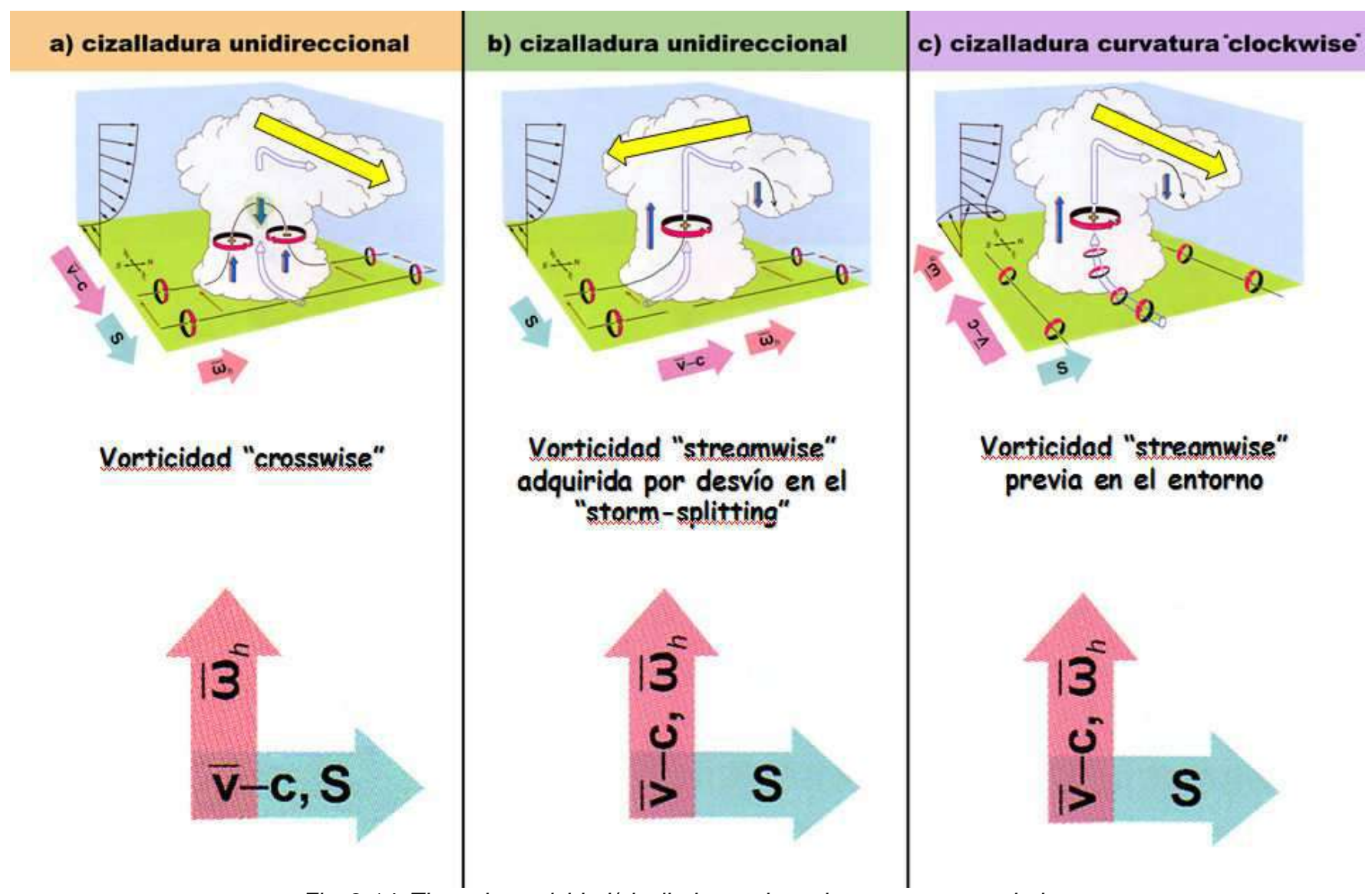

Fig. 2.14. Tipos de vorticidad/cizalladura y tipos de tormentas asociados. Flecha amarilla gruesa marca el movimiento de la tormenta. Flecha blanca, flujo que alimenta la tormenta.

La "S" muestra en los tres casos el vector cizalladura. Fuente: Markowski y Richardson (adaptadas).

\section{Caso c: cizalladura vertical direccional y vorticidad streamwise previa en el entorno.}

Predomina en el entorno la vorticidad streamwise (paralela al flujo alimentador), con cizalladura vertical direccional. Se generará una supercélula con una updraft que presentará rotación neta sin necesidad de que se produzca previamente un storm-splitting. En este caso, si está correlacionada la velocidad relativa a la tormenta $(\mathbf{v}-\mathbf{c})$ con la vorticidad horizontal en niveles bajos $\boldsymbol{\omega}_{\mathrm{h}}$ y también se correlacionan la vorticidad vertical $\boldsymbol{\omega}_{\mathbf{v}}$ con la velocidad vertical de la corriente ascendente w (más aún que en el caso anterior), por lo que la rotación será más intensa. El resultado es que el vórtice generado en niveles medios es concéntrico con el centro de la updraft, generándose un flujo helicoidal en la corriente ascendente. Si la cizalladura direccional fuera del tipo counterclockwise se formaría una supercélula anticiclónica. Obsérvese en la figura como el tamaño del vórtice dibujado en niveles medios representa una vorticidad/rotación mayor en los casos b y c que en el caso a. 


\section{Dinámica básica de una supercélula}

La creación del mesociclón implica la existencia de rotación (vorticidad vertical) en una capa de varios kilómetros de espesor, con un máximo en niveles medios. Dicho máximo situado en medio de la corriente ascendente está directamente relacionado con el máximo de velocidad ascensional.

La vorticidad vertical crea un máximo de presión que provoca una perturbación dinámica de presión de abajo hacia arriba, lo que hace que desde las capas medias se aspire aire procedente de los niveles inferiores, el cual, asciende en forma helicoidal. Esta fuerza ascensional incrementa la intensidad de la corriente (updraft), inicialmente debida a la inestabilidad atmosférica. Por otra parte y debido a la variación vertical del vector cizalladura, en cada nivel se genera otra perturbación horizontal de presión que hará que la corriente ascendente se regenere continuamente y se desvíe hacia un lado dependiendo de las características propias del entorno de la tormenta.

\section{Desvíos de las supercélulas}

Debido a causas dinámicas comentadas, las supercélulas se desvían (propagan) respecto a la trayectoria marcada por el viento medio rector en capas medias.

- Las supercélulas ciclónicas (en el hemisferio norte, H.N.), con variación vertical de viento con la altura en el sentido de las agujas del reloj, se desvían hacia la derecha del viento medio (más propiamente del vector cizalladura media), y se llaman right moving supercells.

- Las supercélulas anticiclónicas (H.N.), con variación vertical de viento con la altura en sentido contrario al de las agujas del reloj, se desvían hacia la izquierda (más propiamente del vector cizalladura media), y se llaman left moving supercells. resultante.

La figura 2.15 es un resumen del tipo de cizalladura, y por tanto de la hodógrafa, y la clase de estructura

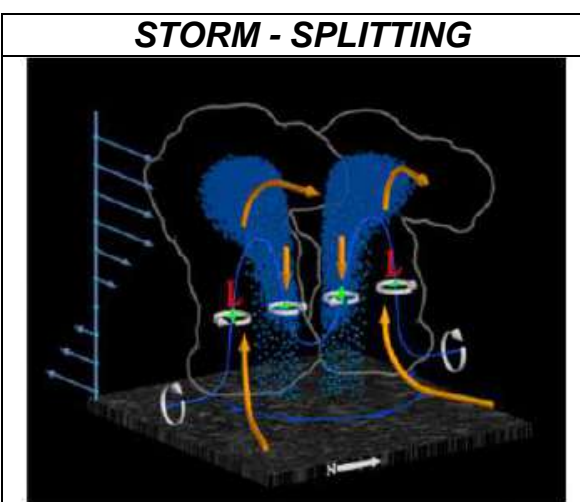

CASO DE CIZALLADURA UNIDIRECCIONAL

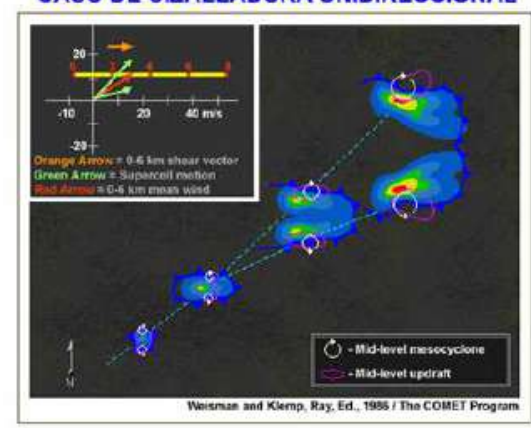

\section{SUPERCELULA CICLÓNICA}

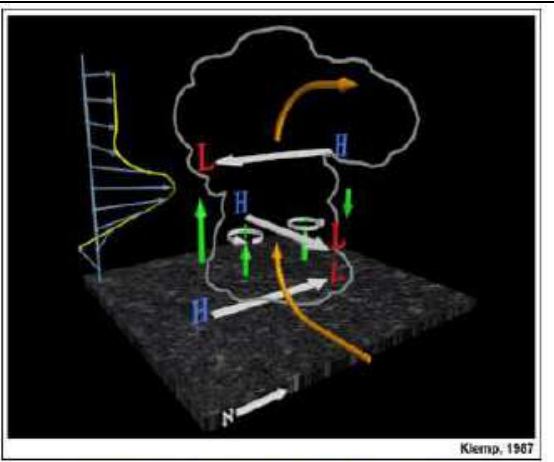

CASO DE CIZALLADURA "CLOCKWISE"
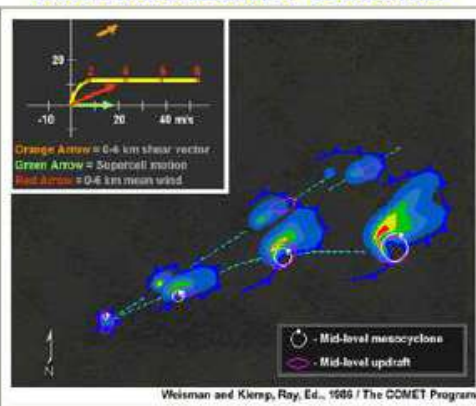

\section{SUPERCELULA ANTICICLONICA}

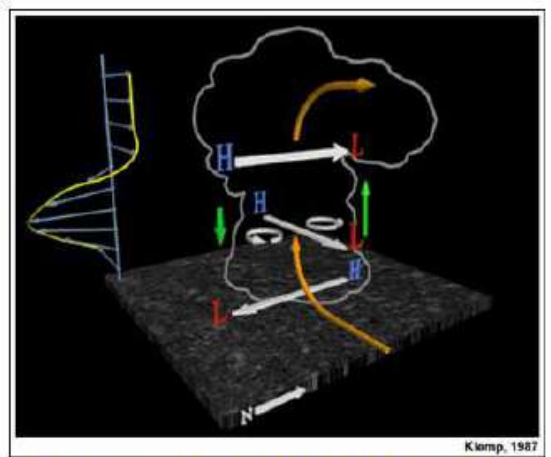

CASO DE CIZALLADURA "COUNTERCLOCKWISE"

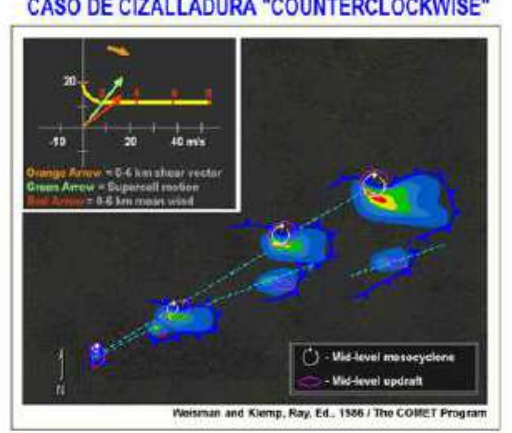

Figura 2.15. Tipos de cizalladura y estructuras convectivas resultantes. Fuente: The Comet Program y Weisman and Klemp 


\subsection{3.- Estructura y fases de las supercélulas}

Esquemáticamente en la figura 2.16 podemos visualizar la estructura de una supercélula en capas bajas, donde las líneas de corriente son relativas al suelo. En rojo se representa el borde de la zona de ecos que mostraría el radar.

Existe una amplia zona de ecos, corriente abajo, con flujo divergente, representando la corriente descendente del flanco delantero (FFD: Forward Flank Downdraft)

Hay otra zona de descensos en la parte trasera, que rodea a la circulación ciclónica en niveles medios y que puede producir una estructura en forma de gancho. Es la corriente descendente del flanco trasero (RFD: Rear Flank Downdraft).

Dos microfrentes de racha, uno del flanco trasero (rear flank gust front) debido a la precipitación del flanco trasero que canaliza al flujo que alimenta a la célula en niveles bajos, formándose una columna de aire ascendente muy marcada, y otro asociado al flanco delantero.

En amarillo se encuentra la zona de la corriente ascendente giratoria (UpDraft)

La tornadogénesis suele ubicarse con más probabilidad en el área próxima al gancho de reflectividad radar, donde existe mayor cizalladura y gradiente de reflectividad. Se denota con una "T" en la figura 2.16. No obstante, sólo en un pequeño porcentaje de supercélulas se producen tornados.

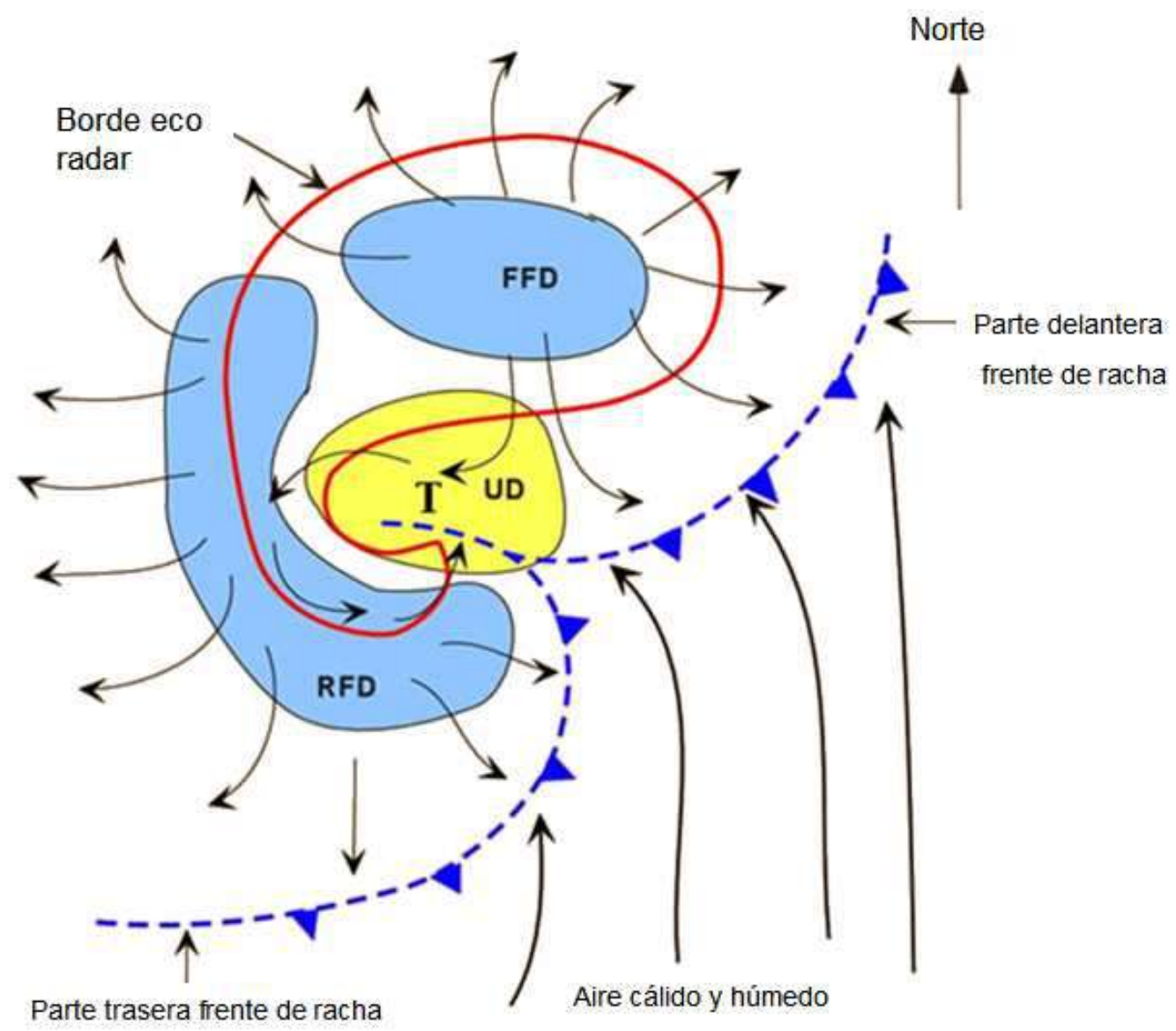

Figura 2.16. Estructura de una supercélula vista desde arriba. Fuente: Lemon y Doswell, 1979 
Seguidamente, y haciendo uso de la figura 2.17, se comentan las principales características básicas y duración orientativa y aproximada de cada fase del ciclo de vida simplificado para una supercélula típica de unas 2 horas de duración. Algunos de los elementos que se describen serán detallados más adelante a lo largo de este documento.

Fase Inicial (30 minutos)

Se origina la corriente ascendente (UpDraft) en rotación que termina formando un mesociclón. Es observable la nube llamada "inflow cloud".

Fase de Desarrollo (aparición del mesociclón) (30 minutos)

En esta fase está presente el UpDraft/mesociclón y se forma la FFD (corriente descendente del flanco delantero). Se desarrolla el frente de racha de la FFD.

Fase de Madurez (60 minutos)

Se forma, además, la RFD (corriente descendente del flanco trasero). Coexisten UpDraft/mesociclón, FFD y RFD en retroalimentación y estado cuasi-estacionario. Aquí surgen, en niveles bajos, los siguientes elementos nubosos más característicos de una supercélula: "wall cloud", "tail cloud" y "beaver tail".

Fase de Colapso (30 minutos)

Se desarrolla el frente de racha de la RFD. Surge el clear-slot. Una parte de la RFD llamada occlusion downdraft, ocluye a la UpDraft. La FFD y RFD forman una única corriente descendente (downdraft) y la UpDraft desaparece o vuelve a regenerarse (mesociclogénesis). En esta fase de colapso puede aparecer un tornado.
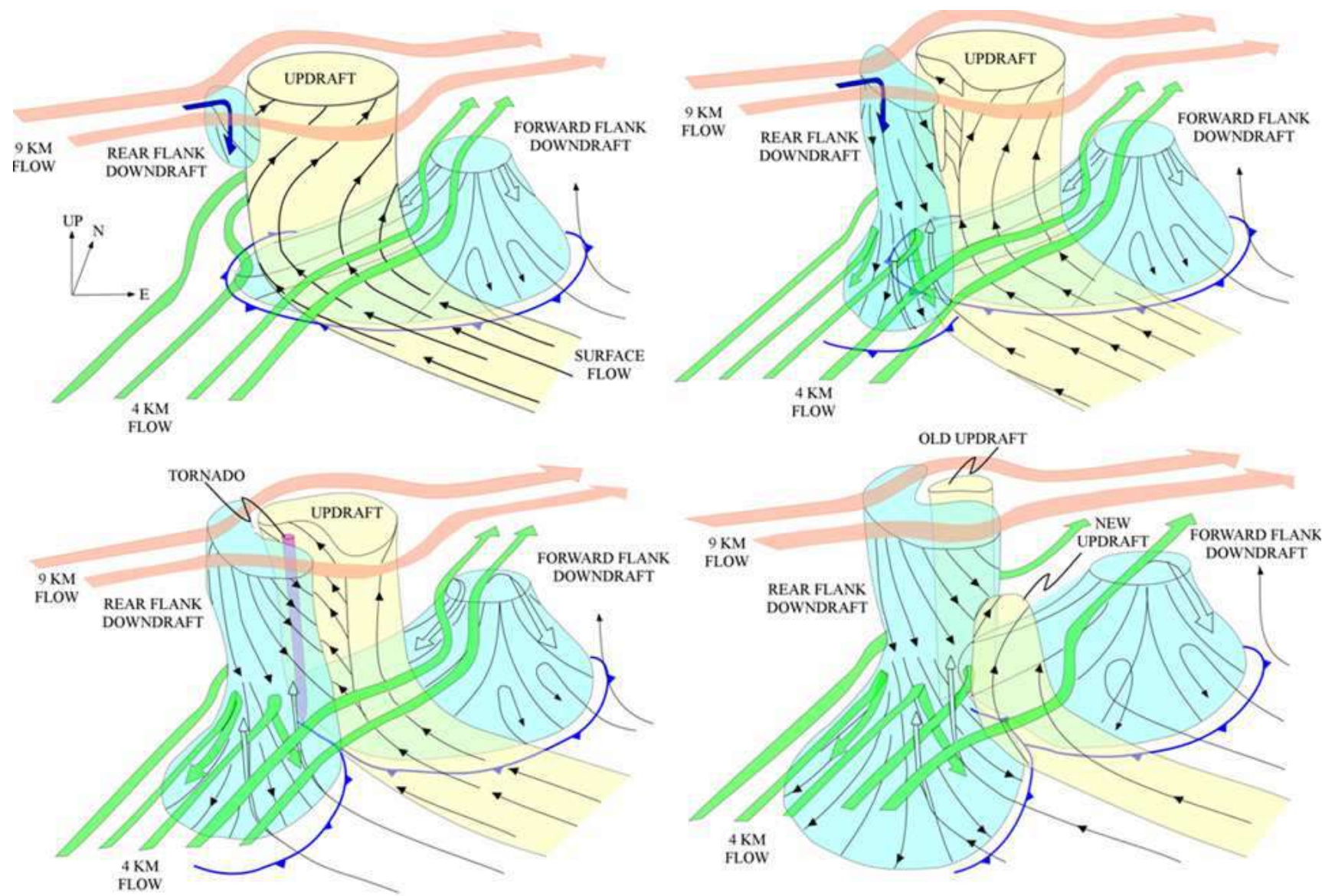

Figura 2.17. Circulaciones mesoescalares en las distintas fases de una supercélula. Fuente: Lemon y Doswell, 1979 


\section{3.- Supercélulas en España: identificación y dificultades en su catalogación}

En este apartado se describen las principales características de las supercélulas en España y los entornos favorables para su formación.

\section{1.- Entornos supercelulares en España}

La física asociada a las supercélulas es la misma en España que en la zona de las Llanuras de Estados Unidos que es donde, en general, se desarrollan y observan las supercélulas más violentas en la Tierra. Por tanto, la existencia de una corriente giratoria ascendente y persistente es tan cierto en las supercélulas españolas como en las americanas. La diferencia es que en España rara vez se encuentran entornos meteorológicos favorables a la formación de supercélulas con valores tan elevados de energía potencial convectiva disponible (CAPE) como en Estados Unidos. Aparte, otros parámetros clave (como la cizalladura vertical o la helicidad relativa a la tormenta) también presentan valores bastante más bajos que los típicos de Norteamérica en entornos supercelulares.

Pero los patrones observacionales y elementos de las nubes supercelulares, tanto a simple vista como en radar, son análogos en las americanas y las españolas. En general, los mesociclones en España suelen ser más pequeños, horizontal y verticalmente, que los clásicos de Estados Unidos, y por tanto presentan giros menos intensos y con ciclos de vida de menor duración. No obstante, una importante severidad sigue estando presente, prácticamente siempre, en cualquier tipo de supercélula. Como consecuencia en España los parámetros ambientales toman en general valores menores que en Norteamérica y por ello las rotaciones mesociclónicas son a la par menos intensas y duraderas. En cualquier caso, los entornos meteorológicos favorables a la formación de supercélulas deben ser siempre proclives a la organización de la convección, es decir, existencia de elevados valores de cizalladura vertical del viento en los primeros kilómetros de la vertical. Se ha constatado que en España las supercélulas superan ciertos valores umbrales (de manera aproximada) propios de nuestro territorio, y en muchas ocasiones alejados de los valores bibliográficos de referencia propios de las supercélulas de Estados Unidos.

Así, muchas de las supercélulas en España superan determinados umbrales en variables consideradas clave en los entornos supercelulares, como SBCAPE (Surface Based CAPE: Energía potencial convectiva desde superficie), CIZ6 (cizalladura en los seis primeros kilómetros) y $S R H 3$ (helicidad relativa a la tormenta en los tres primeros kilómetros). Aunque no es estrictamente necesario, en no pocas situaciones los ambientes en los que se desarrolla una supercélula en España superan simultánea y respectivamente los valores de $200 \mathrm{~J} / \mathrm{kg}, 9 \mathrm{~m} / \mathrm{s}$ y 100 $\mathrm{m}^{2} / \mathrm{s}^{2}$ para las citadas variables.

Pero hay que hacer una importante salvedad. A veces los modelos (o sondeos próximos) marcan una SRH3 significativamente inferior al mencionado valor umbral, pudiéndose formar también supercélulas cuando concurran valores suficientemente apropiados de inestabilidad y cizalladura. Esto es así porque existen mecanismos que generan un incremento importante de helicidad relativa a la tormenta a una escala que no es bien simulada por los modelos o porque éstos no utilizan los últimos métodos optimizados de cálculo del desvío pronosticado de la tormenta (método de Bunkers). De hecho los modelos no representan adecuadamente elementos que influyen decisivamente en el movimiento (intensidad y dirección) de la tormenta, tales como fronteras locales (frentes, líneas secas, orografía local, etc.). Por tanto variaciones provocadas por los citados factores pueden hacer variar radicalmente los valores locales de $S R H$ y hacerlos muy distintos de los del entorno. Precisamente en el experimento VORTEX realizado en Estados Unidos (Markowski et al., 1998) se comprobó la gran variabilidad espacio temporal de la helicidad relativa a la tormenta, variable clave en la génesis supercelular. También suele ser preferible no usar un estrato vertical fijo para calcular la helicidad, sino lo que se denomina la capa efectiva, variable en cada caso, que es en la que se alimenta la tormenta.

Además, hay que tener en cuenta que en ciertas ocasiones, sin existir una SRH3 significativa o directamente con valores de $S R H 3$ próximos a cero, se forman también supercélulas en cualquier parte del mundo, siempre que haya una gran CIZ6 (cizalladura vertical unidireccional de los primeros $6 \mathrm{~km}$ ) y un SBCAPE equilibrados. En estos entornos se producen "Storm-Splittings" que en ocasiones, como se explicó en el capítulo 2 (figura 2.14) pueden terminar generando una supercélula.

Aunque los umbrales no deben ser tenidos en cuenta de manera estricta, sí pueden servir como referencia orientativa de entornos bastante favorables al desarrollo supercelular, especialmente si los modelos prevén una significativa superación de los valores presentados. Lo anterior no es óbice para que haya casos en que los modelos por ejemplo sean incapaces de simular alguna de dichas variables, y por ejemplo infraestimen de manera grave el valor local real de la helicidad relativa a la tormenta. 
A su vez, dentro de los entornos generales de supercélulas en España, podemos encontrar dos subvariedades bien diferenciadas.

- HSLC (High Shear Low CAPE). En estos casos hay gran cizalladura (ClZ6 $>9 \mathrm{~m} / \mathrm{s})$ y CAPE pequeño ( $S B C A P E<500 \mathrm{~J} / \mathrm{kg}$ aproximadamente). En esta categoría se pueden distinguir dos clases:

- Supercélulas con convección profunda pero con CAPE "reducido".

- Minisupercélulas, generalmente más típicas de época fría, con tropopausa baja y escaso desarrollo vertical aunque gran cizalladura.

- HSHC (High Shear High CAPE). Son las supercélulas de gran cizalladura y elevado CAPE, o sea las que más se parecen, salvando las distancias, a las típicas de Estados Unidos.

Oficialmente no existe un cómputo anual de supercélulas en España. Sin embargo existen estadísticas oficiosas, como por ejemplo la del subforo de "Tiempo Severo" de Meteored, confeccionada por un numeroso grupo de cazatormentas durante los últimos diez años, que sostiene que se vienen produciendo durante cada año unas 100 posibles supercélulas sobre zona terrestre en España, de ellas unas 40 supercélulas confirmadas y otras 60 presuntas supercélulas, debido a que en algunos casos es muy difícil establecer con certeza el tipo de estructura convectiva o bien no se dispone de su confirmación objetiva por medio del producto radar de viento Doppler. Esta cifra vendría a corroborar que las supercélulas no son estructuras tormentosas demasiado raras. No obstante hay que hacer la salvedad de que la mayoría de ellas no poseen la intensidad, severidad y espectacular apariencia de las originadas en los Estados Unidos. También de esa estadística no oficial, y en primera aproximación, se podría inferir que, aproximadamente, un 30\% de los casos de supercélulas ocurridas en España provienen de un storm-splitting.

Sin embargo las supercélulas, en general, son muy eficientes a la hora de ocasionar tiempo severo en España, tal como granizo mayor de $2 \mathrm{~cm}$ de diámetro, y/o rachas de viento $>100 \mathrm{~km} / \mathrm{h}$ y/o tornados. Lo más usual son vientos fuertes y granizo grande, ya que es poco frecuente la aparición de tornados asociados a supercélulas. En cuanto a la precipitación, suele ser en general bastante intensa al paso de la supercélula (excepto en algunos casos de supercélulas $L P$ ). Sin embargo si el paso de la supercélula es rápido las precipitaciones pueden ser muy intensas pero de corta duración, registrándose toda la cantidad de agua recogida en unas pocas decenas de minutos. Por el contrario las supercélulas tipo HP que se mueven de manera lenta son muy peligrosas ya que pueden totalizar grandes cantidades de precipitación y causar graves inundaciones. Por último, hay que mencionar que normalmente las supercélulas presentan un importante aparato eléctrico, fundamentalmente constituido por descargas intranube, casi continuas, que configuran un "rumor" mantenido de truenos, característico de las supercélulas. También se producen intensos rayos nube-tierra de polaridad positiva, que caen desde gran altura, sobre todo en la interface entre la updraft y la FFD.

\section{2.- Morfología básica de una supercélula a simple vista}

En primer lugar hay que recordar la gran cantidad de giros observables en las nubes, de distintas escalas, intensidades y duraciones, que no tienen nada que ver con la presencia mesociclónica ligada indefectiblemente a la existencia supercelular. Por tanto, hay ocasiones en que ciertos patrones observacionales nos pueden llevar a dudar sobre si lo que estamos viendo puede ser una supercélula o no, especialmente si el observador no es una persona experimentada en la identificación de estructuras supercelulares.

Por otra parte, en los casos de supercélulas, las condiciones ambientales atmosféricas deben ser proclives a la convección organizada y ricas en helicidad. En este sentido habrá muchos días en que podemos descartar la generación de supercélulas.

Como ya se ha comentado, la clave en la identificación supercelular es la observación de un giro mesoescalar de cierta profundidad, a escala de la tormenta y con una duración de al menos unos 20 minutos. En bastantes ocasiones la visualización posterior de una animación filmada mediante la técnica time-lapse, que permite imprimirle más velocidad a la animación, es muy útil para poder detectar todavía de una manera todavía más precisa el giro solidario, extenso y persistente del mesociclón.

Hay más patrones típicamente atribuibles a las supercélulas cuya visualización nos indica que con alta probabilidad estamos ante una supercélula. No obstante hay situaciones complejas que nos impiden disponer de una buena perspectiva, o bien existen impedimentos visuales que no permiten identificar las características típicas debido a la propia precipitación intensa o bien a nubes u otros obstáculos interpuestos. 
Desde luego, una combinación entre la observación visual y la exploración a partir de imágenes de un radar Doppler puede resultar muy conveniente para confirmar categóricamente o afirmar con alta fiabilidad el avistamiento de una supercélula.

En la figura 3.1 podemos ver algunos de los patrones visuales característicos de las supercélulas, que se irán posteriormente describiendo, aunque cada tormenta supercelular puede presentar una morfología con sus propias variantes y particularidades, aparte de los condicionantes relativos inherentes a la posición del observador respecto a la tormenta.

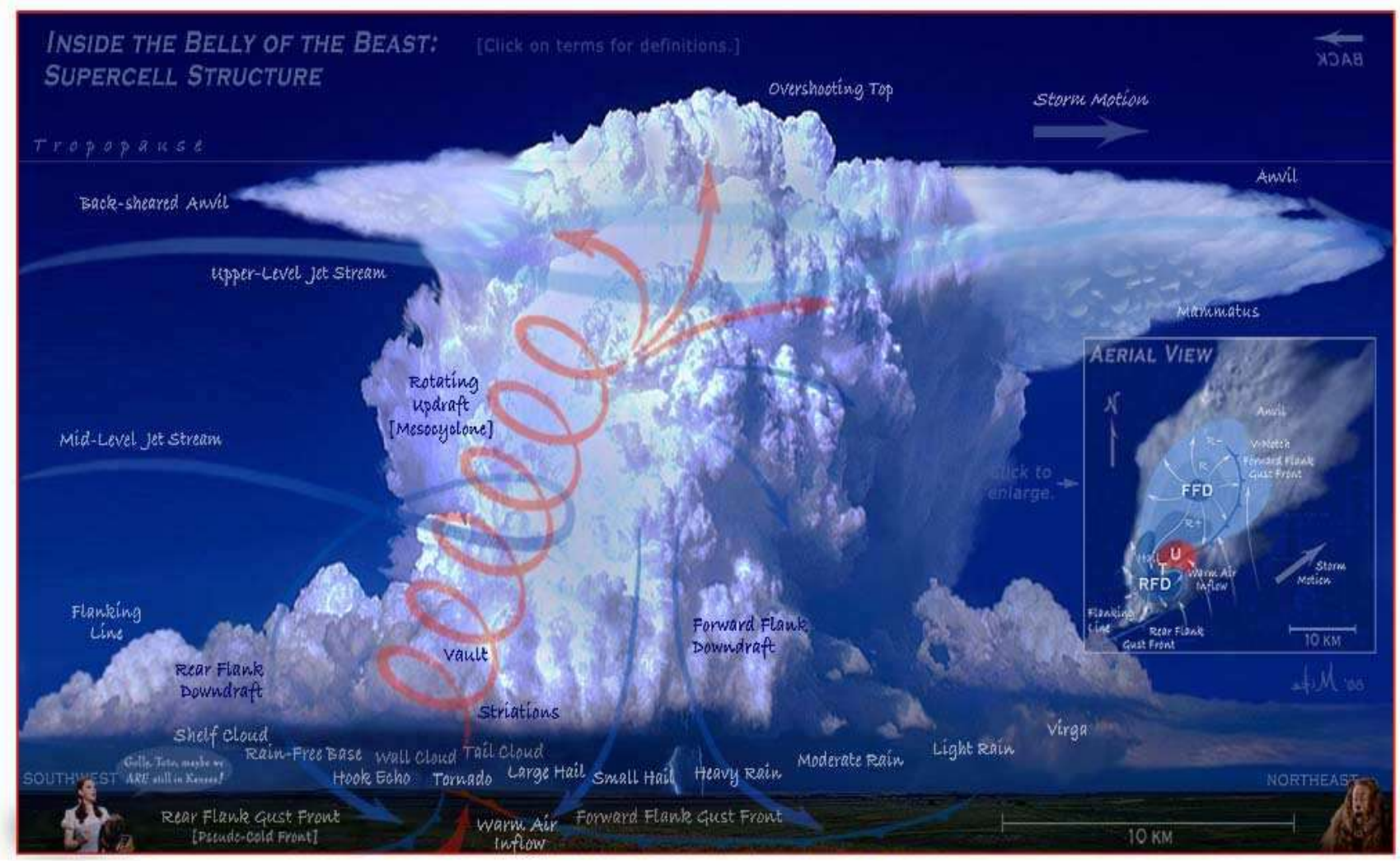

Figura 3.1. Circulaciones y morfología de una supercélula. Fuente: $\underline{\text { http://www.cobaltocumulus.com/supercell.html }}$

Al divisar una supercélula en su fase de madurez desde una posición idónea (zona coloreada de verde en la figura 3.3 para una supercélula ciclónica en el hemisferio norte), deberíamos poder en muchos casos distinguir las corrientes descendentes de los flancos delantero y trasero (FFD: Forward Flank Downdraft y RFD: Rear Flank Downdraft), así como la corriente con ascenso helicoidal (Updraft), tal y como se muestra en la figura 3.2. Concretamente deberíamos poder observar:

- Una rotación persistente en gran parte de la corriente ascendente (mesociclón), que es la zona que queda situada por encima de la base circular libre de lluvia. Esta rotación puede afectar solamente a los niveles medios de la updfraft o también, además, a los niveles bajos. No siempre la rotación es visible a simple vista.

- Una corriente descendente principal de precipitación en el flanco delantero de la tormenta $(F F D)$, quedando ésta última totalmente separada (desacoplada) de la corriente ascendente en rotación. Esta zona es donde se suelen producir más descargas eléctricas.

- Una zona trasera de descenso $(R F D)$, que es una región de aire seco que afecta a la parte de atrás de la circulación de la tormenta. Suele estar acompañada de una zona concentrada y reducida de precipitación que parece surgir desde debajo de la updfraft, aunque realmente está "abrazándola" alrededor suyo.

Una rotación fuerte favorece la intensificación de la corriente ascendente, la persistencia y la organización de toda la estructura supercelular (figura 3.4). Asimismo, la temperatura y la humedad en la zona de descenso del flanco trasero $(R F D)$ juegan un papel decisivo en la posible formación de un tornado mesociclónico, el cual se produce tan sólo en un pequeño porcentaje de supercélulas. El tiempo severo que acompaña a las supercélulas puede ser: granizo grande y posible precipitación muy intensa justo al lado de la zona de ascenso, granizo de menor tamaño y precipitación de menor intensidad en zonas más alejadas de la corriente de ascenso, vientos descendentes intensos sobre todo en la parte trasera, asociados al $R F D$, y en ocasiones un tornado. 


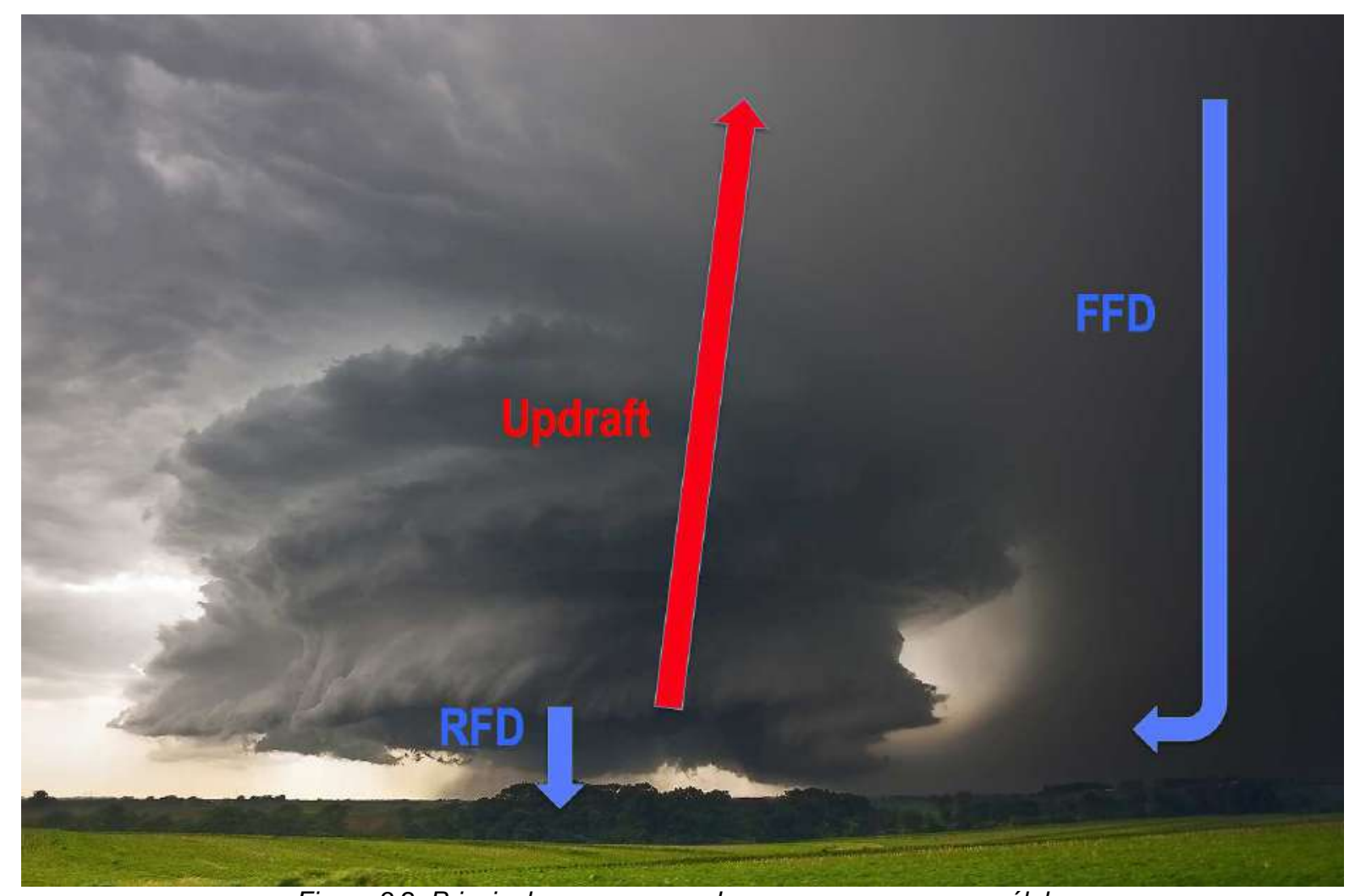

Figura 3.2. Principales ascensos y descensos en una supercélula.

Corriente ascendente en rotación, updraft/mesociclón en color rojo.

Corrientes descendentes FFD y RFD en color azul.

Foto (C) Mike Hollingshead

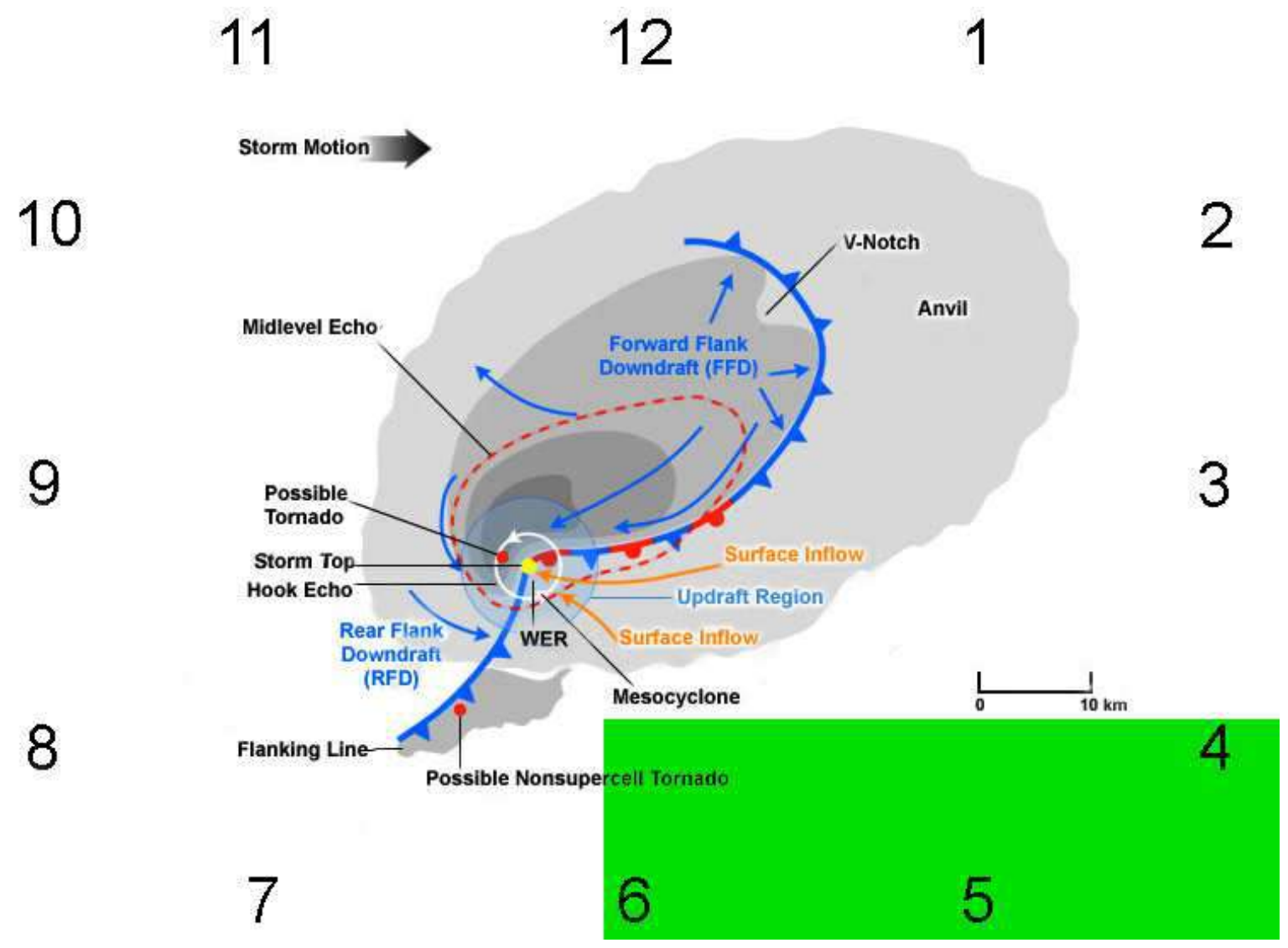

Figura 3.3. En color verde zona de visualización idónea para un observador que quiere identificar las principales características morfológicas de una supercélula ciclónica en el hemisferio norte que se mueve de "8" a "2". 


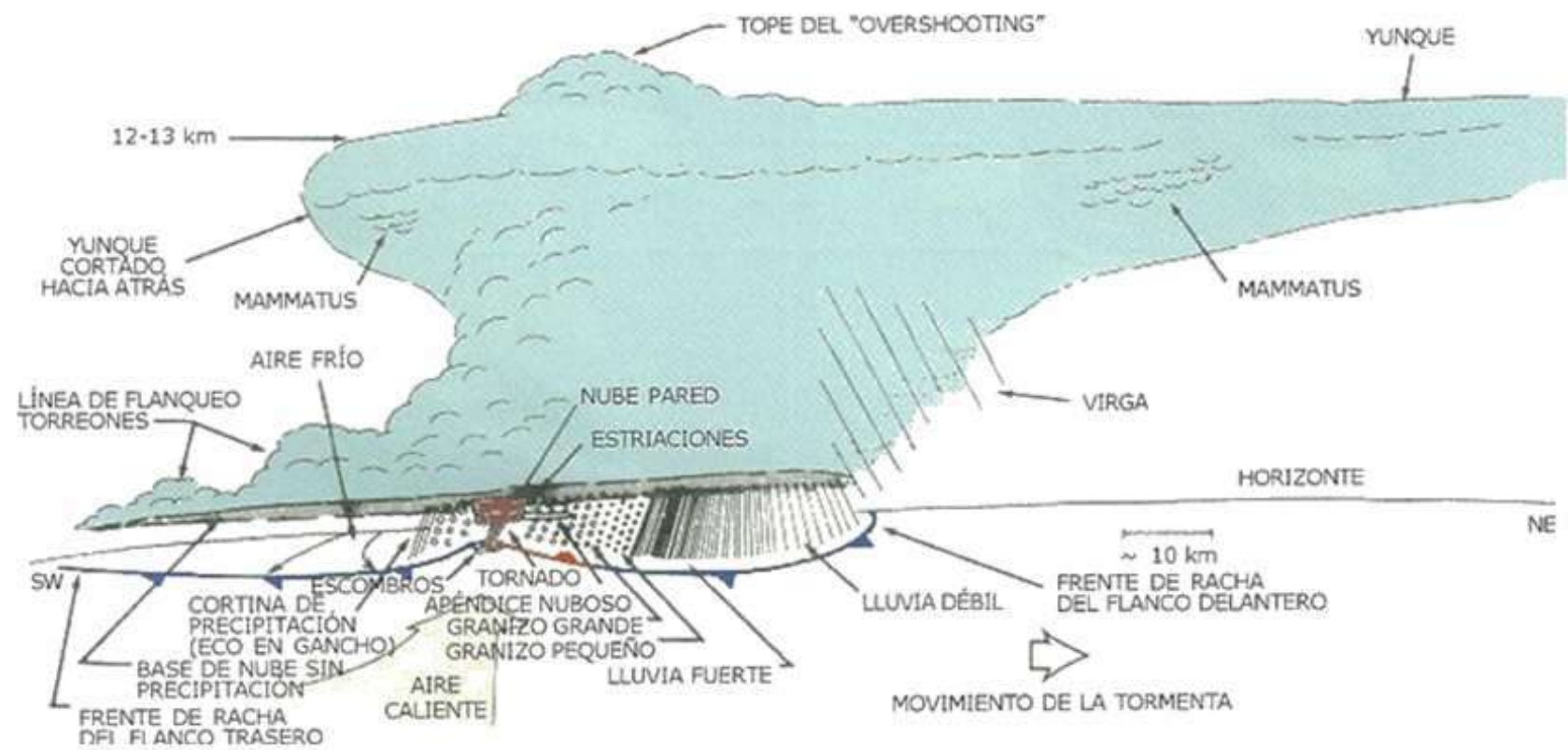

Figura 3.4. Esquema de una supercélula. Adaptación de imagen del National Severe Storms Laboratory del NWS.

Veremos a continuación algunos elementos muy característicos y significativos, siguiendo un orden aproximadamente de arriba abajo en el esquema de la figura anterior.

Vista desde lejos, podremos identificar la torre tormentosa principal, que es en realidad la representación de la corriente ascendente desde su base próxima al suelo hasta el tope nuboso. Esta torre principal puede presentar las siguientes propiedades:

- Bordes bien definidos.

- Apariencia de coliflor.

- Rotación visible en niveles medios y/o bajos y posible presencia de estrías en las nubes, síntoma de la rotación existente (a veces cuesta apreciar esta rotación a simple vista).

Otro elemento diferenciador es que el yunque aparece más denso (yunque masivo) (figura 3.5), que en los típicos cumulonimbos y con una disposición hacia atrás en su parte trasera (back-sheared anvil), en oposición al flujo en niveles altos (figura 3.6). De este yunque masivo suelen colgar nubes tipo mammatus (figura 3.8), mucho más densas y numerosas que en los Cumulonimbos típicos, apareciendo tanto en la parte trasera del yunque como en la delantera.

El overshooting o torreón (figura 3.7) suele ser bien identificado si nos encontramos suficientemente lejos de la tormenta, sobresaliendo entre 1 y $3 \mathrm{~km}$ por encima del propio yunque, siendo posible su intrusión en la estratosfera.

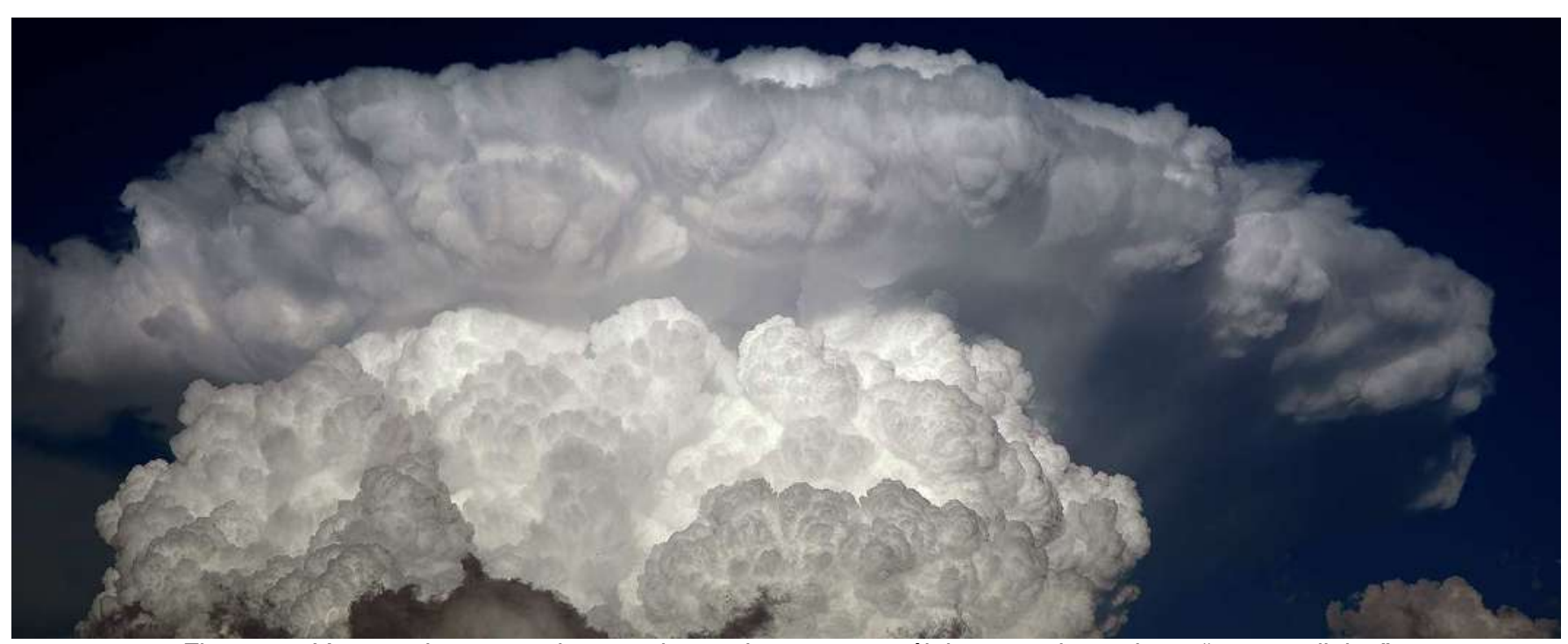

Figura 3.5 Yunque denso, masivo, en el tope de una supercélula proveniente de un "storm-splitting", Madrid-Guadalajara, 7 de Septiembre de 2004. Foto J.A. Quirantes. 


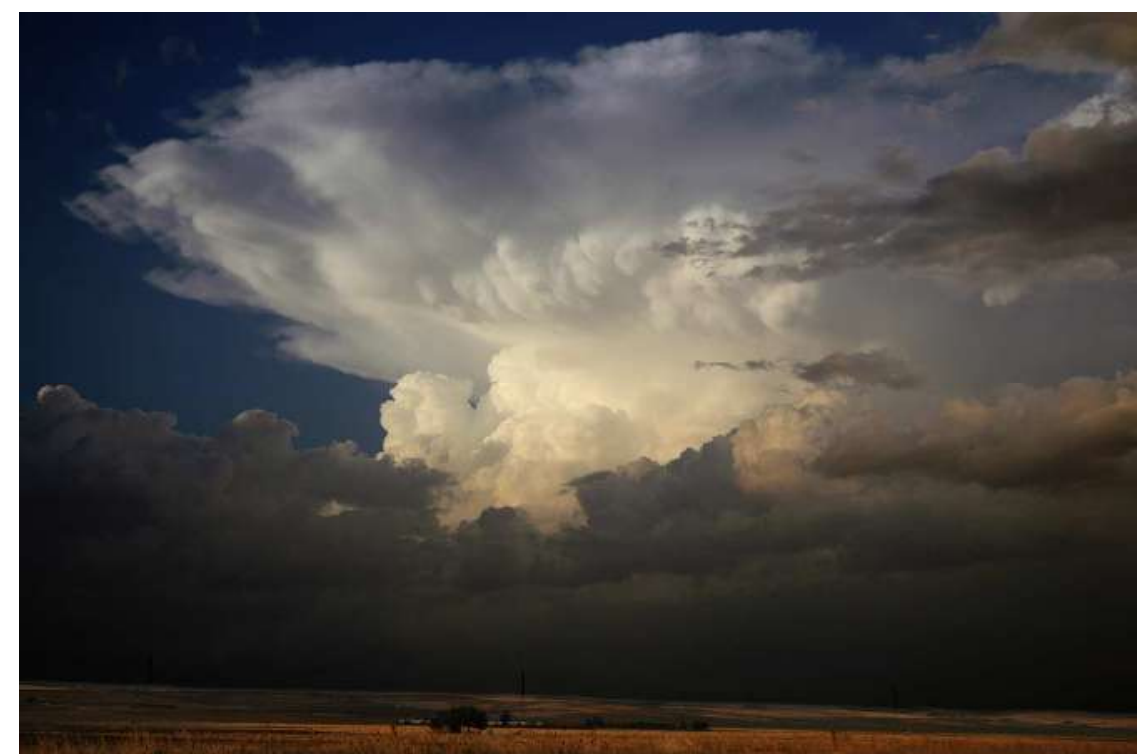

Figura 3.6 Yunque extendiéndose hacia atrás en la parte trasera de la supercélula. Foto J.A. Quirantes.

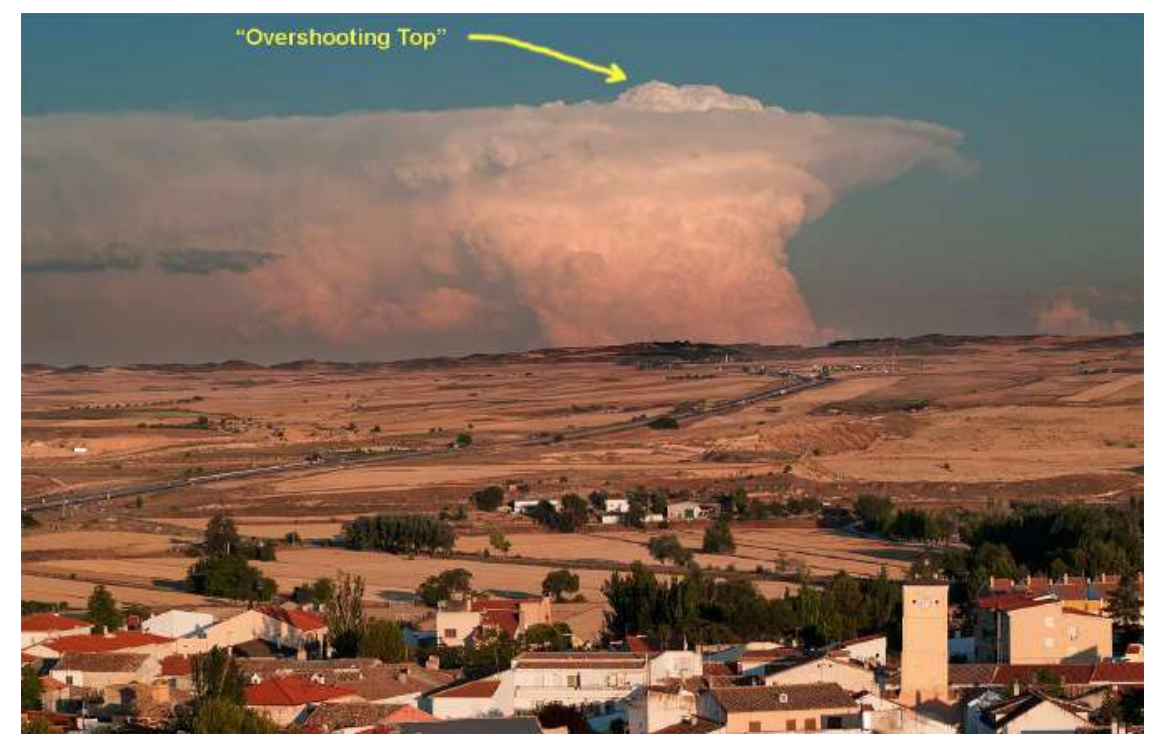

Figura 3.7 "Overshooting" sobresaliendo por encima del yunque de una supercélula Foto (c) Alberto Lunas Arias.

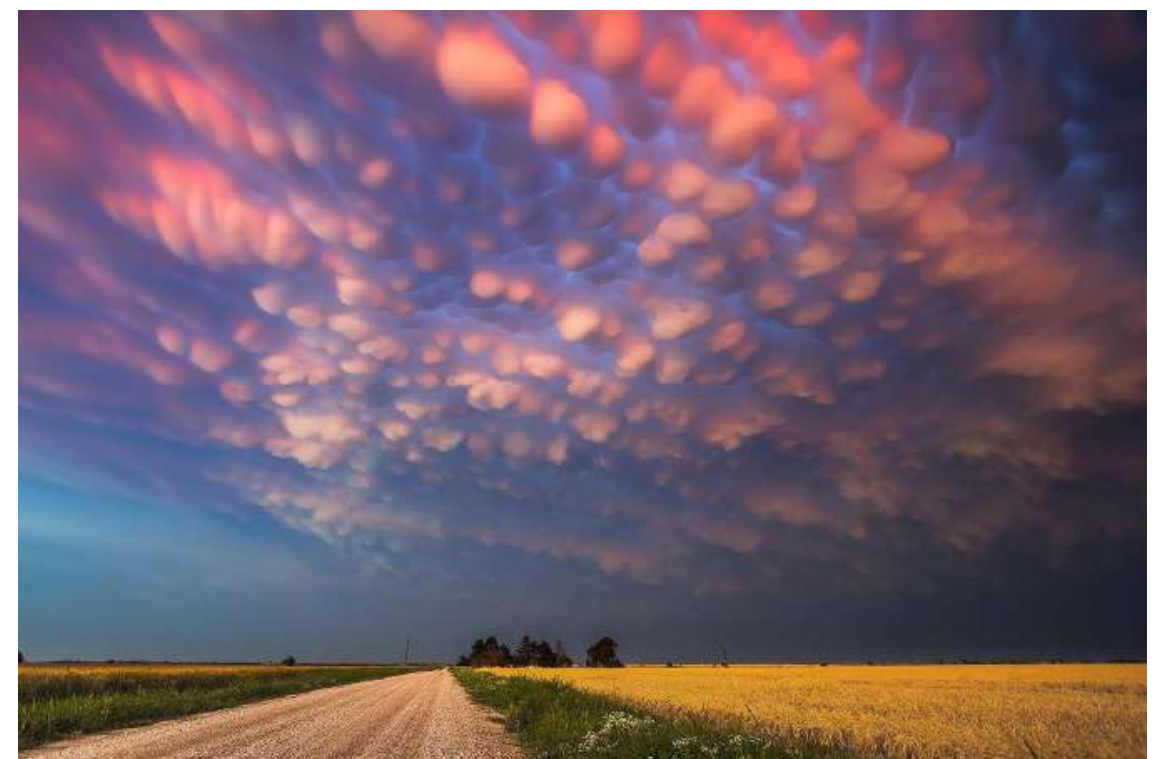

Figura 3.8 Mammatus asociados al yunque de una supercélula. Foto (C) Mike Hollingshead. 
La estructura de una tormenta supercelular muestra comúnmente un conjunto de estrías o bandas en los bordes de la nube confiriéndole un aspecto de sacacorchos (corkscrew) indicativo del giro mesoescalar, o en forma de estriaciones curvadas de manera similar a las rayas de los postes de los antiguos barberos (barber pole). Estas estrías y bandas no son otra cosa que la manifestación del giro de la corriente ascendente. Este giro debe ser solidario, mesoescalar y duradero. Ver figuras 3.9 y 3.10.

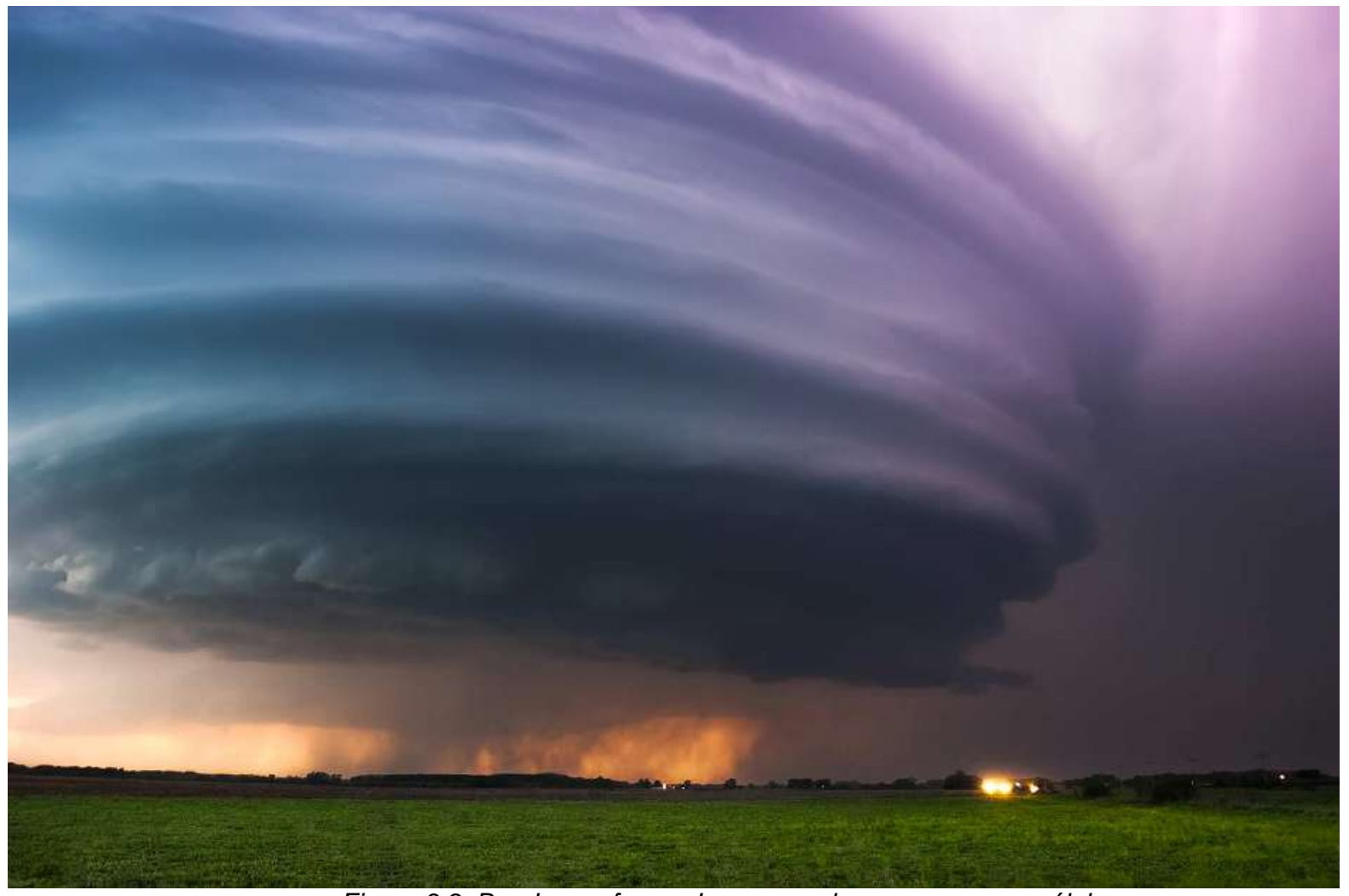

Figura 3.9. Bandas en forma de sacacorchos en una supercélula.

A la derecha se sitúa la FFD y en la zona central-izquierda una más pequeña RFD. Foto (C) Mike Hollingshead.

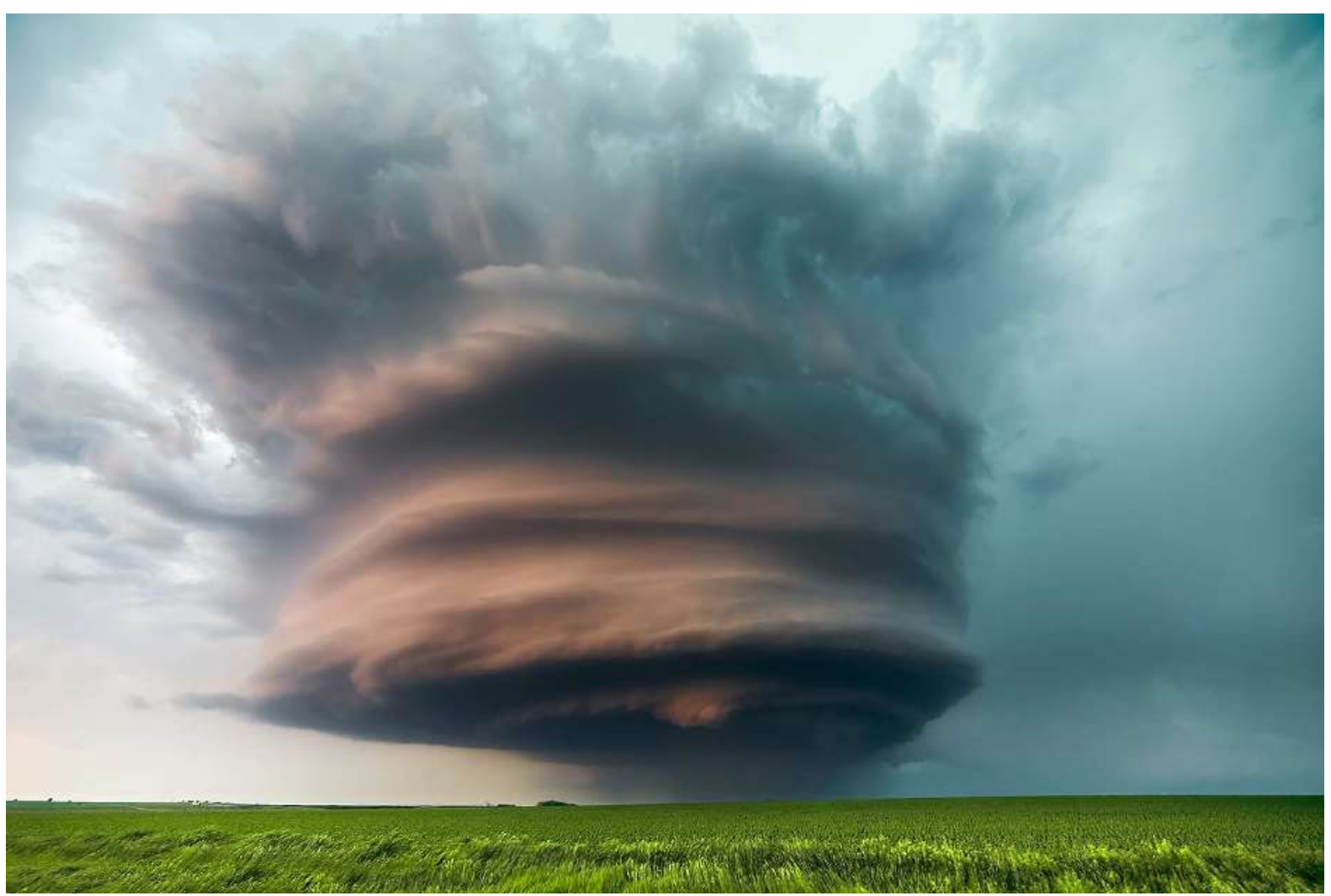

Figura 3.10. Bandas en forma de sacacorchos en una supercélula muestran gran parte del mesociclón. A la derecha se sitúa la FFD y en la zona central, detrás del mesociclón, la RFD.

Foto (c) Mike Hollingshead. 
Otro elemento destacable es la presencia de una base circular libre de precipitación (rain-free base) que es precisamente la base de la corriente ascendente en rotación (mesociclón) que sostiene precipitación y granizo sin que caigan al suelo en esta zona (figura 3.11).

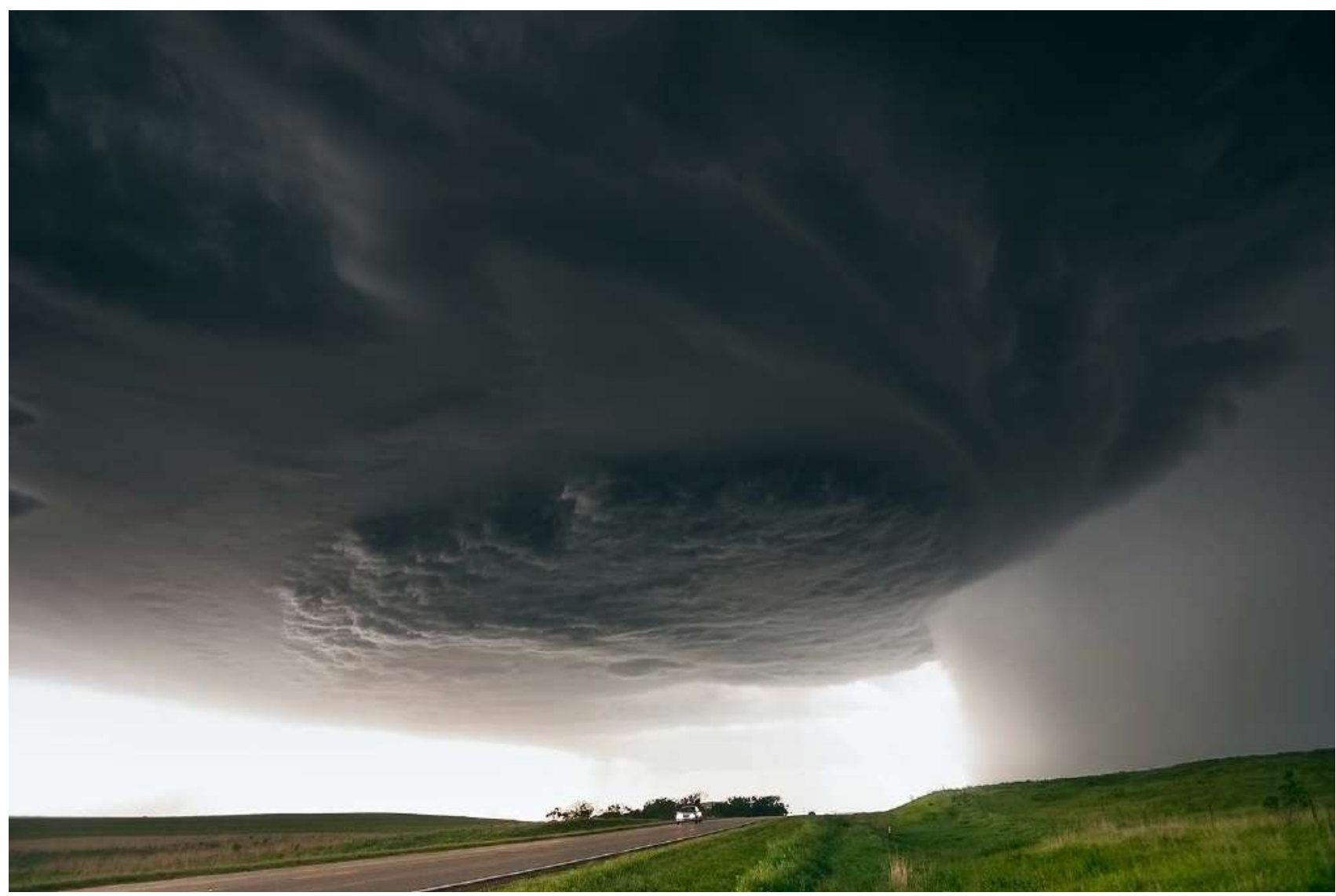

Figura 3.11 Base circular libre de precipitación, es la base de la corriente ascendente o mesociclón. A la derecha, totalmente separada (desacoplada), la corriente descendente del flanco delantero, FFD. Foto (C) Mike Hollingshead.

De esta base libre de precipitación suele colgar hacia abajo una nube pared (wall cloud), figuras 3.12 y 3.13, en forma de pezuña de caballo, frecuentemente en rotación. No obstante hay que tener en cuenta que podemos ver un wall cloud incluso en estructuras no severas, por lo que el hecho de ver un wall cloud no significa estar ante una supercélula.

El wall cloud en una supercélula se origina como consecuencia de la condensación del flujo de aire saliente de la corriente descendente del flanco delantero de la tormenta (FFD) y que de nuevo vuelve a ingestarse en la corriente ascendente de la supercélula, aspirado por el intenso mesociclón que se ha desarrollado en los niveles medios. El wall-cloud, por tanto, no se forma hasta un tiempo después de haber comenzado la intensa precipitación en la FFD. Por ejemplo, en la figura 3.11 todavía no se ha formado un wall-cloud. Al tratarse de aire más frío y húmedo que el del entorno que alimenta la tormenta, la condensación se produce a un nivel más bajo que éste.

En algunas ocasiones y según la perspectiva, el wall cloud puede no observarse al quedar oculta tras una zona de precipitación, especialmente en las supercélulas $H P$.

Cuando la rotación del mesociclón se propaga a los niveles más bajos, el wall cloud también rota y se desarrolla en su zona superior una estructura circular conocida como collar cloud. Por tanto la observación de un wall cloud persistente y giratorio es un elemento bastante determinante a la hora de considerar supercélula a una estructura tormentosa observada.

La zona del wall cloud es precisamente el lugar donde posteriormente, en la fase de colapso, se podría desarrollar un tornado. 


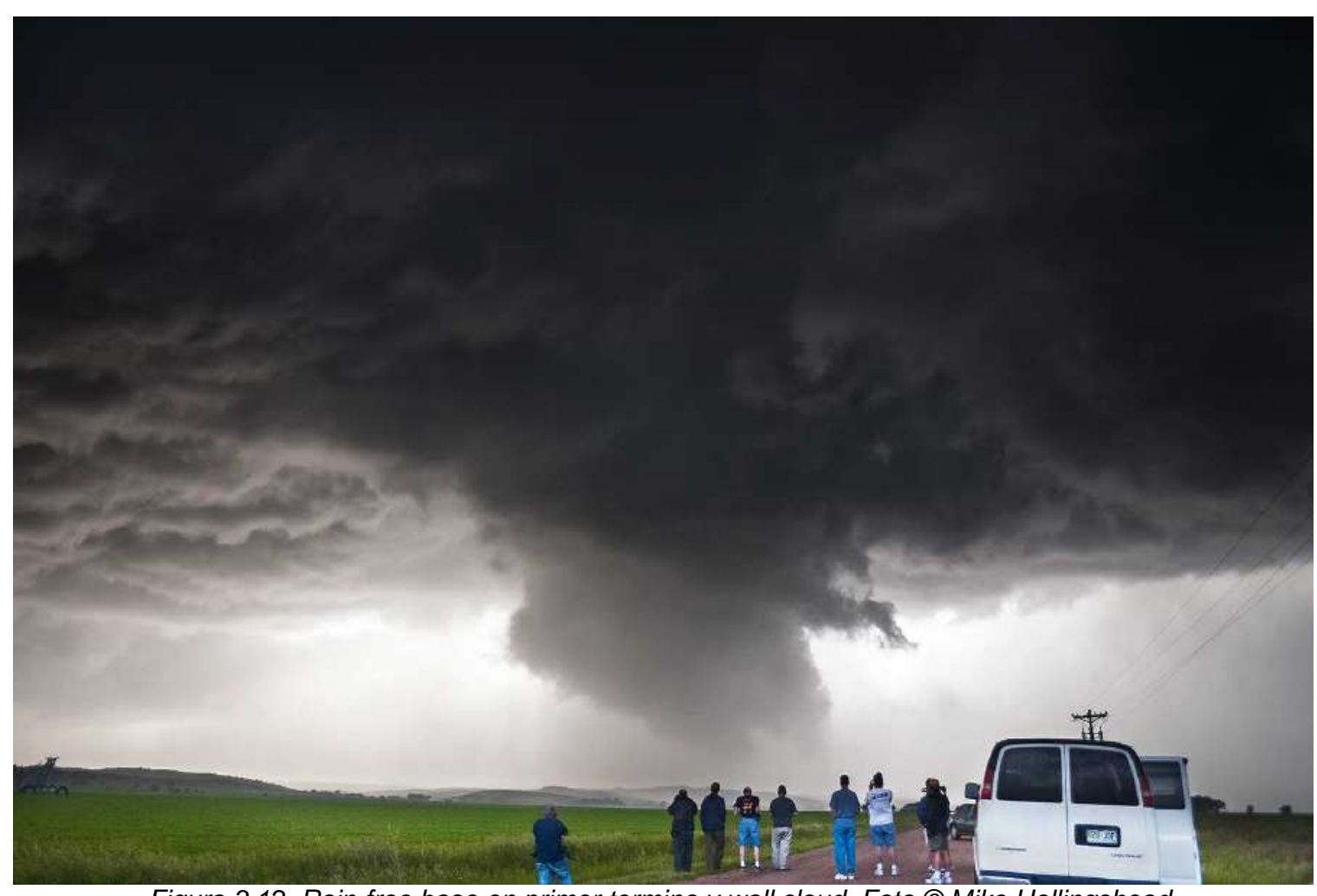

Figura 3.12. Rain-free base en primer termino y wall cloud. Foto @C Mike Hollingshead.

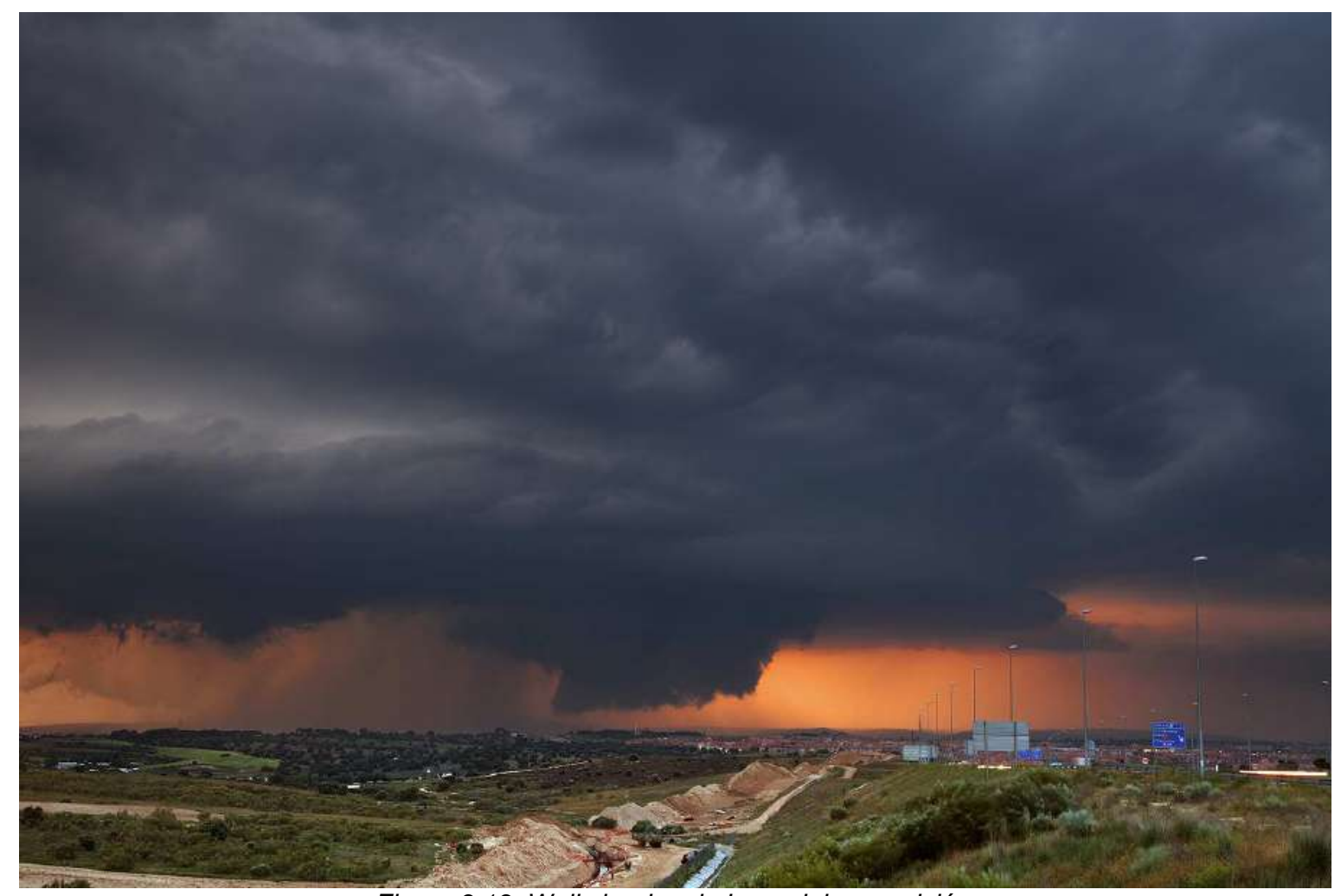

Figura 3.13. Wall cloud en la base del mesociclón.

A su izquierda, RFD. En el borde derecho, asoma parte de la FFD.

Supercélula en Madrid, 6 de Mayo de 2011. Foto J.A. Quirantes.

Asimismo, existen otros elementos característicos, que son bandas de entrada de aire cálido húmedo alimentador. La alimentación del flujo en niveles bajos, caracterizada por poseer una significativa vorticidad streamwise, es visible a partir de una nube llamada inflow cloud, que suele observarse sobre todo en la fase inicial de la supercélula. 
Normalmente, en la zona frontera entre la corriente descendente del flanco delantero $(F F D)$ y el wall cloud surge una nube en forma de cola, llamada tail cloud (figuras 3.14 y 3.15). Esta nube, que en la mayoría de las ocasiones parece surgir del suelo, tiene la particularidad de estar situada siempre en una zona lateral del wall cloud, orientada por el flujo proveniente de la FFD en capas bajas.

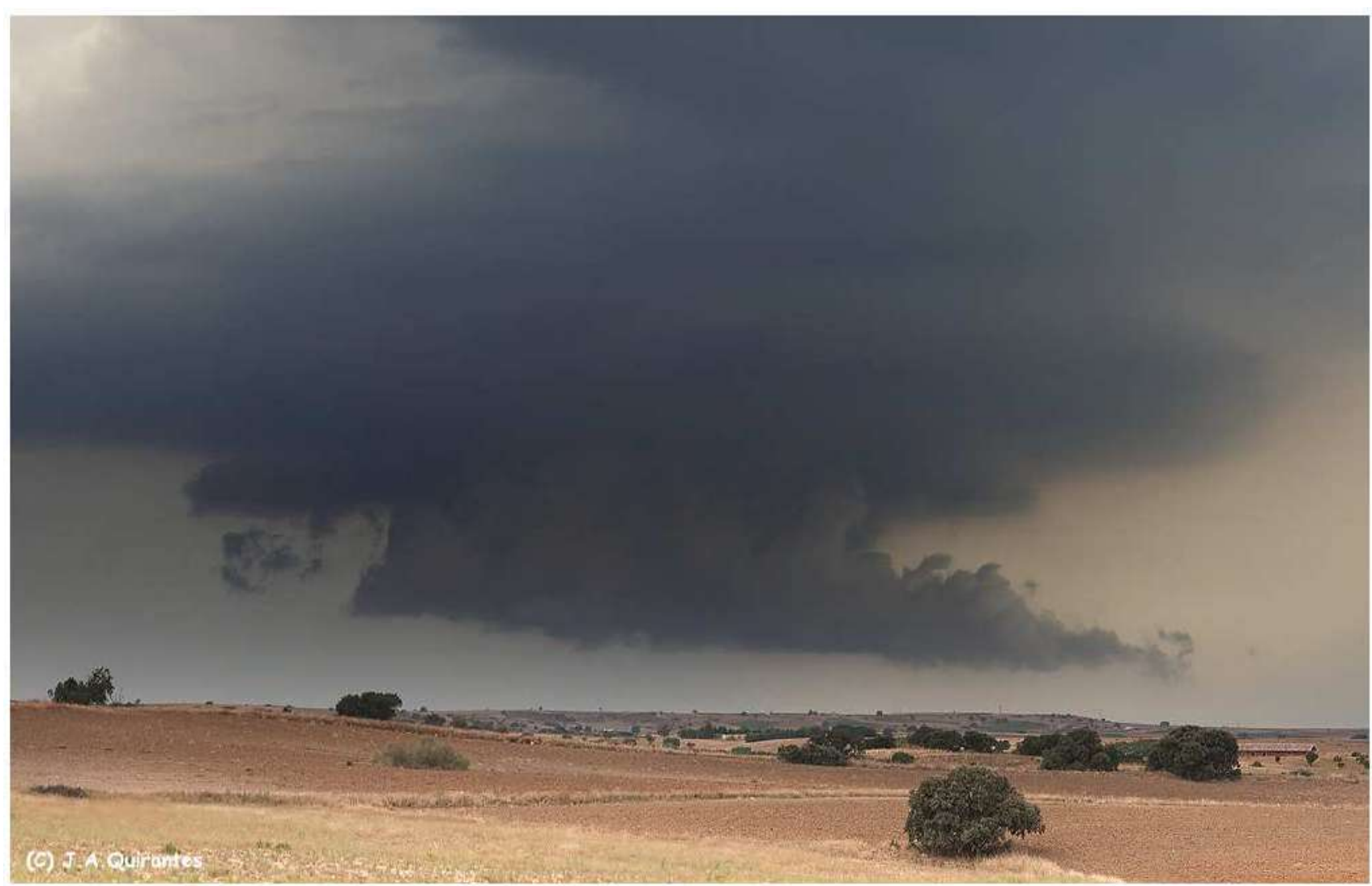

Figura 3.14. Tail cloud. Supercélula en Maqueda (Toledo), 1 de Septiembre de 2010. @ J.A.Quirantes.

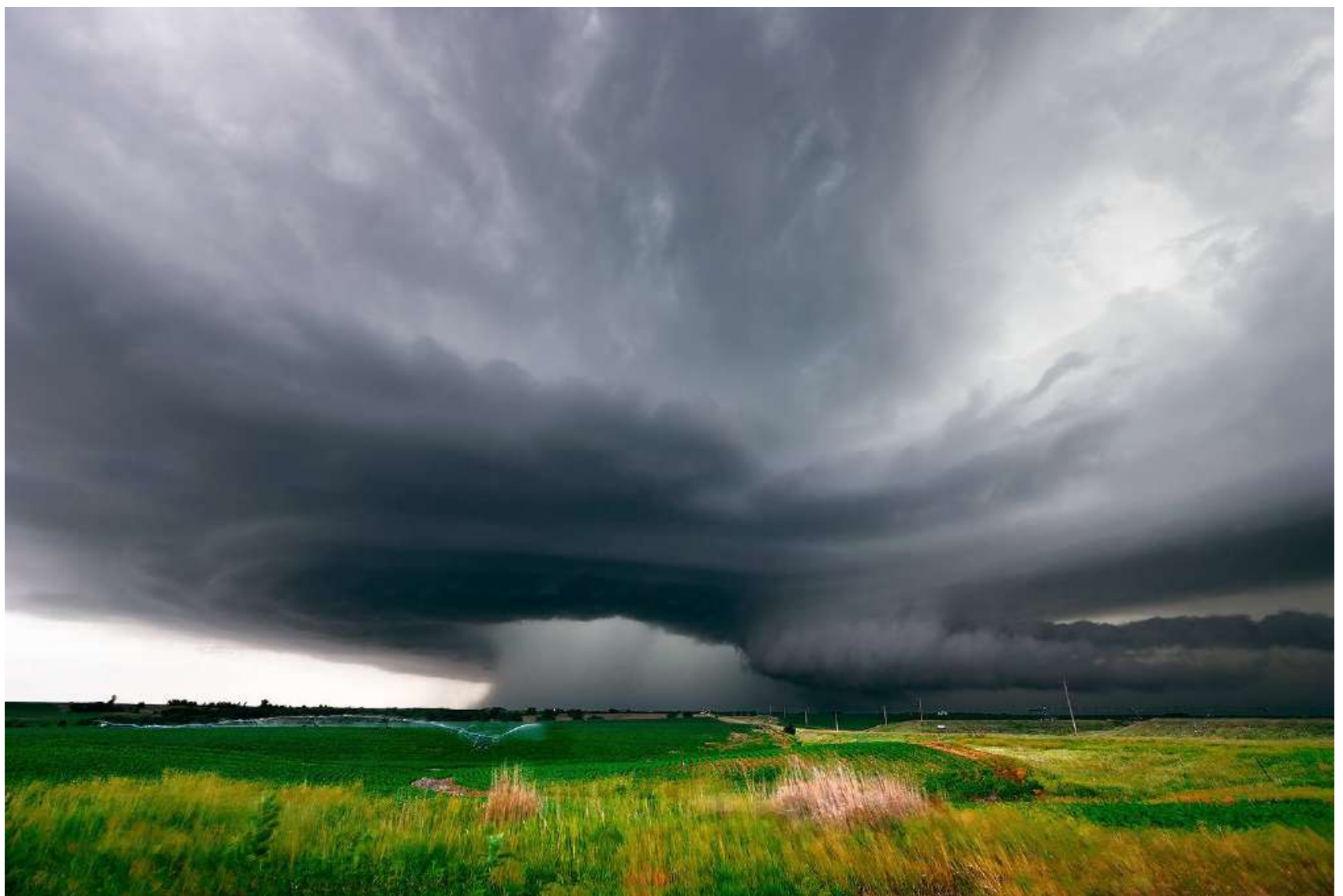

Figura 3.15. Tail cloud de considerable longitud a la derecha. La supercélula está en fase de colapso y el mesociclón (en el centro) está siendo ocluido por una intensa RFD. Foto @ Mike Hollingshead. 
La tail cloud está dispuesta de tal manera que se sitúa cerca de, o apunta hacia, la zona de precipitación principal (FFD); mientras que en el lado opuesto se situaría siempre, en caso de producirse, el tornado, como puede observarse en las figuras 3.16 y 3.17. Esta tail-cloud parece ser la manifestación de una alimentación de flujo secundaria con un suplemento extra de vorticidad streamwise y es una prueba patente de la retroalimentación común en las supercélulas, en este caso entre la FFD y el mesociclón. La tail cloud es una de las características visuales más exclusivas de las supercélulas.

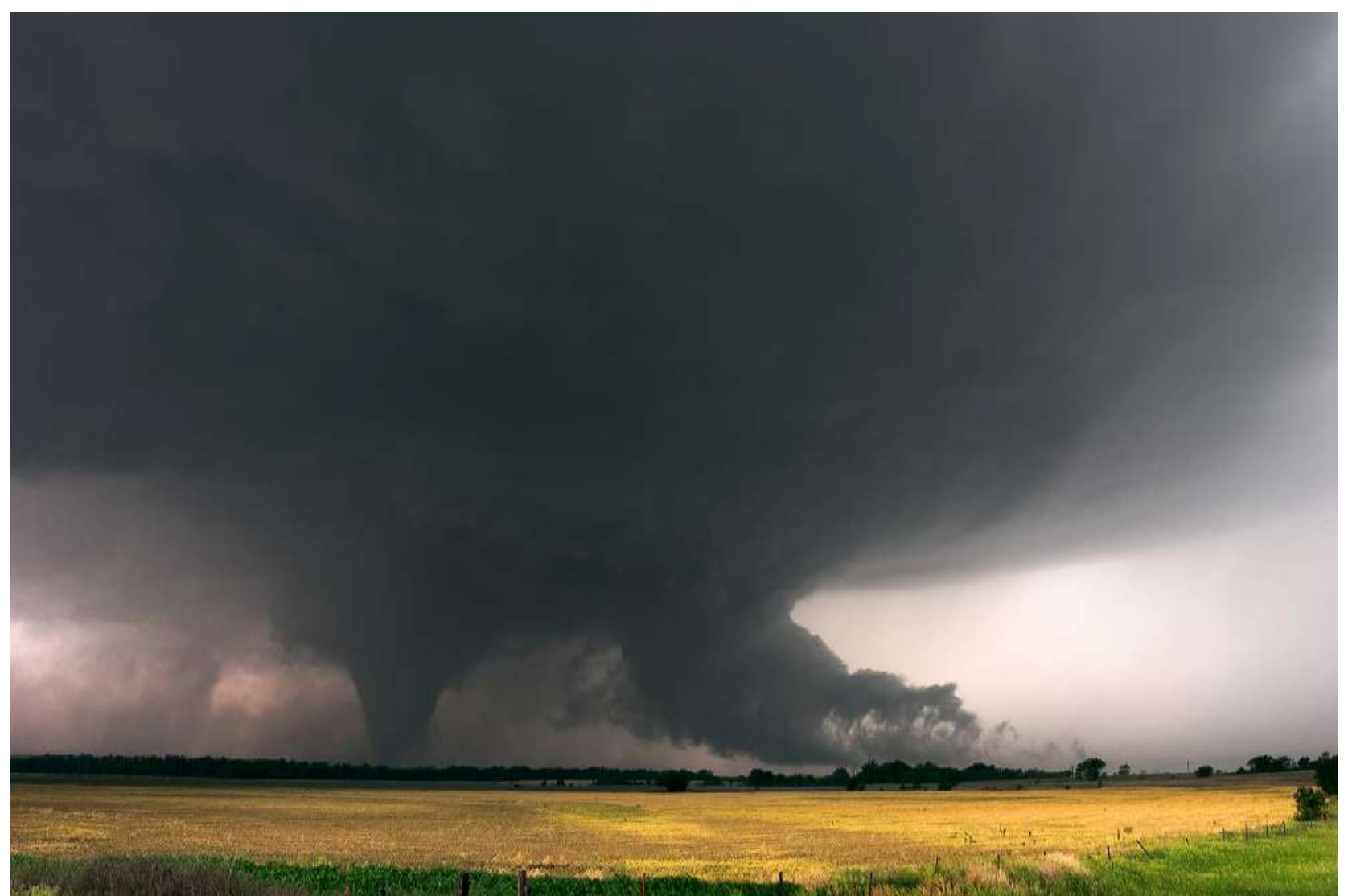

Fig. 3.16. FFD situada a la derecha de la imagen. Tail cloud en el centro-derecha entrando por la base del mesociclón. A la izquierda hay un tornado. A la izquierda del todo estaría situada parte de la RFD y el clear-slot. Foto @ Mike Hollingshead.

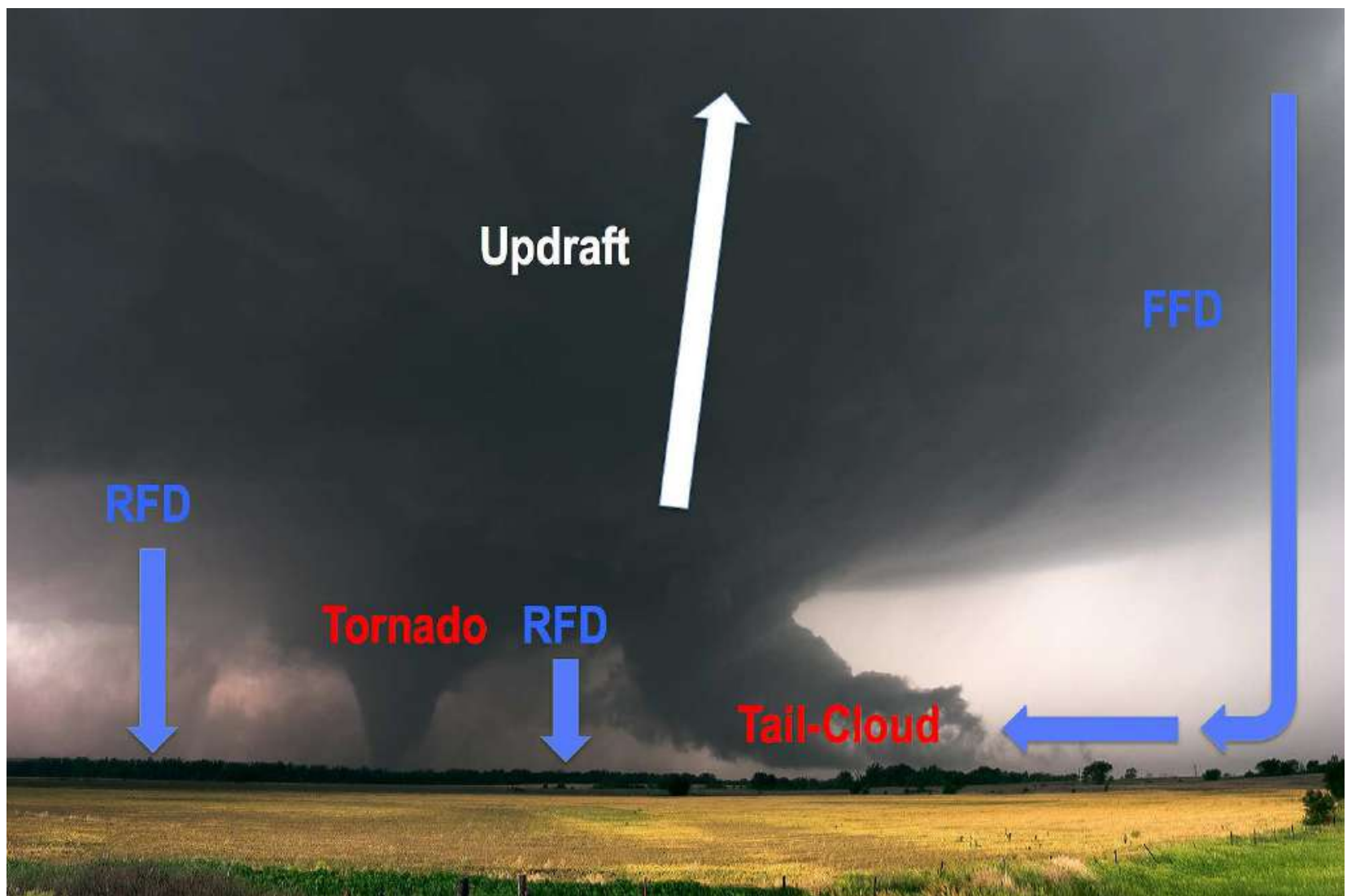

Figura 3.17 Elementos identificados en la figura 3.16. Foto (C) Mike Hollingshead.

Características básicas de las supercélulas en España. Página - 27 - 
En ocasiones puede observarse una banda de nubes a modo de cola de castor (beaver tail), que es una banda de nubes de formas suaves, casi plana, que usualmente se extiende desde el borde oriental de la base libre de lluvia hacia el este, teniendo su base a la misma altura que la base de la corriente ascendente (figuras 3.18 y 3.19).

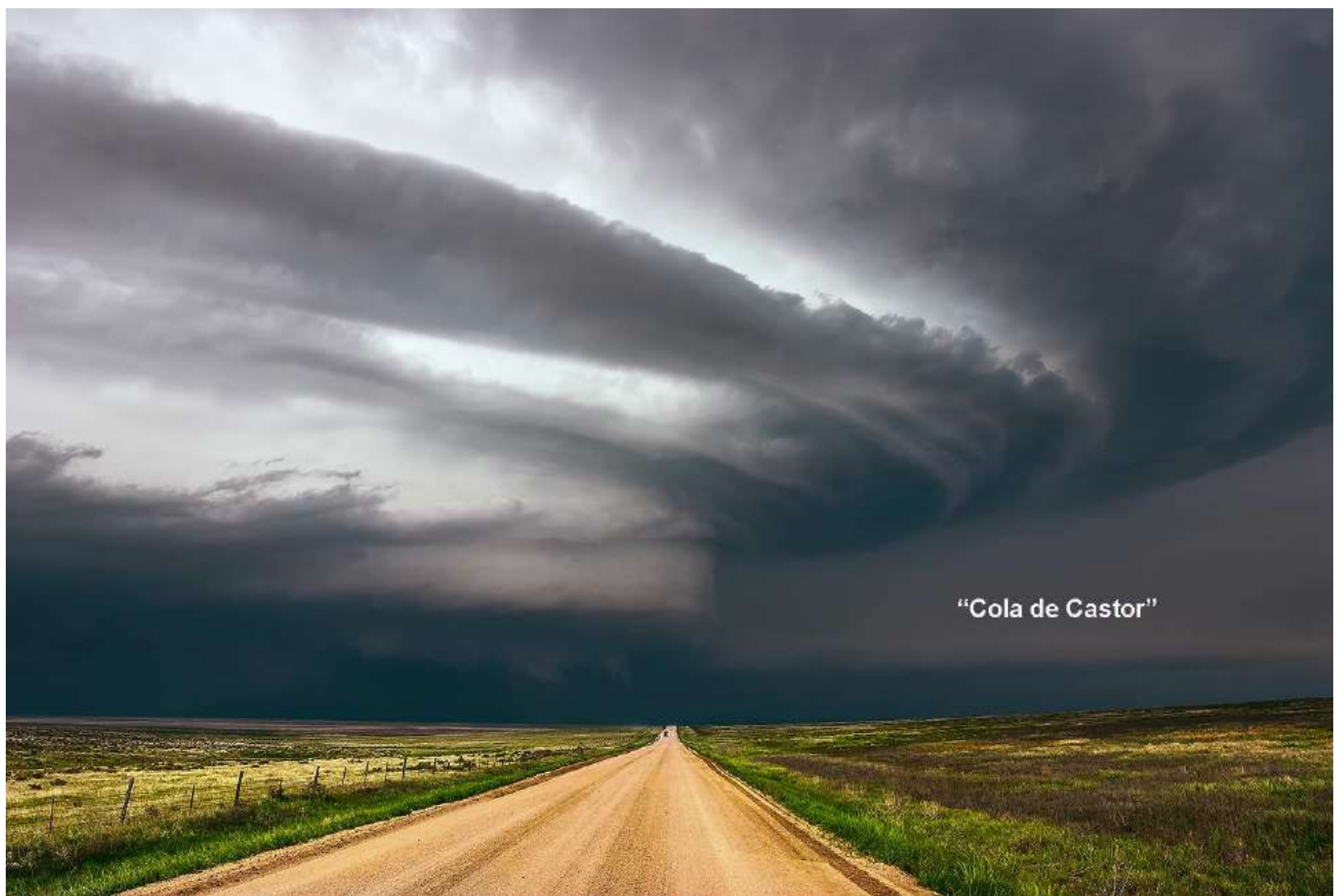

Figura 3.18. Una larga banda de "cola de castor" se aprecia tenuemente al fondo (abajo a la derecha) de la supercélula. Por encima, bandas de nubes en forma de sacacorchos denotan la rotación del mesociclón.

Foto (C) Mike Hollingshead,

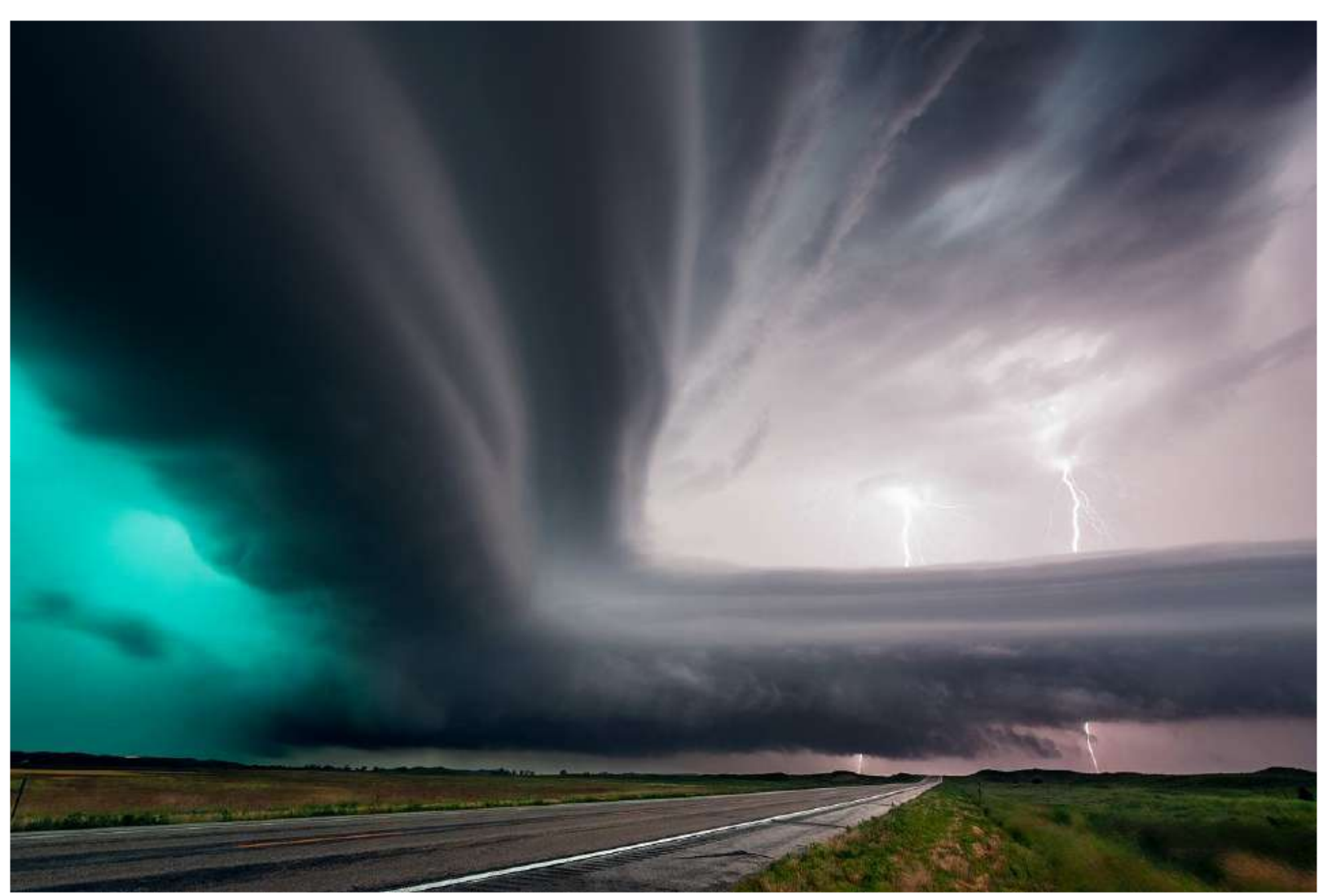

Figura 3.19 Clear slot en color verdoso en RFD a la izquierda, nube estantería en el centro, y "cola de castor" a la derecha, en la fase de colapso de la supercélula. El frente de racha asociado a la RFD está a punto de alcanzar al fotógrafo. Foto (C) Mike Hollingshead

Características básicas de las supercélulas en España. Página - 28 - 
En la fase de colapso de la corriente ascendente supercelular (etapa de decaimiento), la base circular libre de precipitación suele ser erosionada de arriba hacia abajo por la corriente descendente del flanco trasero (RFD), surgiendo el clear slot (figura 3.20), que es la zona de nube más clara, a veces de intenso tono verdoso o incluso cielo despejado, fruto de la evaporación y disipación de la corriente ascendente debido al aire seco que desciende desde arriba.

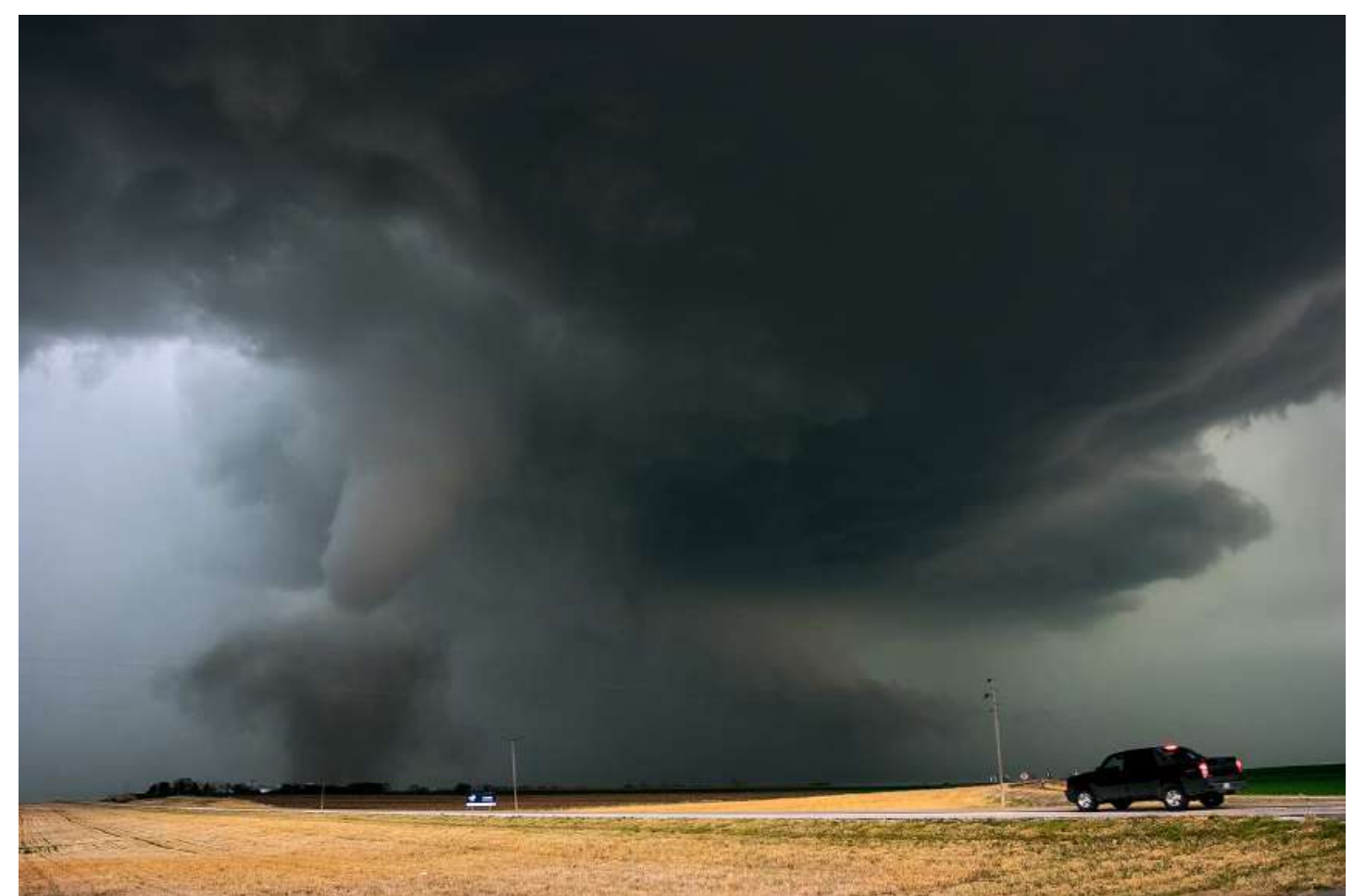

Figura 3.20. Zona libre de nubosidad ("clear slot") a la izquierda del tornado. Esta claridad en la región de la RFD denota el inicio del colapso del mesociclón, y puede ser el precursor de un posible tornado. Foto (c) Mike Hollingshead.

En caso de producirse un tornado mesociclónico (figura 3.21), colgaría directamente de la nube pared o wall cloud en la fase de su colapso hacia superficie.

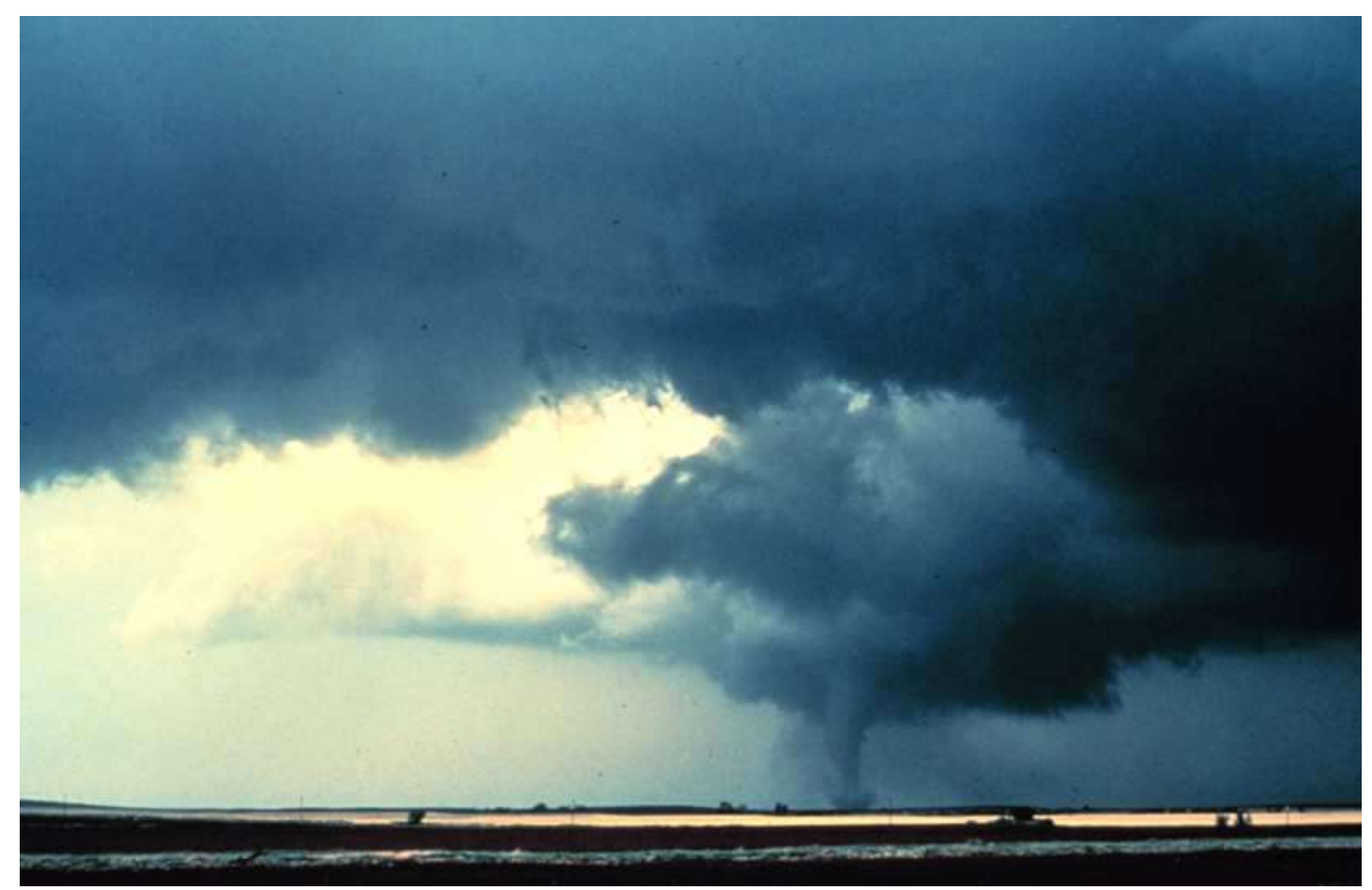

Figura 3.21. Zona libre de nubosidad (clear slot) y formación de un tornado mesociclónico en la fase final de una supercélula. Fuente: http://www.photolib.noaa.gov/nssl/nssl0073.htm National Severe Storms Laboratory (NSSL)

No obstante, en general, un pequeño porcentaje de supercélulas produce tornados mesociclónicos (2025\%). Especialmente en España los tornados no suelen estar asociados a supercélulas, sino que son en su gran mayoría de tipo landspout o waterspout. Véanse ejemplos de cada uno de los dos en las figuras 3.22 y 3.23. 


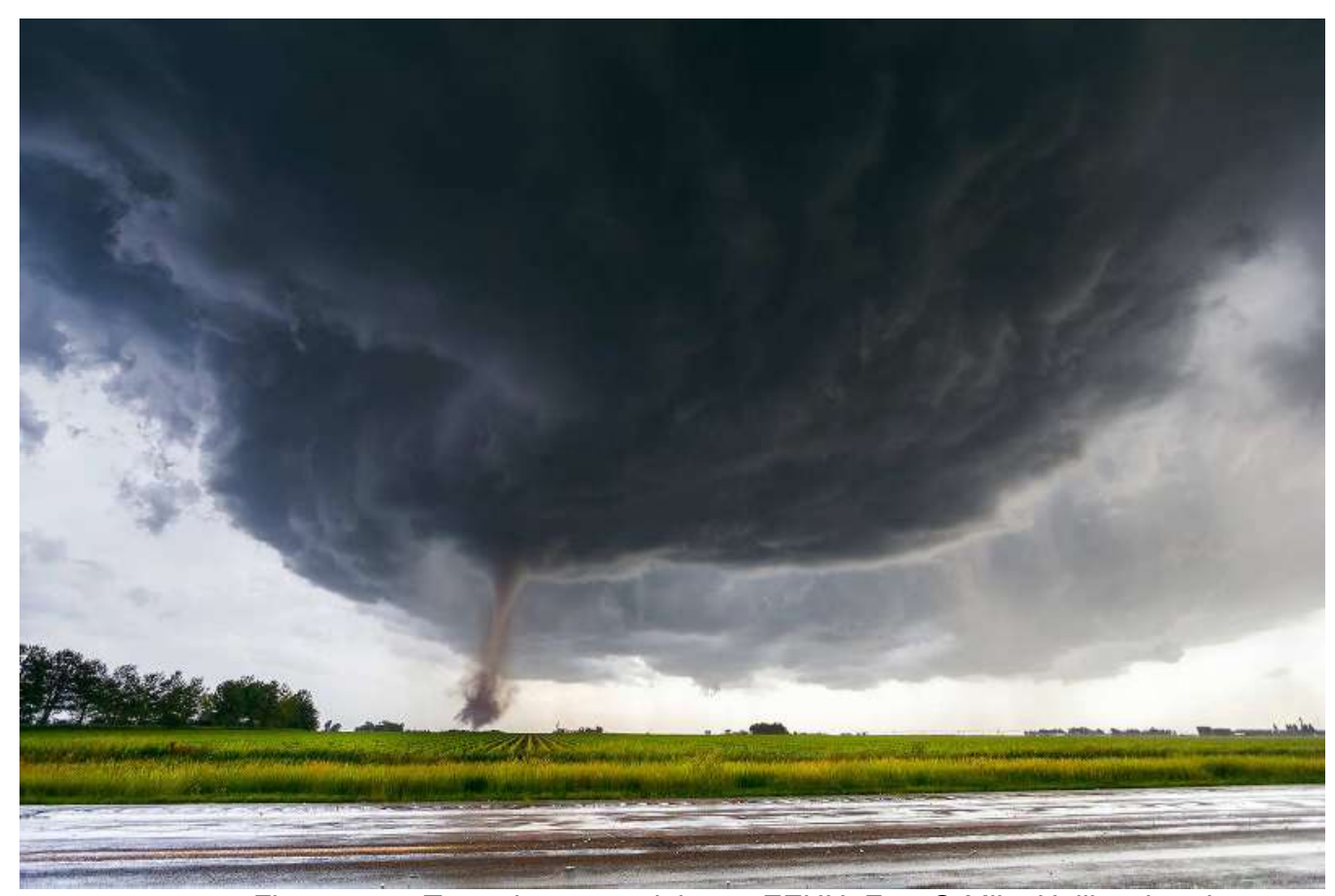

Figura 3.22. Tornado supercelular en EEUU. Foto @ Mike Hollingshead.

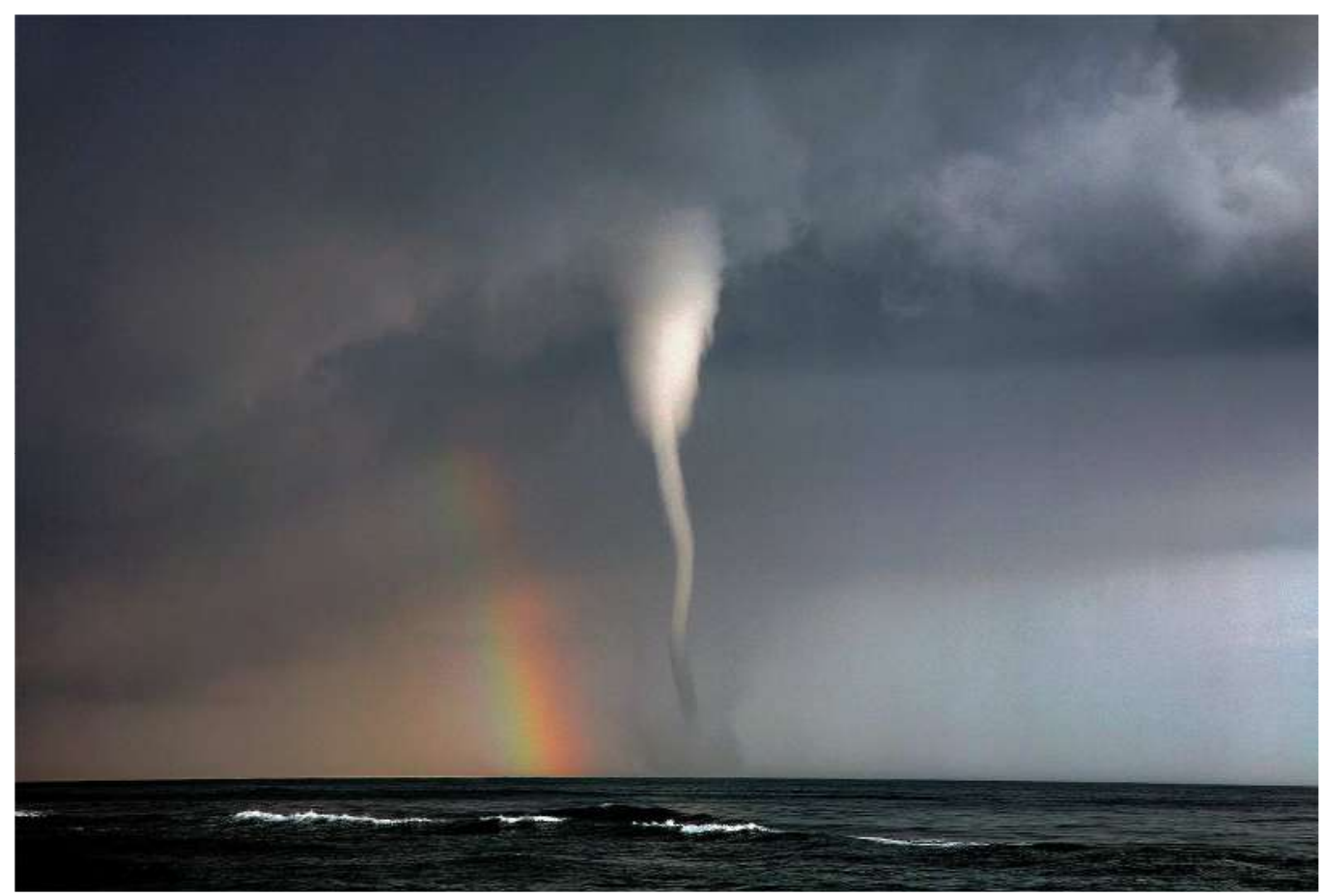

Figura 3.23. Tromba marina o "waterspout" frente a las costas de Barcelona. Foto @ Manuel Massagué Conde.

Existe, por tanto, una clase de tornados no-supercelulares (o mejor dicho no mesociclónicos) que son básicamente tornados que no proceden de una "nube-madre" previa en rotación, como es el caso del mesociclón en una supercélula. Estos tornados son básicamente de dos tipos diferentes: las trombas marinas, mangas o waterspouts que son columnas de agua que se desarrollan bajo $\mathrm{Cu}$ congestus sobre el mar en condiciones de inestabilidad ligera o moderada, apareciendo a veces en grupos; y los landspouts, tornados con una dinámica parecida a las waterspouts pero que se desarrollan tierra adentro. En ambos casos, su génesis viene normalmente originada cuando se forman circulaciones horizontales que son estiradas e inclinadas verticalmente por una tormenta en fase de desarrollo. Al contrario que los mesociclónicos, los tornados tipo landspout o waterspout no suelen pasar de tener una fuerza EF-0 o EF-1 según la escala Fujita mejorada, aunque en casos extremos pueden alcanzar la categoría EF-2. De todos ellos, las trombas marinas (fig. 3.23) son, con diferencia, los tornados más frecuentes en las costas atlánticas y mediterráneas de España. Los gustnados, aunque no suelen ser considerados como tornados, son vórtices generados en cualquier tipo de tormenta (incluidas las supercélulas) por inclinación de la vorticidad baroclina en el frente de racha (gust-front). 
Por último suelen existir en las supercélulas manifestaciones periféricas ligadas a zonas de salida de aire.

Por un lado está el frente de racha (flanking line), figura 3.24, que se produce por convergencia a lo largo de la zona de frontera entre la salida de aire frío de la RFD y el aire cálido que entra en la updraft. Se puede observar como una línea de desarrollo de cumulus congestus desde la updraft de la tormenta hacia fuera, y a veces puede ser identificado en imágenes de satélite. Nuevas células tormentosas podrían formarse a lo largo de este frente de racha, que normalmente se extiende hacia el sur o suroeste de la tormenta en una supercélula ciclónica. Estas nubes se observan desde satélite, en especial en el canal VIS y cuando no están cubiertas o sobrevoladas por nubes medias-altas.

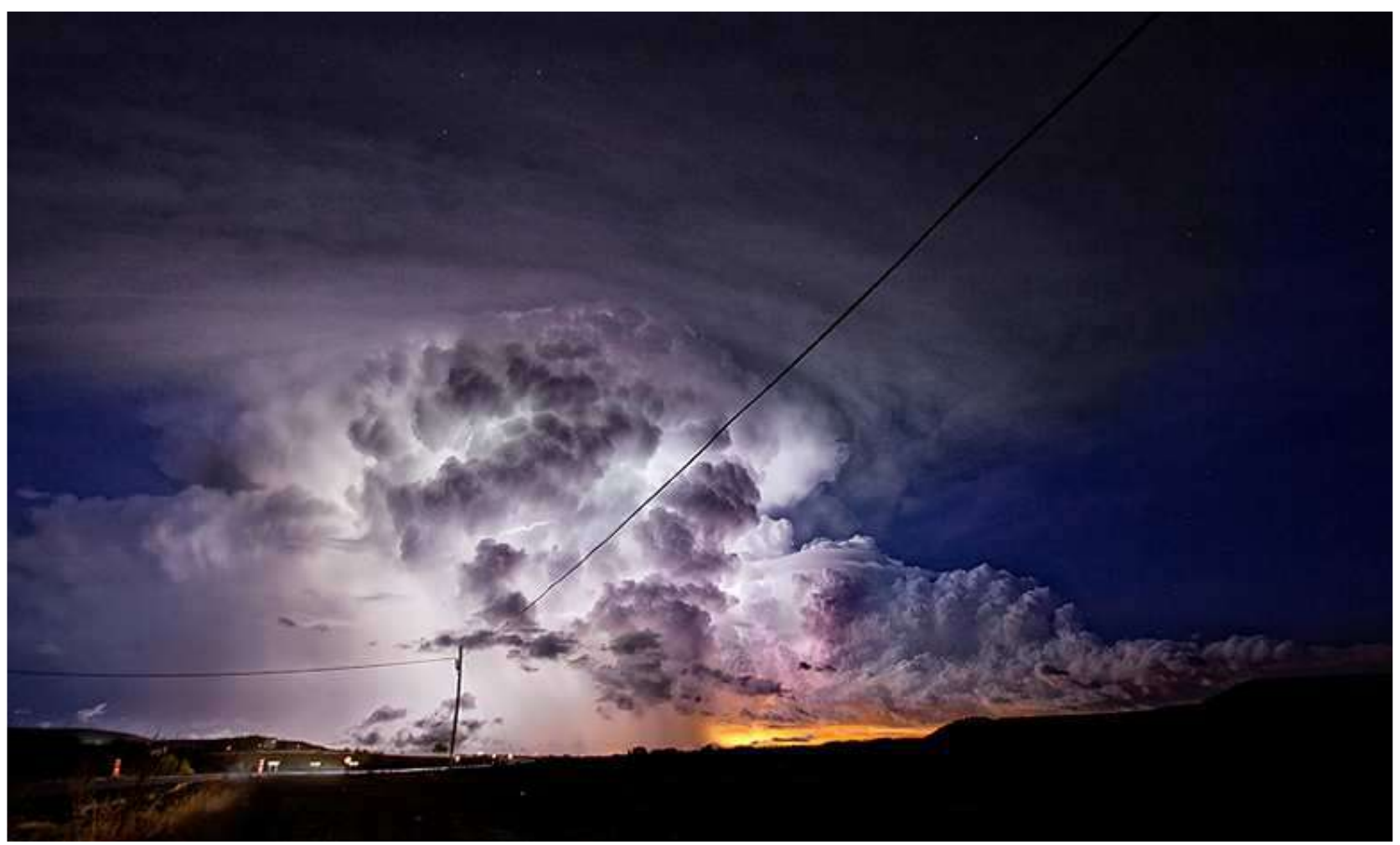

Figura 3.24. "Flanking line" a la derecha de la imagen que enlaza con la "updraft"/mesociclón en niveles bajos. Supercélula tornádica en Palencia-Burgos, 2 de Octubre de 2013. Foto @ José Antonio Gallego Poveda

Otros tipos de nubes a veces presentes son las nubes estante o en forma de cinturón (shelf clouds), figura 3.25, que indican la presencia de una zona de salida de aire hacia fuera de la tormenta, normalmente en su parte delantera. Estas nubes aparecen en niveles medios del mesociclón con diferentes pisos o niveles. Se forman como consecuencia del ascenso forzado del aire estable de las capas bajas dentro del mesociclón, debido al forzamiento dinámico vertical inducido por la rotación en niveles medios. En algunos casos estas nubes estante muestran claramente el giro al que están siendo sometidas, y a veces aparecen junto a la nube en forma de cola de castor (ver figura 3.19).

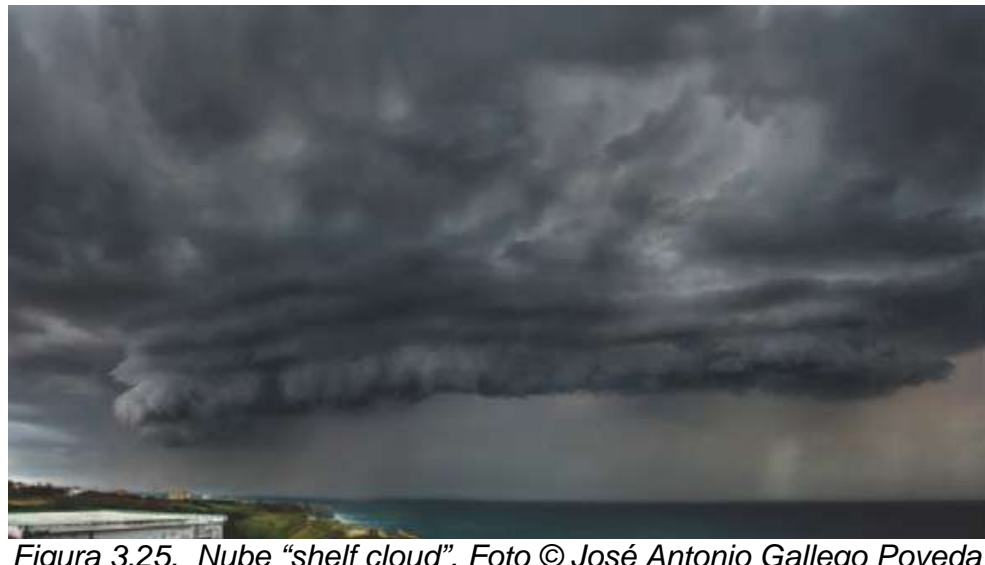

En España la apariencia de las supercélulas (figuras 3.26 y 3.27) es lógicamente análoga a la de Estados Unidos, con una estructura celular idéntica, aunque en muchos casos no se dispone de entornos meteorológicos ni tan inestables ni con tanta cizalladura como allí, lo que da lugar a mesociclones con menor intensidad de giro, y en general de dimensiones inferiores (en vertical y en horizontal), y menor duración. 


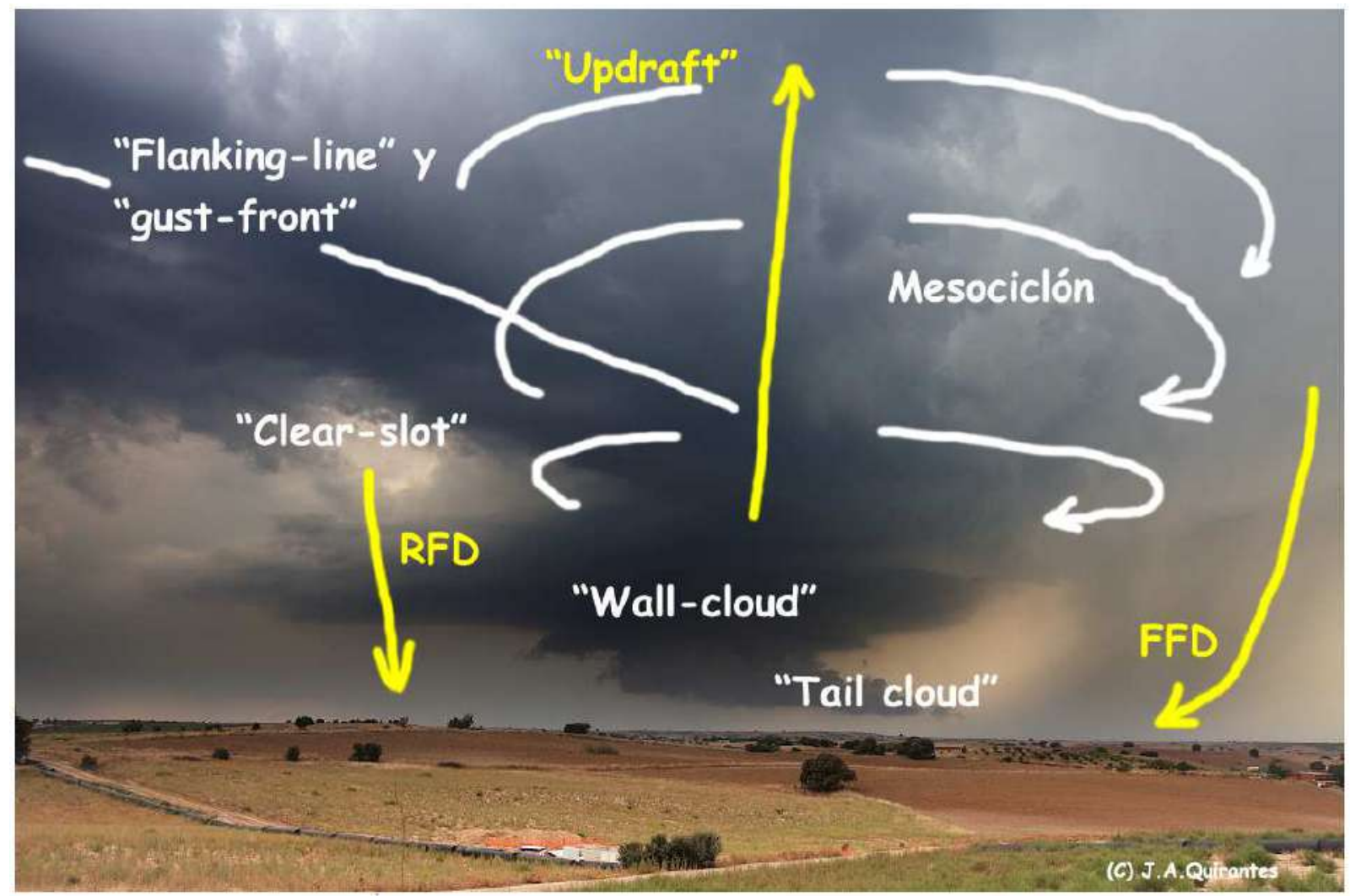

Figura 3.26. Supercélula en Maqueda-Toledo el 1 de Septiembre de 2010, donde el autor, J.A. Quirantes, ha realizado una identificación de las partes más significativas.

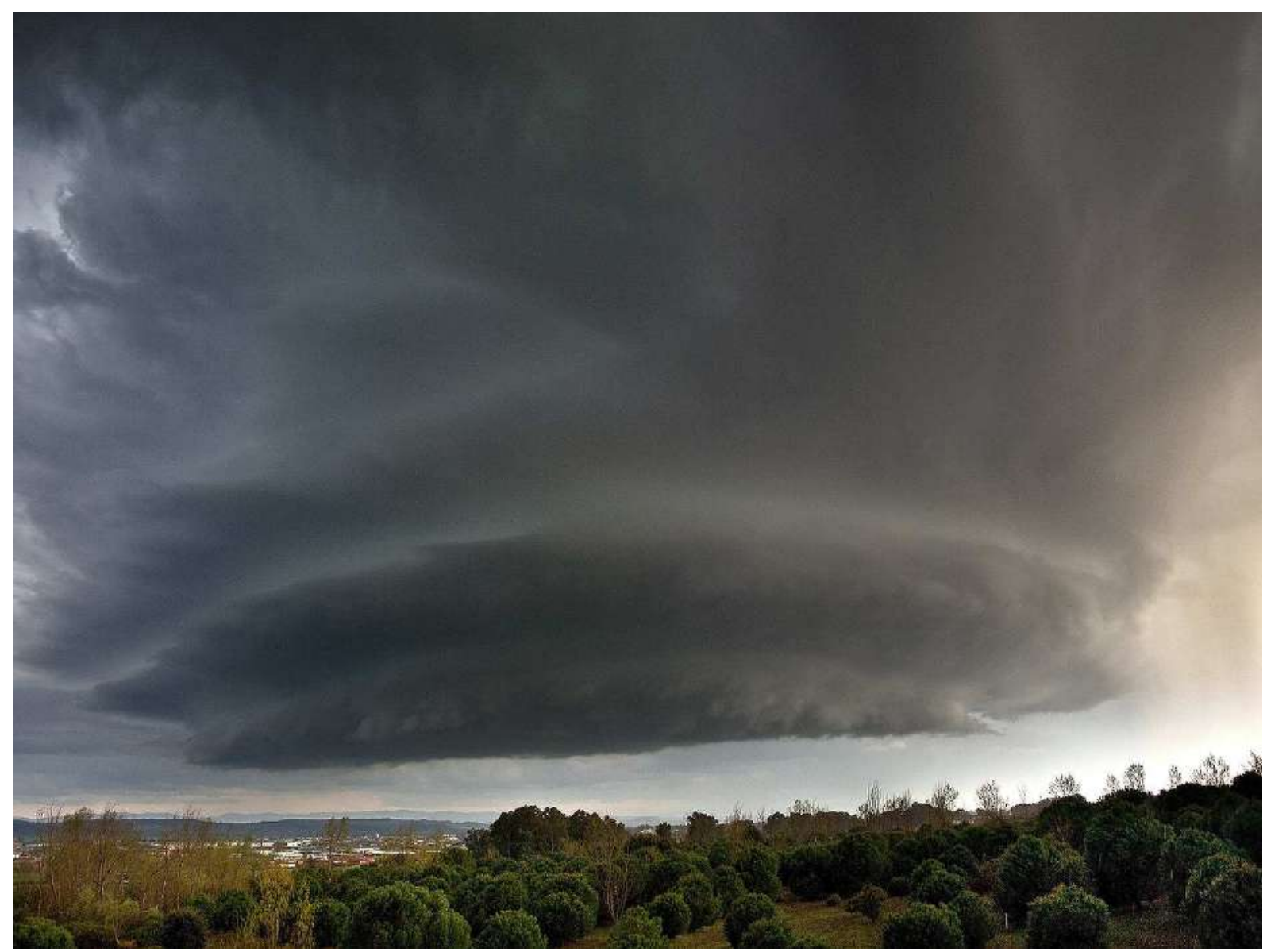

Figura 3.27. Supercélula en Talavera de la Reina, Toledo, el 24 de Marzo de 2011,

Obsérvese la diferencia de esta supercélula, por ejemplo, con la supercélula americana de la figura 3.9. La intensidad del giro del mesociclón es menor, como muestran las bandas de las nubes en forma de sacacorchos. Autor (C) Miguel Cívica Corrales. 


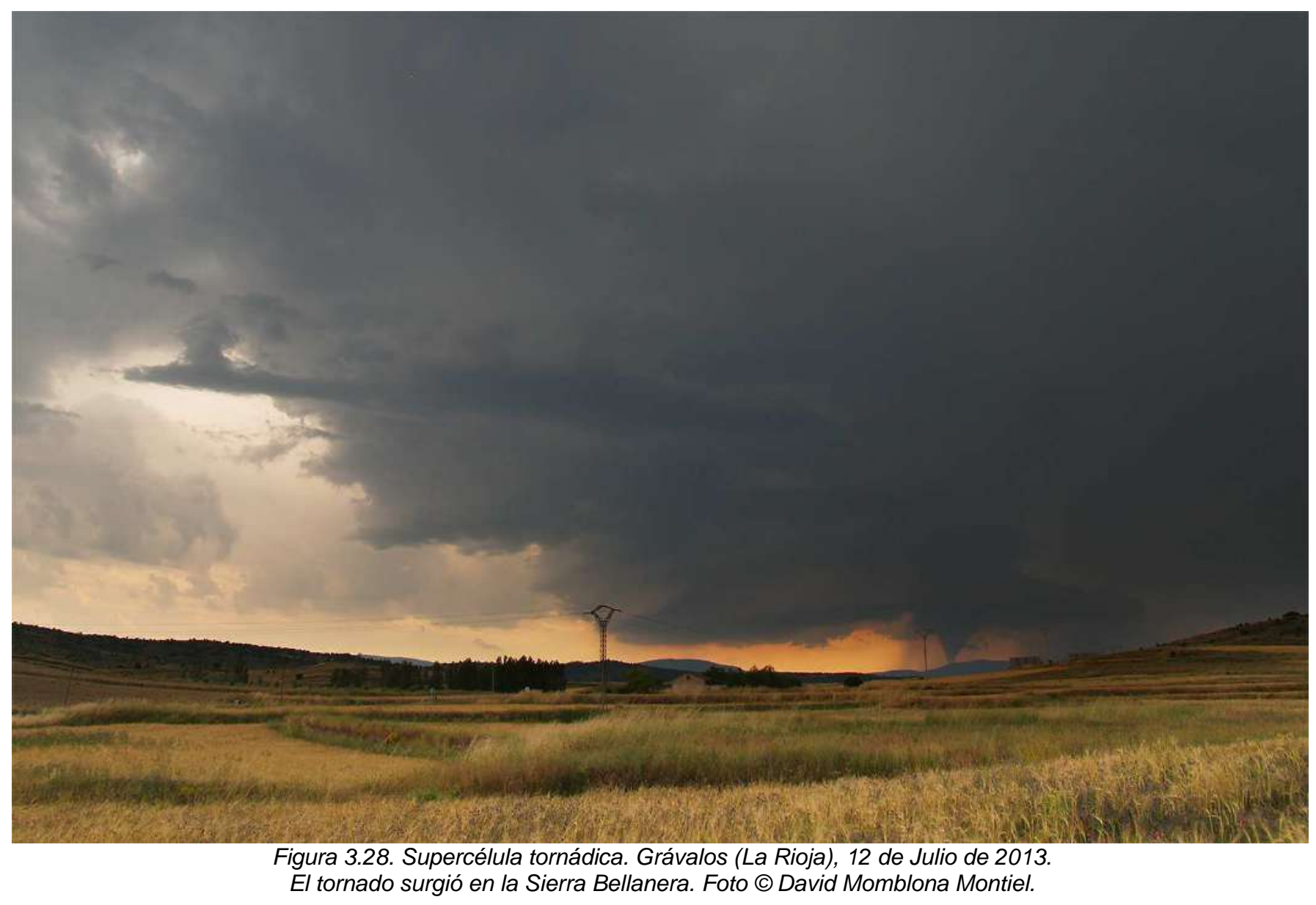

En Estados Unidos, aproximadamente, sólo un 20-25\% de las supercélulas producen tornados. En España este porcentaje puede ser inferior. También son frecuentes en las supercélulas las avenidas relámpago (flashflood) y una enorme frecuencia de rayos intranube, excediendo en ocasiones las 200 descargas/minuto. Además presentan una proporción mucho mayor de intensas descargas nube-tierra positivas con respecto a las descargas negativas, algo opuesto a lo normal en tormentas ordinarias.

En definitiva, una observación visual por parte de personal experimentado y bien entrenado, puede constatar la presencia, muy probable o prácticamente segura, de una supercélula en determinadas ocasiones cuando se detecten los elementos morfológicos anteriormente señalados, compatibles con suficiente intensidad, extensión y duración del giro mesoescalar. No obstante, muchas veces queda cierta duda que sólo puede despejar una buena detección del mesociclón a partir de los patrones inequívocos que muestre el viento radial de radares meteorológicos con tecnología Doppler, algo que en muchos casos es difícil de apreciar en España por diversos motivos que más adelante se citarán.

Como se recomienda en el Weather Spotter's Field Guide de la NOAA, los cazatormentas deben determinar la posición y movimiento de la tormenta, lo cual a veces no es fácil de conseguir visualmente, por lo que pueden usar datos de un sistema de radares que les sirva de apoyo. Una vez conseguido lo anterior, el posicionamiento óptimo debe ser tal que se pueda identificar la zona de la corriente vertical de la supercélula. Para una tormenta que se mueve hacia el nordeste, la mejor ubicación para su visualización es al sureste de la misma. En la figura 3.3 se muestra esa zona, que correspondería a la región coloreada en verde. Es precisamente ese emplazamiento desde el que se podría detectar visualmente la zona libre de precipitación por encima de la que se sitúa la corriente ascendente, y donde se pueden formar la nube pared e hipotéticamente algún tornado. En cualquier otra posición, la lluvia o el granizo pueden tapar la visión de los elementos nubosos clave en la zona de ascensos. También hay que tener presente que no todas las tormentas se desplazan de SW a NE. Aunque las tormentas en general se mueven en la misma dirección que el flujo rector en niveles medios de la troposfera, las supercélulas se desvían usualmente a la derecha del viento en capas medias.

Por último el uso de técnicas de fotografía y video (especialmente los que usan la técnica time lapse) pueden servir de ayuda a posteriori para una mejor identificación y conocimiento de las estructuras. No obstante, como veremos, su identificación se debe combinar a ser posible con la observación radar y con el diagnóstico convectivo de la situación. 


\section{3.- Observación general radar de una supercélula}

Las supercélulas pueden ser identificadas a partir de imágenes de un radar Doppler, ya que muestran características muy peculiares sólo presentes en este tipo de tormentas. A veces, con un buen sistema de radares Doppler se pueden apreciar elementos que a simple vista pueden quedar ocultos o pasar inadvertidos. Por ello el radar es muy útil para la caracterización de las supercélulas, especialmente como complemento de la observación visual, de manera que en determinados casos, patrones que aparecen en el radar nos puedan hacer concluir, ya categóricamente, que nos encontramos ante una supercélula. En la imagen 3.29 aparece una supercélula vista desde arriba, aunando en la misma figura los bordes nubosos observados por satélite y la señal radar, y mostrando los patrones típicos.

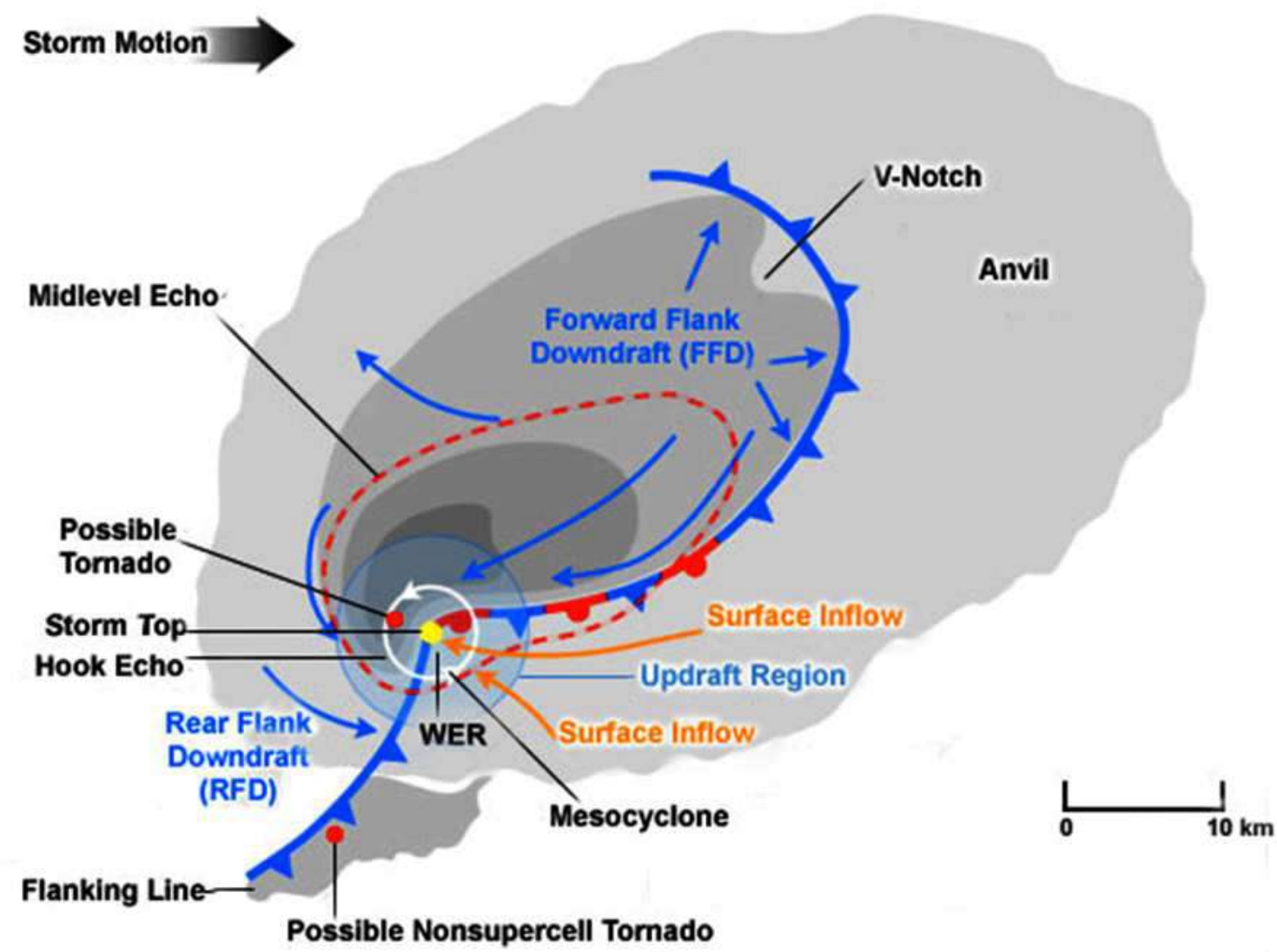

๑The COMET Program

Figura 3.29. Modelo conceptual clásico de supercélula vista por satélite y las estructuras vistas por el radar. Fuente: National Severe Storms Laboratory (NWS)

Una supercélula clásica presenta una estructura en forma de gancho en la imagen de reflectividad radar en niveles bajos (figura 3.30.dcha), apreciable en la zona trasera derecha de la tormenta. Esta forma de eco aparece debido a la interacción entre los descensos y la zona ocupada por la corriente ascendente. En esta región, los vientos denotan claramente un giro, y la precipitación muestra una forma espiral. El gancho rodea una muesca sin señal, por ausencia de precipitación en la zona, causada por el flujo de aire cálido y húmedo alimentador de la tormenta. Este hueco o muesca se llama región de eco débil (WER: Weak Echo Region).

Otro de los patrones típicos es el asociado al giro característico y persistente (al menos durante unos 10 a 20 minutos) del mesociclón (que puede ser ciclónico -en la mayoría de las ocasiones- o anticiclónico). Este giro es observable en la imagen de viento radial Doppler del radar (figura 3.30.izda), en el que cada punto da una idea de la velocidad radial de acercamiento o alejamiento al propio radar. De este modo la señal del mesociclón vendrá dada por un par de señales intensas, adyacentes y de signo opuesto, una de tonos azules denotando acercamiento al radar, y otra de tonos rojos representando alejamiento del radar, que conjuntamente indicarán el giro existente. 

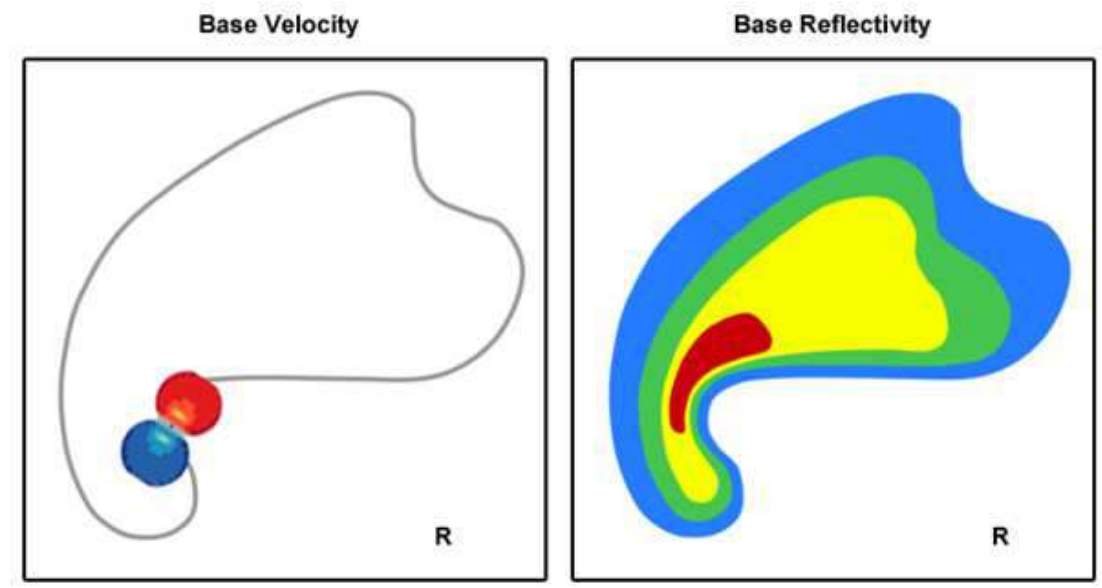

OThe COMET Program

Figura 3.30. Patrones típicos de las supercélulas. Izquierda: giro asociado al mesociclón en el viento radial Doppler.

Derecha: gancho y región de eco débil en el producto PPI de reflectividad radar. Fuente: The Comet Program

En la figura 3.31 podemos ver ejemplos de la imagen de reflectividad en la exploración radar más baja de tres tipos de supercélulas en Estados Unidos (supercélula clásica, supercélula de baja precipitación -LP- y supercélula de elevada precipitación -HP-).
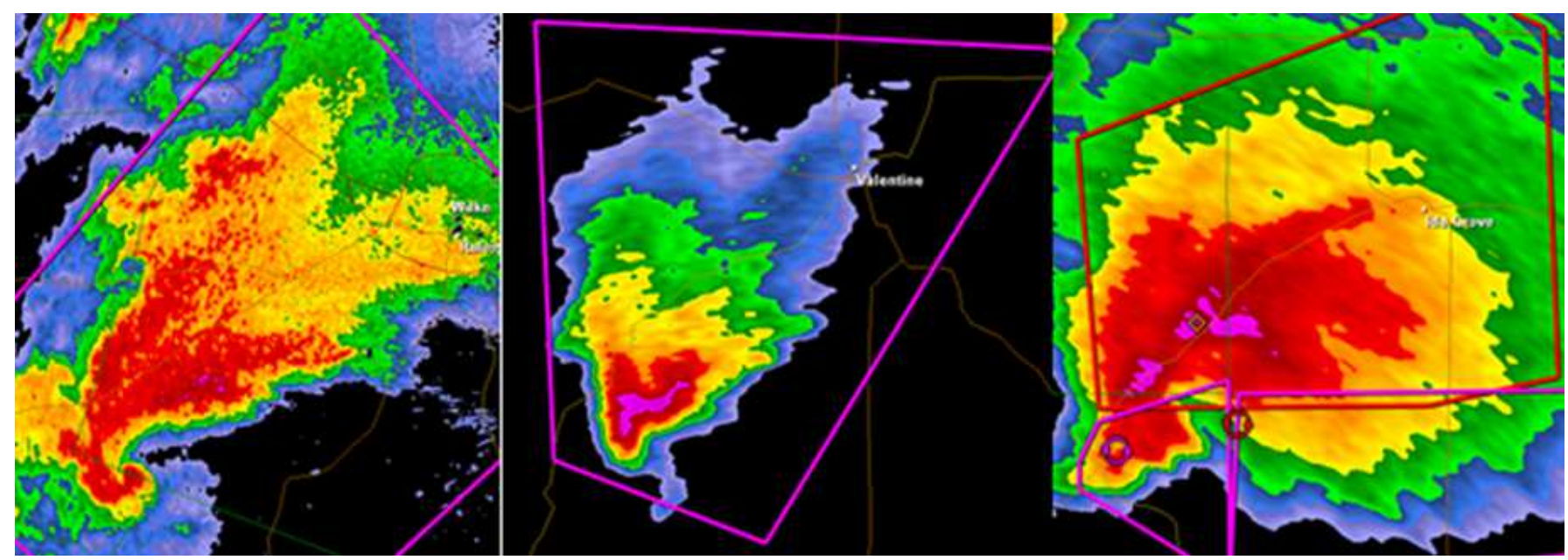

Figura 3.31. De izda a dcha: supercélula clásica (North Carolina), supercélula LP (Nebraska), y supercélula HP (lowa).

Fuente: http://www.ustornadoes.com/wp-content/uploads/2013/02/types-of-supercells 1.png

A continuación veremos algunos de los patrones típicos reconocibles teóricamente en una supercélula madura visualizada por un radar con buena exploración.

\section{- Patrones típicos de reflectividad en la horizontal en capas bajas (fase madura de una supercélula)}

Las siguientes estructuras pueden ser visualizadas en un producto de reflectividad radar en niveles bajos (CAPPl: corte horizontal o $P P I)$, figura 3.32.izda:

- Área de fuerte gradiente de reflectividad, distinguiéndose valores muy bajos en la zona de alimentación de la tormenta, inflow, y valores muchos más altos en la zona interior de la tormenta

- Estructura de gancho en la horizontal asociada a la precipitación descendente (flanco delantero y trasero, aunque el gancho propiamente dicho se correspondería con el flanco trasero). Esta señal indica que el mesociclón se ha formado en niveles medios. En vez del típico gancho a veces aparecen otras estructuras similares, en forma de coma, lágrima, etc. Existe alta correlación entre la posición del gancho y la hipotética zona de aparición de un tornado (si lo hubiese) en la fase de colapso supercelular. No obstante, no siempre se puede identificar el gancho en una supercélula, pero si así fuera, cuanto más intensa sea la corriente descendente trasera, más marcado aparecería el gancho. 
Las características más significativas y diferenciales (figura 3.32.dcha) son las que se enumeran a continuación.

- En una representación plana de reflectividad (CAPPI) en capas medias-altas, habría una zona de máxima reflectividad sobre el área de no eco en CAPPIs más bajos y justamente encima de la zona de fuerte gradiente en capas bajas.

- Las corrientes ascendentes poseen gran intensidad y son capaces de sostener gran cantidad de precipitación. La zona abalconada se eleva y la región de eco débil en niveles altos aparece rodeada de una zona de ecos en forma de gancho, denominada REDA, Región de Eco débil Acotada (BWER: Bounded Weak Echo Region).

- Los valores máximos de reflectividad suelen ser muy altos (normalmente iguales o superiores a 60 dBZ) y estar situados en niveles medios-altos. A veces esta zona se sitúa superpuesta en la vertical sobre la RED, Región de Eco Débil (WER: Weak Echo Region), en niveles bajos y sobre una BWER en niveles medios/altos.

- La precipitación presenta una estructura abalconada, y la corriente ascendente vertical una forma abovedada, con un gancho en la vertical.

- Los valores de echotop (altitud de una zona con un valor de reflectividad superior a un determiando umbral) suelen ser en general altos (más de $12 \mathrm{~km}$ ), aunque no siempre como ocurre con las mini supercélulas. Además el máximo echotop estaría desplazado respecto a los máximos de reflectividad en niveles bajos.

- El VIL (Vertical Integrated Liquid, o contenido de agua líquida de la columna) posee valores altos o muy altos, lo que infiere la presencia de grandes piedras de granizo en el seno de las corrientes ascendentes y descendentes.

- V-notch, o patrón característico que es una muesca en forma de "V" que se forma corriente abajo del viento en niveles medios-altos. Es un signo de flujo divergente alrededor de la corriente ascendente. Su presencia marcada suele indicar que la corriente ascendente es muy intensa.

- También a veces puede ser identificado el clear slot, que es una zona sin ecos relacionada con la corriente descendente del flanco trasero de la supercélula en la fase de colapso, que se forma en el momento de oclusión de la corriente ascendente, y que a veces es el elemento precursor de la aparición de un tornado. En el momento de una hipotética tornadogénesis, el echotop suele caer bruscamente entre 1 y $3 \mathrm{~km}$.

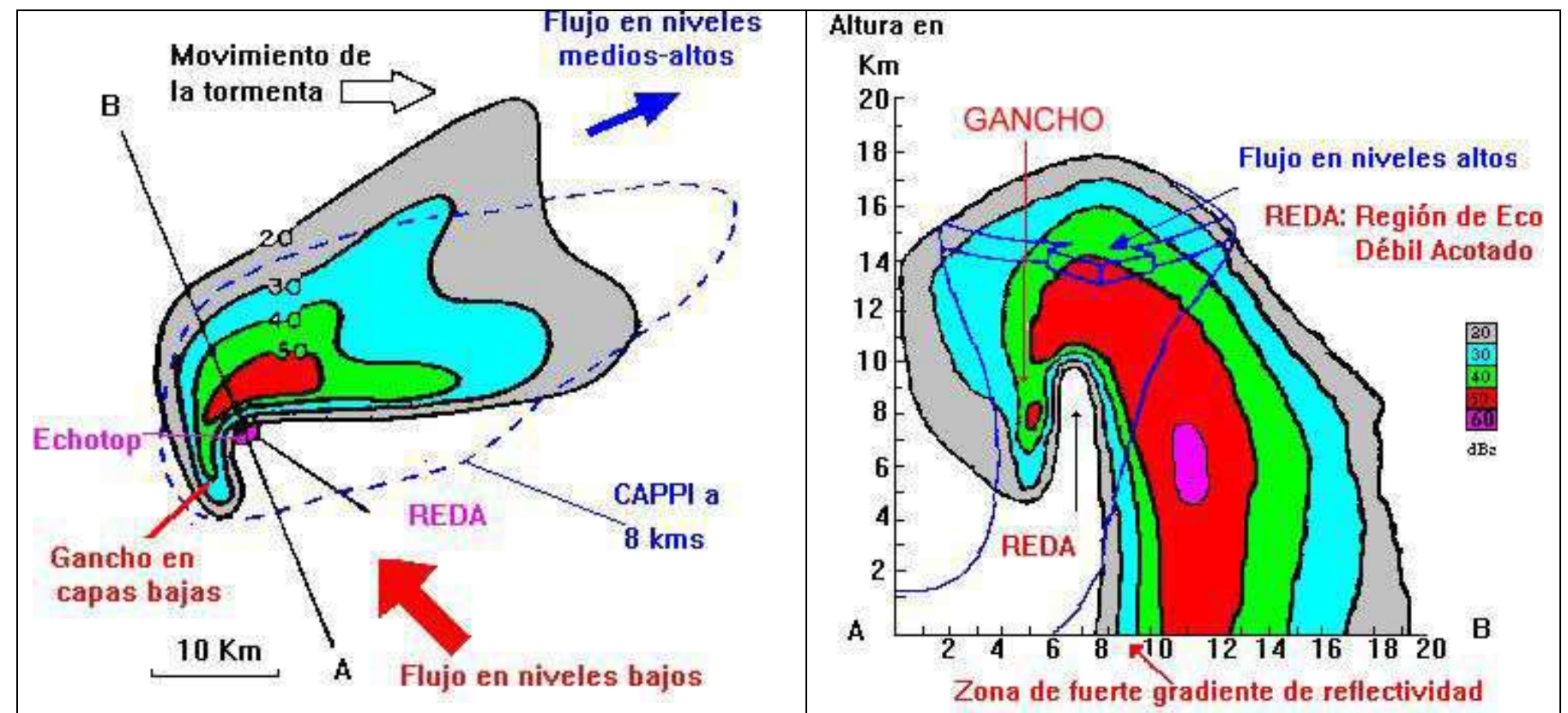

Figura 3.32. Estructura típica de una supercélula en fase de madurez. Izda: vista horizontal en capas bajas. Dcha: corte vertical. Fuente: Módulos TEMPO. Martín y Riosalido, 1999. AEMET 


\section{Patrón típico de viento radial Doppler en supercélulas}

En la observación radar, una condición suficiente para garantizar que estamos ante una supercélula es identificar la rotación del mesociclón (o mesoanticiclón) a partir del producto viento radial Doppler.

El mesociclón suele mostrar las siguientes características:

- menos de $10 \mathrm{~km}$ de diámetro (generalmente entre 3 y $8 \mathrm{~km}$ de extensión horizontal)

- una dimensión vertical (espesor) de al menos $3 \mathrm{~km}$, aproximadamente,

- una duración mínima superior al menos a 10 ó 20 minutos

Generalmente las escalas espacial y temporal del patrón identificado están fuertemente relacionadas con la intensidad de la corriente ascendente. En este caso, cuanto más grande y persistente sea el mesociclón, en general más intensa será la supercélula. También parece existir una relación directa entre la intensidad de la supercélula y la magnitud del giro.

Para la detección radar del mesociclón debemos utilizar el producto de velocidad radial de un radar Doppler, que nos indica en cada punto de exploración (a su altitud correspondiente), la velocidad de acercamiento o alejamiento en la dirección radial al radar de las partículas en movimiento (gotitas de agua líquida o sólida). Por tanto se está aprovechando la capacidad Doppler del radar, que identifica cambios de longitud de onda de la señal devuelta por los ecos en movimiento (gotas, gotitas, partículas de hielo, etc.) respecto a la longitud de onda de la señal emitida. En cambio las partículas que se mueven perpendicularmente al haz del radar tienen velocidad radial cero (ni se alejan ni se acercan en la dirección radial hacia el emplazamiento del radar).

Para identificar el mesociclón deberemos comprobar y localizar la existencia persistente (al menos en dos imágenes consecutivas) de dos máximos relativos de viento radial con sentidos opuestos, muy cercanos y que cumplan la propiedad de que el segmento que los une sea más o menos perpendicular a la radial al punto donde está localizado el radar (figura 3.33). Esta característica es la prueba inequívoca de que la tormenta es supercelular.

Normalmente colores cálidos (tonos amarillos o rojizos) se usan para representar movimientos de alejamiento del radar, mientras que colores fríos (tonos verdes o azules) se usan para velocidades radiales de acercamiento al radar (figura 3.34). Así podemos asumir que si detectamos a ambos lados de un radio hacia el radar, una zona reducida con vientos alejándose y justo al lado vientos acercándose al radar, entonces estamos ante una probable rotación mesoescalar. Por ello para detectar el mesociclón debemos ver una zona pequeña de colores cálidos junto a otra de colores fríos, con una línea de separación entre ellos en la dirección radial hacia el radar. Esta última condición es muy importante pues si la línea entre ambas señales de movimientos de sentido opuesto no fuese paralela al radar, no hablaríamos de rotación sino probablemente de convergencia o divergencia. Cuanto más intensas sean ambas señales, más fuerte será la rotación en esa pequeña área y por tanto más intenso será el mesociclón, que aproximadamente debe tener una extensión vertical de al menos unos $3 \mathrm{~km}$.
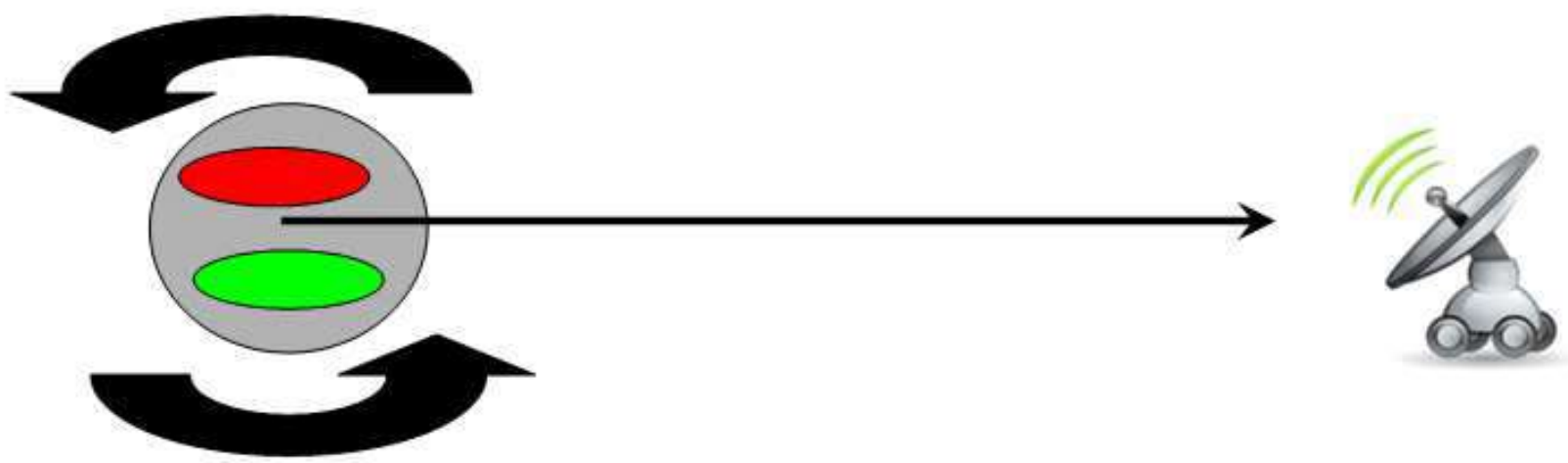

Figura 3.33. Identificación del mesociclón supercelular a partir de un patrón típico de señales que denotan un giro intenso mesoescalar (ciclónico en este caso) . 
Hay que tener en cuenta, que aunque la gran mayoría de las supercélulas en el Hemisferio Norte son de tipo mesociclónico (con giro contrario al avance de las agujas del reloj), también pueden ser mesoanticiclónicas (con giro según el avance de las agujas del reloj).

Como ejemplo clarificador se muestra la figura 3.34. En ella, arriba, aparece una imagen de detección de la supercélula en un $P P I$ de reflectividad en la que se aprecia el gancho, la zona donde presumiblemente se sitúa el mesociclón, así como la muesca propia del flujo alimentador en capas bajas. En la imagen de abajo se muestra otra imagen de detección del patrón típico inequívoco asociado al mesociclón con identificación de dos zonas próximas de alejamiento-acercamiento al radar que denota la existencia del giro mesoescalar en el viento radial Doppler.

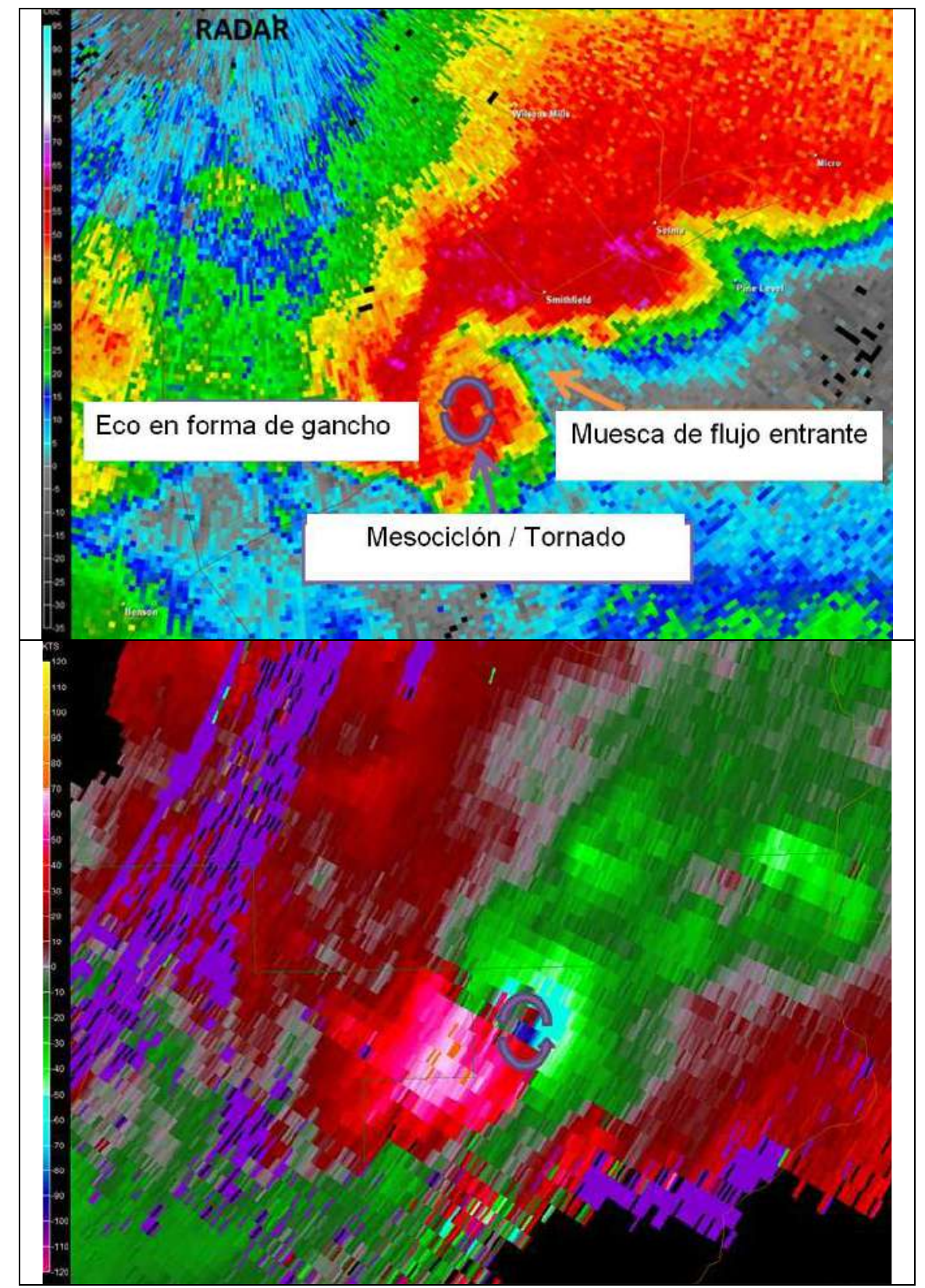

Figura 3.34. Arriba: PPI de reflectividad donde se aprecia un gancho. Abajo: Identificación de un giro mesoescalar típico del mesociclón supercelular. Fuente: National Weather Service.

Es importante volver a insistir en que el mesociclón debe tener una extensión vertical de al menos aproximadamente unos $3 \mathrm{~km}$ y tener cierta persistencia (como mínimo de 10 a 20 minutos). La detección del mesociclón en radar es síntoma inequívoco de que la estructura es supercelular.

Si hubiera un tornado mesociclónico, desencadenado durante la fase de colapso de la supercélula, teóricamente se identificarían dos nuevos máximos de viento más intensos, adyacentes y opuestos, dentro del mesociclón, aunque no concéntricos con él. Hay que tener en cuenta que el diámetro de los tornados suele ser de unas decenas o centenares de metros, normalmente sin llegar al kilómetro, por lo que la detección será muy complicada si la resolución del radar no es suficientemente alta. 


\section{4.- Observación de supercélulas mediante radar en España}

Aunque como hemos visto la observación del mesociclón persistente en radar es una prueba concluyente para afirmar que una tormenta es supercelular, este patrón no es fácil de identificar en un buen número de casos.

De cualquier manera la información radar no debe usarse de manera aislada, sino en conjunción con otras fuentes como las condiciones meteorológicas del entorno de la tormenta, y por supuesto, y si fuera posible, la visualización directa de la tormenta, tratando de identificar las estructuras nubosas principales y características, algo que desde luego tampoco es siempre fácil de conseguir, incluso aunque se tenga experiencia en la observación de tormentas severas.

\subsection{1.- Problemas generales en la observación radar de supercélulas}

Antes de ver las peculiaridades de la red de radares de AEMET, trataremos de poner de manifiesto algunas dificultades inherentes a la exploración radar de posibles supercélulas.

Una de las primeras cuestiones que hay que tener presente es la evolución temporal de los patrones característicos identificables en el radar. Así, cuando comparamos signos potenciales de severidad, debemos tener presente la calidad de la información radar en la zona de exploración, valorando bloqueos parciales y totales.

También existen problemas debidos a los algoritmos utilizados en la exploración radar, que hacen que aparezca ruido, especialmente en la señal de viento radial, muchas veces falsos, especialmente valores que se pueden considerar espurios ya que no tienen una explicación física consistente con una necesaria consistencia espacio-temporal de las imágenes. Especial cuidado debe prestarse a las magnitudes exactas de valores extremos (elevados), los cuales pueden estar por el contrario infravalorados (cuando el viento radial supera la máxima velocidad no ambigua, $+/-48 \mathrm{~m} / \mathrm{s}$, se asignan colores opuestos en la escala de viento).

Un hecho clave es la degradación de la resolución del haz con la distancia al radar. Cuando se observa con el radar una tormenta muy alejada de aquél, el haz de exploración será muy ancho en la zona de la tormenta y la señal puede parecer bastante más débil de lo que es en realidad, quedando claramente suavizado por ejemplo un mesociclón. Esto puede ser especialmente grave en mini-supercélulas. Por tanto, las exploraciones a cortas distancias son generalmente mucho mejores en cuanto a fiabilidad.

También hay problemas graves a grandes distancias del radar, cuando parte de la tormenta puede quedar por debajo de la zona de exploración, o incluso sin poderse apenas explorar, como puede ocurrir con algunas minisupercélulas muy alejadas del emplazamiento del radar. A esto se suma en la parte explorada, la degradación de la resolución del haz con la distancia.

Además plantea dificultades la duración del ciclo de exploración radar. Cada 10 minutos el radar realiza una exploración volumétrica completa y genera un nuevo volumen polar de datos. Tenemos que tener en cuenta que hay mesociclones que pueden durar tan sólo un intervalo de 20 minutos aproximadamente, y por tanto podrían ser sólo muestreados en una sola imagen.

\subsection{2.- Problemas generales en la observación radar de supercélulas en España}

Aparte de todas las dificultades generales vistas anteriormente de cara a la identificación de supercélulas por medio del radar, en España se agudizan los problemas debido a varios motivos que se describen seguidamente.

En primer lugar hay un problema importante en la exploración radar y es el asociado a la orografía compleja de España, que bloque con frecuencia el haz del radar, por lo que aparecerán no pocas zonas ciegas, sin exploración, en el ciclo de vida de alguna tormenta.

Por otra parte, las supercélulas en España presentan usualmente duraciones muy inferiores a las de los Estados Unidos, con movimientos verticales en general menos intensos y mesociclones más reducidos en extensión vertical y horizontal, con giros menos potentes. Además, algunas de las supercélulas en España son de tipo minisupercélula, cuya exploración con radar, como ya se ha visto, se hace más difícil.

También hay problemas derivados de las características de la exploración de la red de radares de AEMET, los cuales deben ser considerados como limitaciones de cara a la detección de mesociclones. En la estrategia de exploración actual de la red de radares de AEMET se dispone de datos de viento radial, en rango corto, en las

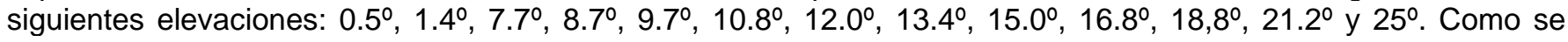
puede observar queda un hueco grande entre $1.4^{\circ}$ y $7.7^{\circ}$, circunstancia importante como veremos a continuación. 
El producto viento radial Doppler, que es el que nos puede confirmar categóricamente la existencia de un mesociclón, sólo se genera para exploraciones de rango corto, con un alcance operativo de $120 \mathrm{~km}$ alrededor de cada uno de los emplazamientos de los 15 radares disponibles (13 en la Península, uno en Baleares y otro en Canarias). Ello hace que en primera instancia haya extensas zonas no cubiertas por dicho producto (figura 3.35). Esta limitación viene dada por dos factores: 1- Mantener un valor de máxima velocidad no ambigua suficientemente alto (+/-48 m/s), una alternativa sería ampliar el alcance a costa de reducir la máxima velocidad no ambigua. Y 2- Los radares de AEMET son de banda C. En EE.UU. los WSR-88D son de banda S, por lo que pueden duplicar el alcance en viento radial, respecto a una banda $C$, para la misma velocidad no ambigua.

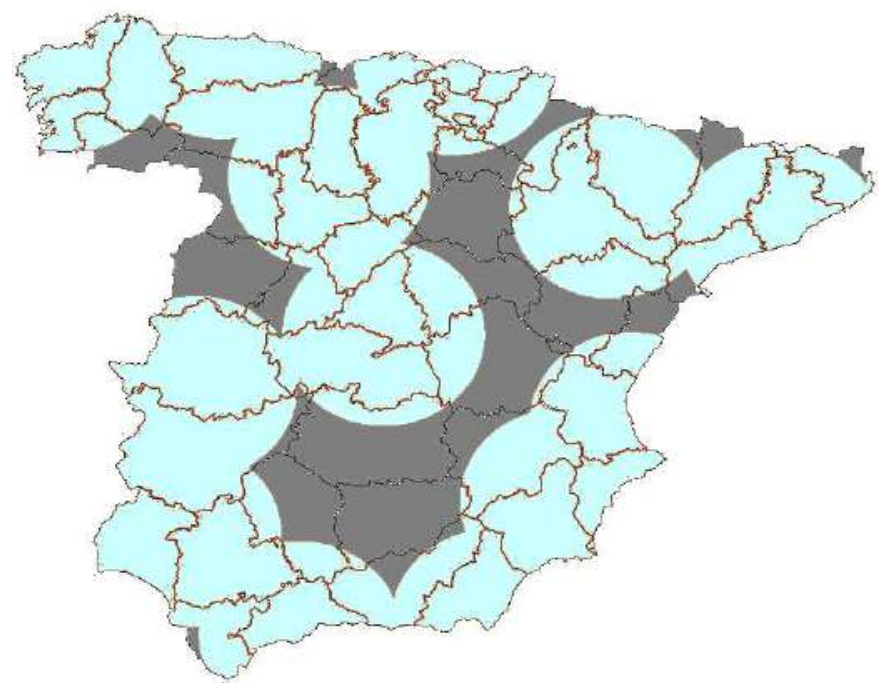

Figura 3.35. Cobertura espacial (en color azul) de la red de radares de AEMET en la España peninsular, para el producto viento radial Doppler. Las zonas en tonos grisáceos no son cubiertas por el sistema. Fuente: J.A. Quirantes, 2012.

Pero existe todavía otra circunstancia todavía mucho más limitante. En la estrategia de exploración corta de $120 \mathrm{~km}$, en la que se genera el producto de viento radial Doppler, sólo tenemos disponibles, en el mejor de los casos, dos elevaciones bajas: una elevación a 0.5ํㅗ (sistemáticamente) y otra de 1.4ำ (a petición). En la figura 3.36 se muestran solapados los haces de ambas elevaciones resaltados en amarillo, hasta $240 \mathrm{~km}$ de alcance, aunque realmente la exploración corta del viento radial sólo llega a $120 \mathrm{~km}$ (representada por una línea vertical continua de color negro). Hay que tener en cuenta que la anchura vertical del haz a $120 \mathrm{~km}$ de distancia es de $2 \mathrm{~km}$ aproximadamente, y a $240 \mathrm{~km}$, de $4 \mathrm{~km}$.

También en la figura 3.36 se representa como un cilindro rojo, la presencia del mesociclón bien en niveles bajos (izqda.), y en niveles medios (dcha.). Pues bien, existe una gran dificultad para localizar el mesociclón sólo con esas dos elevaciones del radar. En niveles bajos, entre 1 y $3 \mathrm{~km}$ por encima del radar, el mesociclón no puede localizarse aproximadamente cuando está situado a una distancia del radar entre 0 y $20 \mathrm{~km}$. En cambio el mesociclón en niveles medios (entre 3 y $6 \mathrm{~km}$ por encima del radar) no puede ser detectado a distancias aproximadas entre 0 y $75 \mathrm{~km}$ del radar, y sí a distancias entre 75 y $120 \mathrm{~km}$.

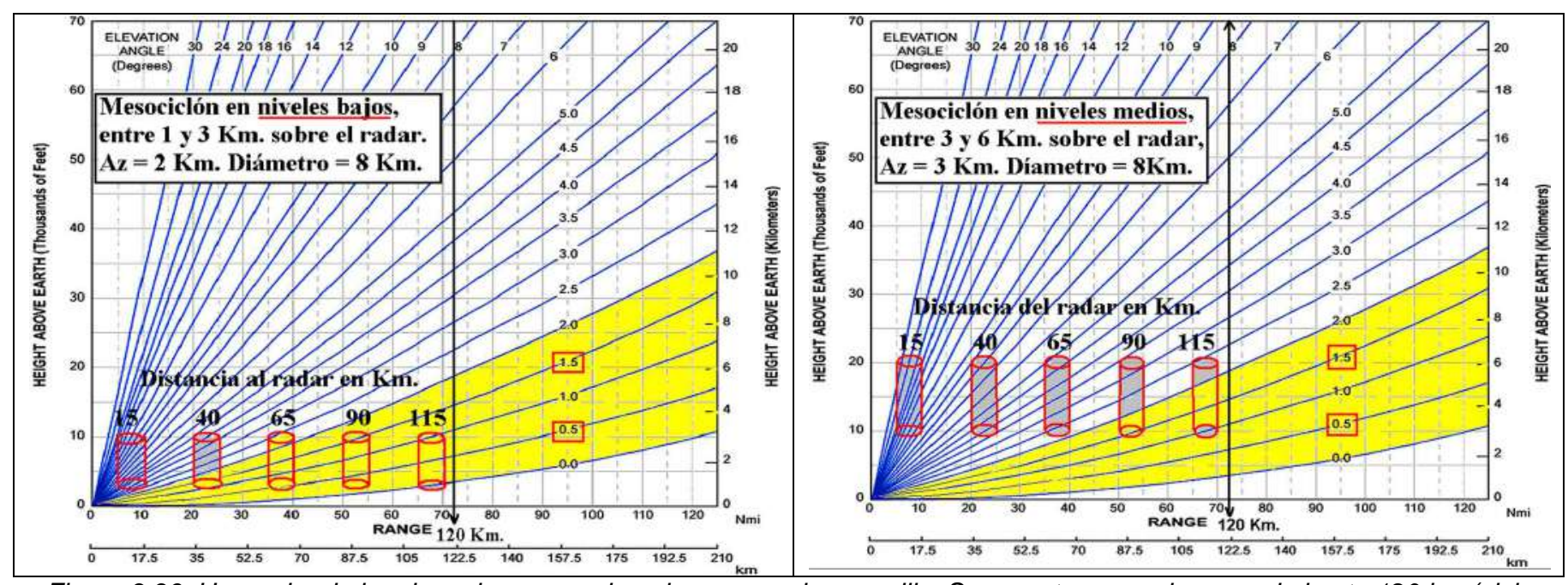

Figura 3.36. Haz radar de las dos primeras exploraciones en color amarillo. Se muestra para alcances de hasta $120 \mathrm{~km}$ (ciclo corto usado para generar el viento radial Doppler), cómo hay imposibilidad en algunas zonas de detectar un mesociclón, bien en capas bajas (izda), o en capas medias (dcha). Fuente: J.A. Quirantes, 2012. 
En consecuencia, la cobertura real de la red de radares de AEMET para detectar la existencia de un posible mesociclón queda muy reducida (figura 3.37). El mesociclón será localizable en capas bajas sólo cuando se encuentre entre 20 y $120 \mathrm{~km}$ del radar, y será localizable en capas medias sólo cuando se encuentre a una distancia del radar comprendida entre 80 y $120 \mathrm{~km}$.

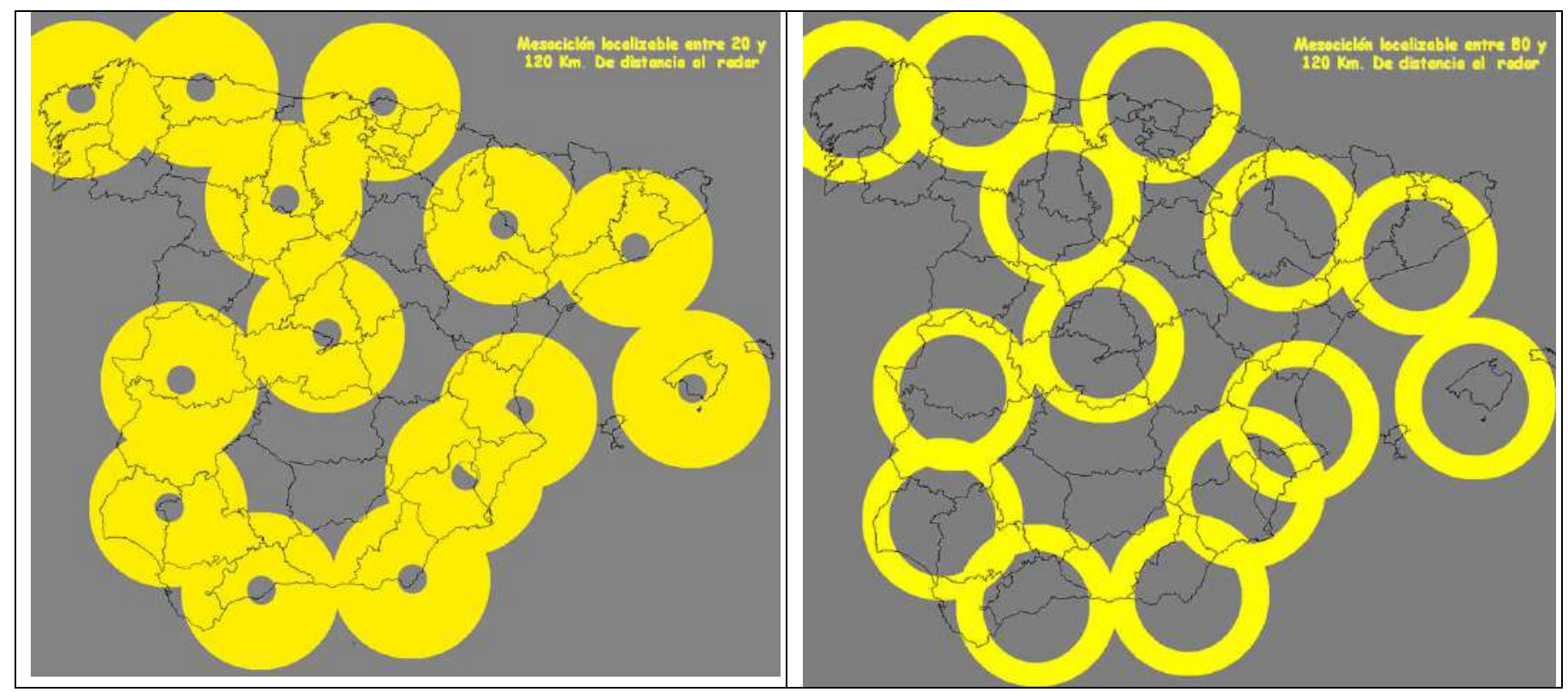

Figura 3.37. Cobertura real para detectar un mesociclón en capas bajas (izda.), o en capas medias (dcha.). Fuente: J.A. Quirantes, 2012.

Por lo tanto, es complicada la detección de un mesociclón en la red de radares de AEMET, más aún si tenemos en cuenta que sólo está disponible una única exploración de forma operativa para los vigilantes/predictores del Sistema Nacional de Predicción (la más baja, de elevación 0.5ํ) y además, de manera general, el producto viento radial Doppler presenta mucho ruido, con señales espurias. (Los PPI's de viento radial de elevaciones más altas, 1.4ำ $7.7^{\circ}$, etc., se podrían visualizar también, pero solicitándolos previamente, no de forma sistemática).

Por tanto, la continuidad temporal de la identificación del mesociclón durante varias imágenes consecutivas (cada 10 minutos) es una tarea muchas veces complicada o incluso imposible, aunque la supercélula esté realmente presente. En definitiva esto es debido, como se ha visto, a las ocultaciones que provoca en el haz del radar una orografía compleja, al movimiento de las supercélulas que hace que puedan pasar en poco tiempo de zonas de exploración adecuada a zonas ocultas por la táctica de exploración empleada con únicamente una o como mucho dos elevaciones del haz, y a la escasa duración, en bastantes ocasiones, del ciclo de vida de un mesociclón en España.

\subsection{3.- Características de las supercélulas identificadas por radar en España}

Un hecho clave para asegurar la existencia supercelular es la detección del mesociclón. Y para ello nada mejor y más objetivo que su identificación en el radar Doppler meteorológico, a partir de la observación del correspondiente giro mesoescalar en el viento radial. Es por tanto la detección del mesociclón persistente en radar una condición suficiente para catalogar a una tormenta como supercelular. Sin embargo frecuentemente es difícil detectar el mesociclón, sobre todo durante dos o más imágenes consecutivas, tal y como se ha comentado anteriormente. Recordemos que el intervalo temporal en el sistema radar actual es de 10 minutos entre dos imágenes sucesivas.

Así pues, si sólo tuviéramos en cuenta la identificación radar del mesociclón persistente como prueba irrefutable y única de la existencia de una supercélula, pocas veces en España podríamos identificar supercélulas. Por tanto, habrá que recurrir a la identificación de diversos patrones radar cuya coexistencia conjunta nos daría una media-alta confianza de que estamos ante una supercélula (por ejemplo la observación de ecos elevados e intensos, la zona de eco débil acotada, el gancho, un fuerte gradiente de reflectividad, el desvío respecto al viento medio rector, etc.). 
Es obvio, por tanto, que no se puede utilizar la detección del mesociclón en radar durante varias imágenes consecutivas como único elemento de confirmación supercelular, pues entonces podríamos llegar a la conclusión errónea de que tendríamos muy pocos casos de supercélulas en España. Por ello resulta muy interesante en gran número de episodios, contrastar la información radar con la observación visual para poder afirmar con alto grado de probabilidad la existencia de una supercélula.

Seguidamente, se muestran ejemplos de características de supercélulas a partir de la observación radar España. En la figura 3.38 se aprecia la típica estructura asociada a un mesociclón en el PPI de 0.5ํㅡㄴ (exploración más baja) del viento radial Doppler, identificándose el esquema del giro ciclónico mesoescalar.
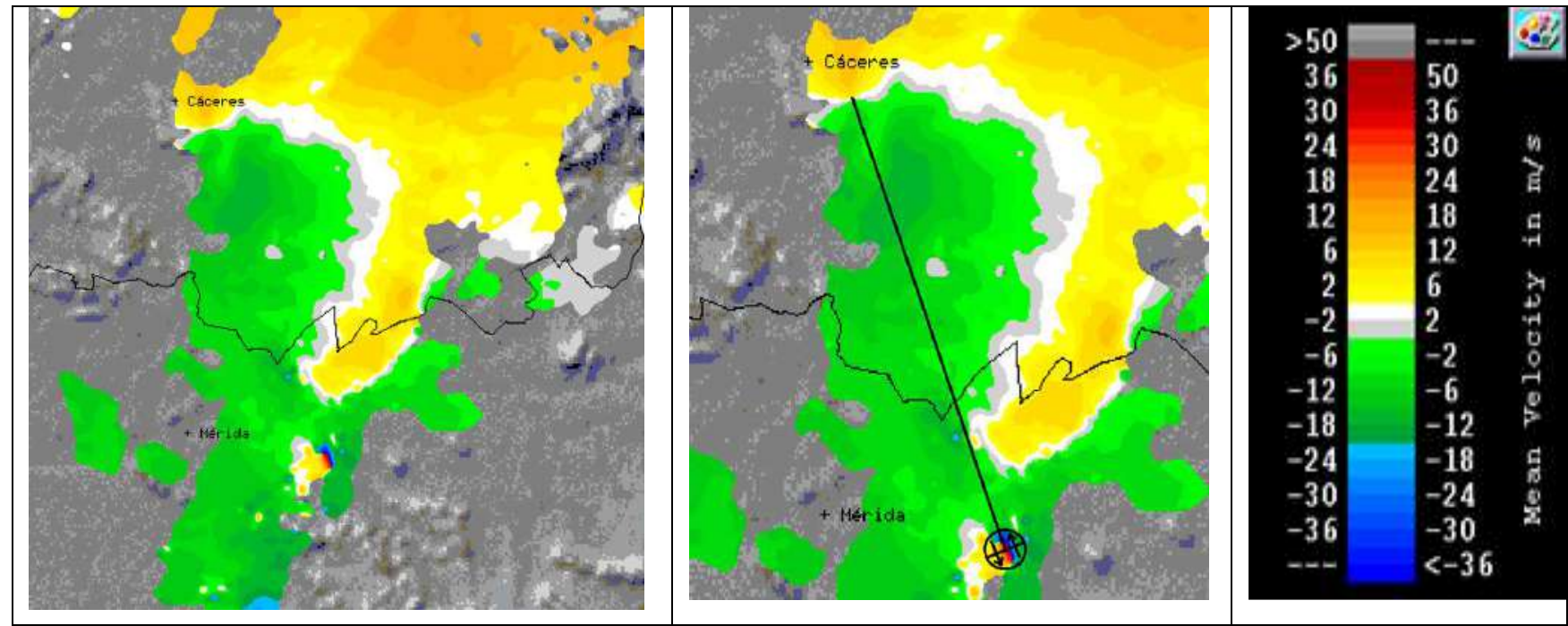

Figura 3.38. Izquierda: Identificación de un giro mesoescalar asociado a un mesociclón. Centro: análisis del giro debido a patrones contiguos de velocidades con sentidos opuestos a ambos lados de la dirección radial hacia el emplazamiento radar. Derecha: Escala de velocidades radiales en m/s. Fuente: J.A. Quirantes, 2012.

Ahora bien, si no se aprecia claramente un mesociclón persistente, habrá que recurrir a otros patrones típicos de supercélulas, para al menos poder tener una sospecha o una alta confianza en que la tormenta sea supercelular. En la figura 3.39 vemos el $P P I$ de reflectividad apreciándose claramente el gancho en la zona de alimentación en niveles bajos. Hay que tener en cuenta que en España, la gran mayoría de supercélulas son de giro ciclónico, pero un pequeño porcentaje tienen un giro anticiclónico, hablando en este caso de mesoanticiclón.

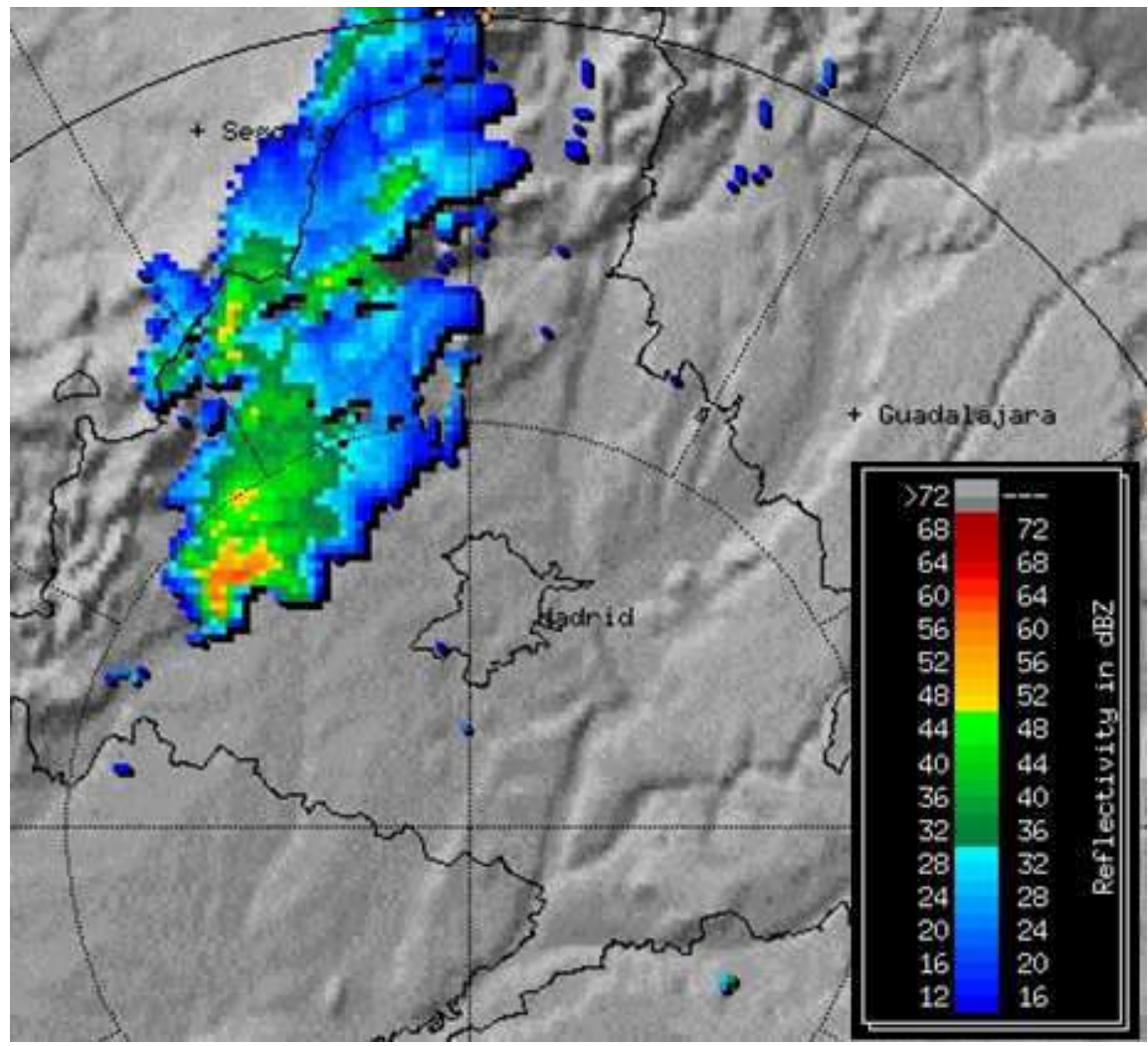

Figura 3.39. PPI de reflectividad en el que aparece claramente un gancho en la zona de alimentación de la tormenta en niveles bajos. 
Otro de los patrones que nos hace sospechar que estamos ante una supercélula, entre otros motivos, es la existencia de la zona de eco débil acotada $(B W E R)$, como se aprecia en la figura 3.40, y que también forma una especie de gancho vertical.

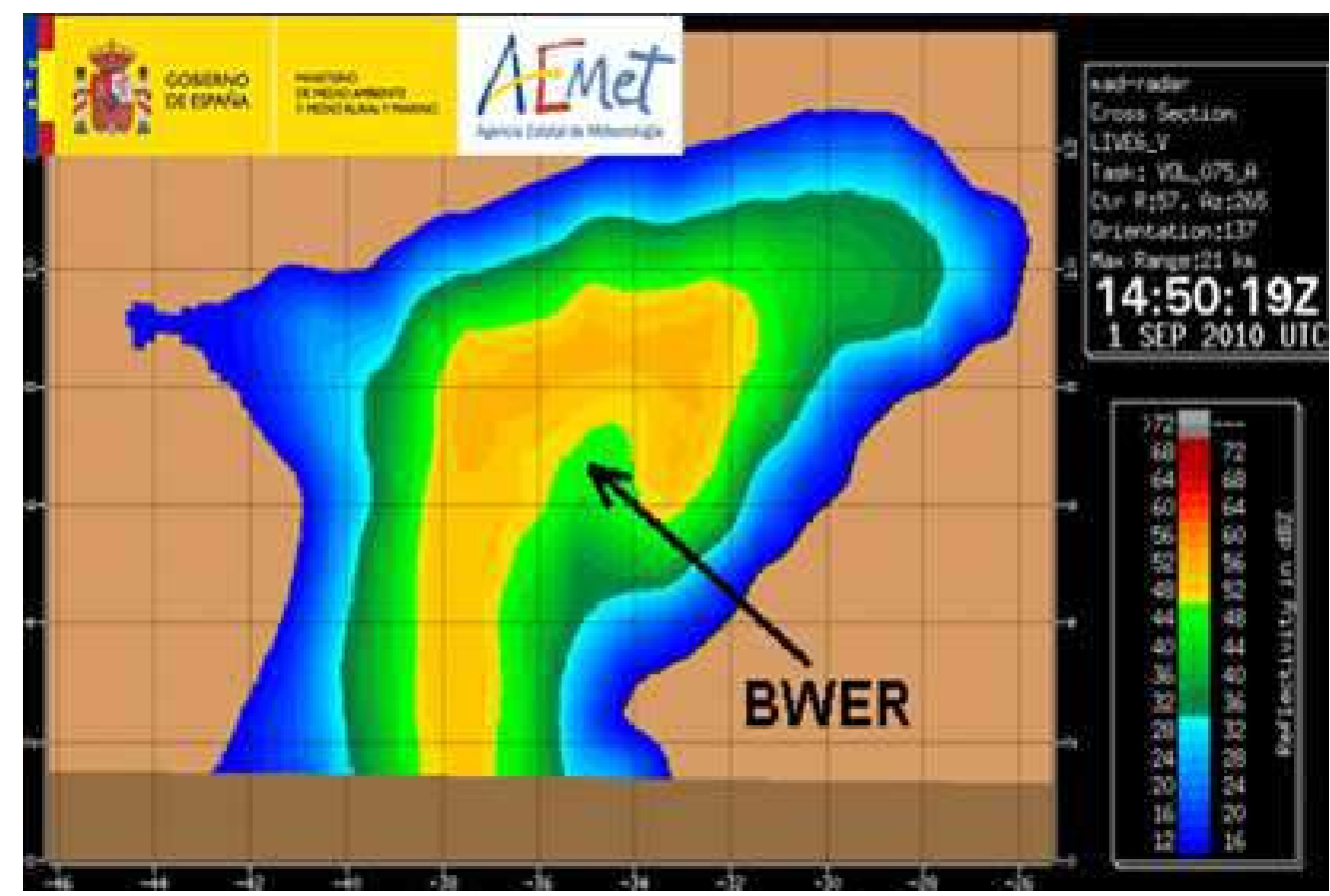

Figura 3.40. Corte vertical de reflectividad radar, en la que se aprecia la zona de eco débil acotada (BWER). Corresponde a la supercélula de Maqueda, Toledo, el 1 de septiembre de 2010. Ver figuras 3.14 y 3.26.

Fuente: J.A. Quirantes, 2012.

Si no observamos el mesociclón persistente en el radar (al menos durante 10 ó 20 minutos: 2 imágenes consecutivas), será por lo tanto la mayor o menor concurrencia de otros patrones típicos de supercélulas la que nos proporcionará una mayor o menor confianza sobre el carácter supercelular de la tormenta. Estos patrones ya han sido vistos anteriormente y serán de varios tipos dependiendo del método de observación o diagnóstico. Entre estos están los siguientes:

- Entornos meteorológicos de mesoescala propicios para la formación de supercélulas (convección intensa y valores elevados de cizalladura y helicidad relativa a la tormenta)

- Identificación visual (o fotografías o videos) de las estructuras nubosas típicamente asociadas a supercélulas (sacacorchos, cola de castor, nube pared, clear slot, etc.)

- Identificación de elementos típicos en radar: extensión e intensidad de ecos, gradiente de reflectividad, gancho, BWER, desvío de la trayectoria respecto al flujo rector en capas medias, stormsplitting (aunque no todos los storm-splitting producen supercélulas ni mucho menos todas las supercélulas proceden de un storm-splitting).

- Efectos severos en superficie. La mayor parte de casos de granizo de diámetro superior a $5 \mathrm{~cm}$ es de procedencia supercelular. No obstante, hay otras estructuras no supercelulares que pueden generar efectos severos similares a los de las supercélulas.

Por último conviene hacer una matización. Puede ser una buena praxis la "presunción de inocencia supercelular de una tormenta", más allá de las dudas razonables, hasta que no identifiquemos elementos inequívocamente supercelulares. Tampoco hay que olvidar que en España hay estructuras convectivas organizadas, no supercelulares, responsables por su gran frecuencia relativa de aparición, de la mayoría de los episodios de meteorología severa.

Es por ello que muchas veces no seremos capaces de asegurar categóricamente que una tormenta sea supercelular, aunque sospechemos con alta confianza que lo pueda ser... 


\section{4.- Casos de estudio}

En este apartado trataremos de poner de manifiesto los distintos grados de complejidad existentes a la hora de catalogar estructuras supercelulares en España.

Para ello se hará uso de dos distintas fuentes de información que en algunos casos proporcionarán un veredicto categórico sobre la naturaleza supercelular de la célula estudiada y en otros sólo unas conclusiones probabilísticas a tenor de los indicios disponibles.

\section{- Estructuras observables en fotos o videos de las nubes asociadas a la estructura convectiva}

Para un observador bien entrenado y con experiencia en identificación visual de fenomenología convectiva severa, la observación de las nubes asociadas a una supercélula se convierte en muchas ocasiones en prueba irrefutable de su carácter supercelular.

No obstante es imposible que haya un seguimiento visual de todas y cada una de las supercélulas que se producen, y además en muchos casos no se pueden observar de la mejor manera posible, quedando dudas en su catalogación.

Por último, a veces la visualización a posteriori de distintas fotos y videos de una tormenta puede ser de gran ayuda para estimar la probabilidad de que una tormenta haya sido supercelular.

\section{- Patrones detectables en el radar Doppler}

Algunas estructuras identificables a través de productos radar de reflectividad, ya comentadas previamente, pueden convertirse por sí mismas en indicios o sospechas de posible o probable estructura supercelular. La identificación del mesociclón (mesoanticiclón) persistente en el viento radial Doppler es condición suficiente para la caracterización supercelular, aunque a veces sea una tarea complicada por varios motivos anteriormente citados. En la práctica la observación visual de la estructura supercelular o la identificación radar del mesociclón, ambos elementos potencialmente concluyentes por separado, son a veces difíciles de llevar a cabo, y en consecuencia se debe hablar de la hipotética o presunta naturaleza supercelular de una estructura convectiva.

A continuación se estudiarán varios casos de supercélula (o probable supercélula), caracterizados de manera esquemática por situaciones suficientemente representativas que tratan de representar a gran parte del conjunto de episodios típicos que suelen aparecer en España. Para ello se utilizará la caracterización meteorológica básica del entorno y se pondrán imágenes de radar y/o fotografías que sirven para establecer una probabilidad (o certeza) sobre la presencia de una supercélula.

En la caracterización meteorológica se incluyen valores de varios parámetros básicos, obtenidos a partir de la simulación del modelo del ECMWF en el entorno donde se ha producido la tormenta.

- Energía Potencial Convectiva Disponible desde una capa promedio de los primeros $100 \mathrm{hPa}(C A P E)$,

- Energía Potencial Convectiva Disponible desde superficie (SBCAPE),

- Cizalladura en la capa de los primeros $6 \mathrm{~km}(\mathrm{ClZ6})$ y

- Helicidad relativa a la tormenta en los primeros $3 \mathrm{~km}$.

No obstante ya se ha comentado que existen mecanismos locales generadores de helicidad relativa a la tormenta, que no son en absoluto bien simulados por los modelos numéricos, incluso en entornos con valores de cizalladura ambiental inferior a la normalmente exigible. 


\section{A.- Supercélula en Madrid el 6 de mayo de 2011 a 18:50 UTC}

En esta ocasión ya existía previamente un entorno ambiental muy favorable para la formación de supercélulas, con convección profunda organizada y altos valores de helicidad relativa a la tormenta. Pero la clave es la detección del mesociclón en radar, que confirma la presencia supercelular. Además se identifican visualmente patrones típicamente asociados a las supercélulas.

\section{Entorno convectivo:}

Los parámetros más significativos en el entorno de la tormenta fueron nítidamente favorables.

\begin{tabular}{|c|c|c|c|c|}
\hline & $C A P E(\mathrm{~J} / \mathrm{kg})$ & $S B C A P E(\mathrm{~J} / \mathrm{kg})$ & $C / Z 6(\mathrm{~m} / \mathrm{s})$ & $S R H 3\left(\mathrm{~m}^{2} / \mathrm{s}^{2}\right)$ \\
\hline Valores & 100 & 589 & 14 & 122 \\
\hline
\end{tabular}

\section{Imágenes radar:}

En la figura 4.1 se puede identificar tanto el gancho en la imagen $P P I$ de reflectividad, como el mesociclón en el PPI de viento radial. Además se presenta un zoom del mesociclón detectado en el radar de Madrid.
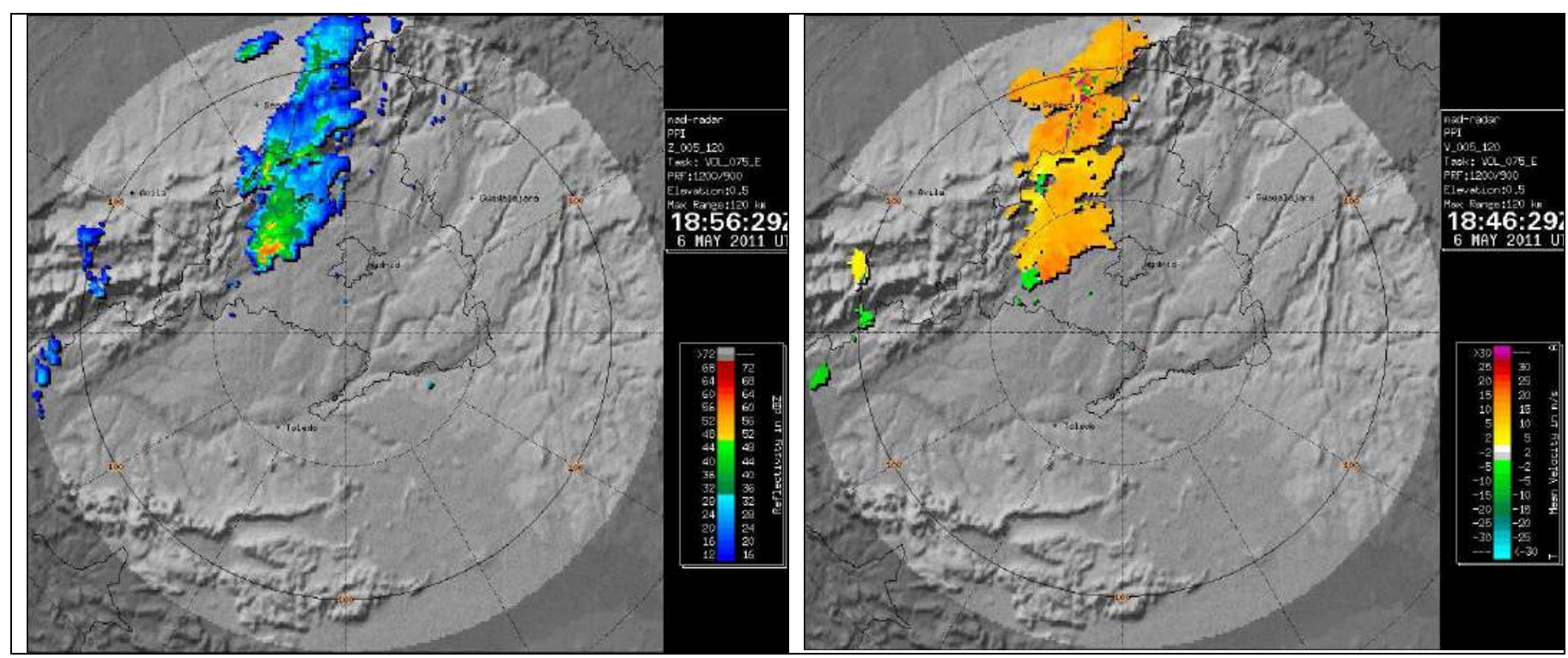

Figura 4.1. Izquierda: PPI de reflectividad del radar de Madrid. Derecha: Viento radial radar.

El mesociclón se observa al menos durante 3 imágenes consecutivas, como sugiere la figura 4.2.

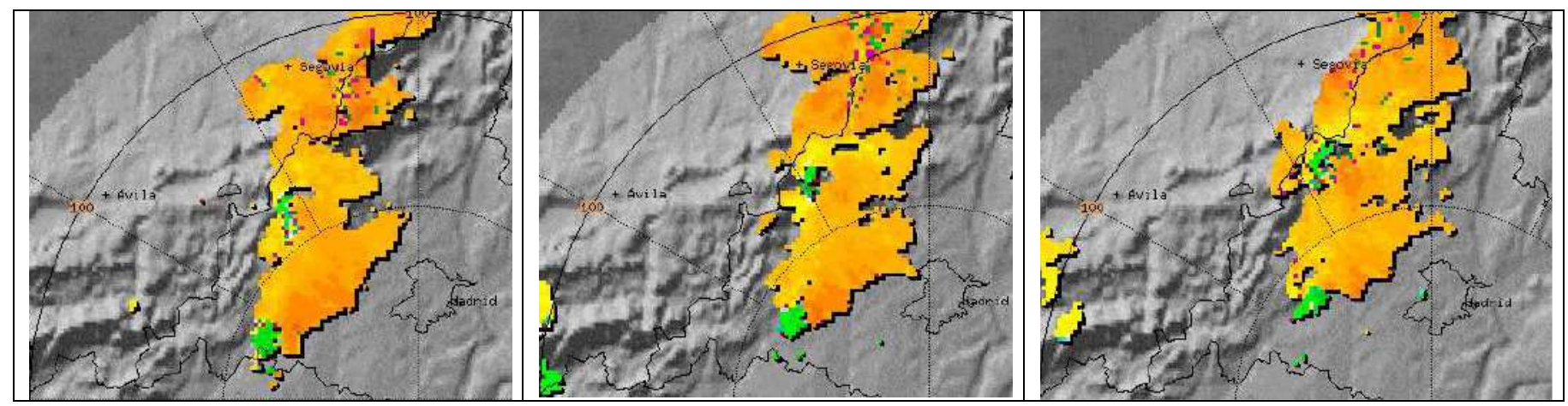

Figura 4.2: Izquierda: PPI de viento radial a 18:36, 18:46 y 18:56 UTC, en las que se identifica el mesociclón

El mesociclón se muestra en detalle en la figura 4.3, en la que el giro se manifiesta en el viento radial, con colores cálidos alejándose del radar y colores fríos acercándose. 


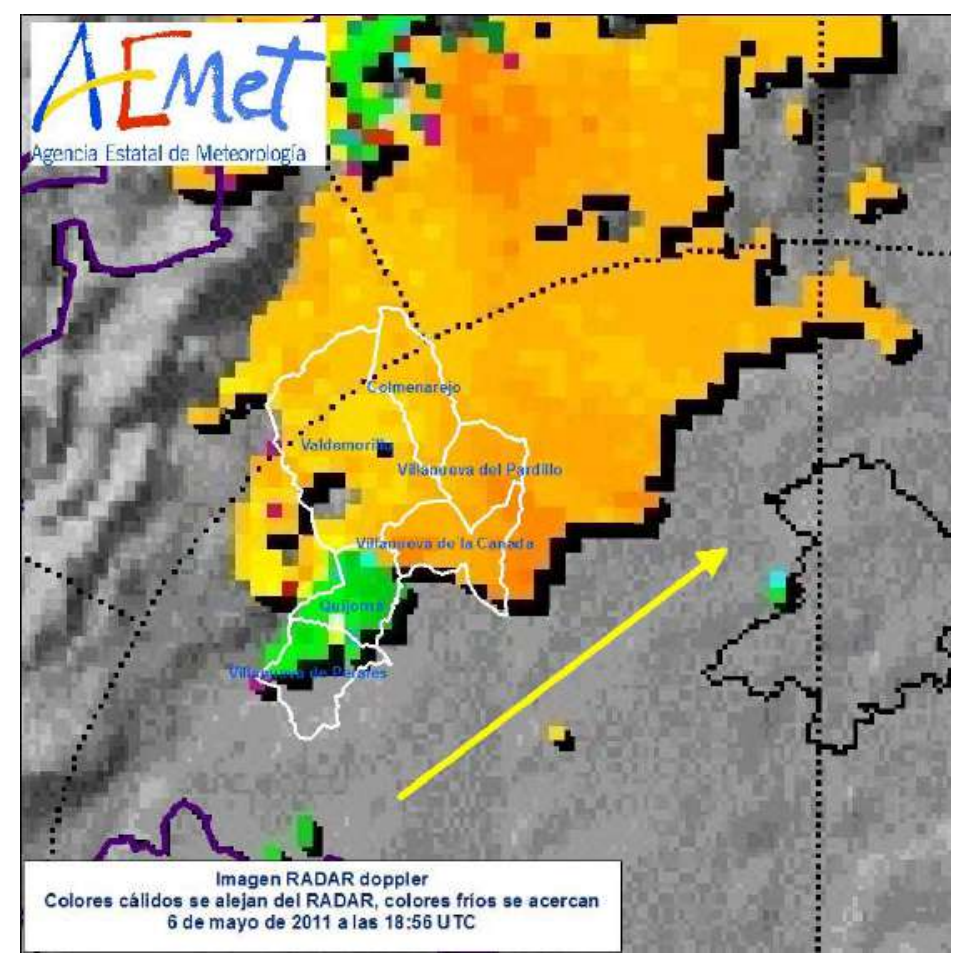

Figura 4.3: Detalle del mesociclón en el viento radial Doppler del 6 de mayo de 2011 a 18:56 UTC.

La flecha amarilla indica el desplazamiento de la célula.

Por otra parte la reflectividad máxima superó los 63 dBZ y el echotop alcanzó los14km.

Foto:

En la siguiente imagen (figura 4.4) su autor, J. A. Quirantes, ha detallado sobre la foto de la tormenta, algunos de los elementos nubosos típicos de una a supercélula, que concurrieron en esta situación.

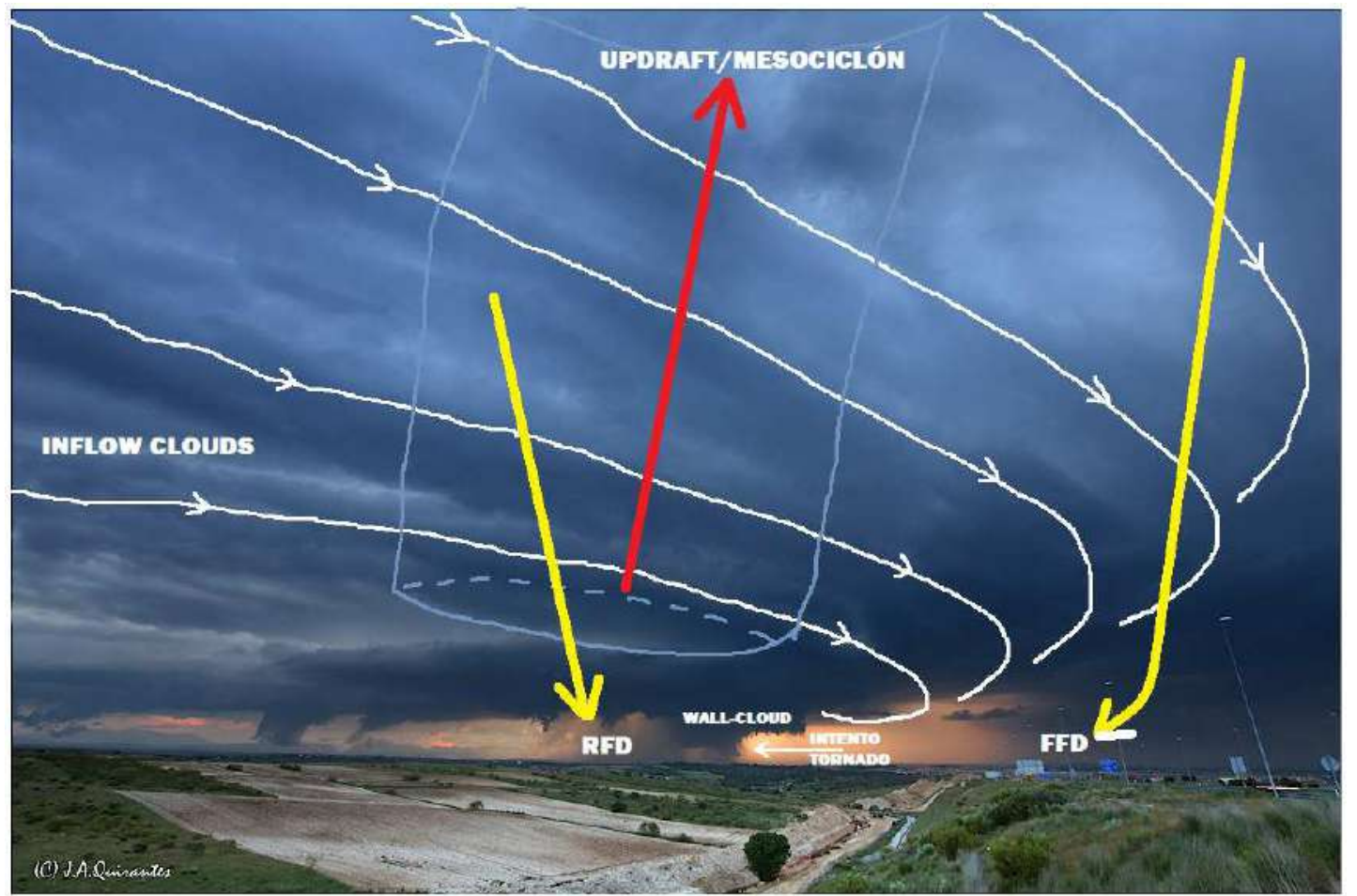

Figura 4.4: Foto de la supercélula de Madrid, del 6 de mayo de 2011, con identificación de elementos básicos.

Fuente: J.A. Quirantes, 2012. http://foro.tiempo.com/supercelula-americana-a-25-km-de-la-puerta-del-sol-madrid-6mayo2011$\underline{t 131853.0 . h t m l}$

En esta situación todo parece bastante evidente. En un entorno meteorológico favorable para supercélulas se ha formado una tormenta con destacable aparato eléctrico que ha desarrollado un mesociclón fácilmente identificable en las imágenes radar. Aunque esto último es concluyente por sí mismo, además visualmente la nube presenta las características propias de una supercélula. Por tanto se puede concluir que estamos ante un caso en el que no hay dudas de que se trató de una supercélula, y además similar a las típicas de las llanuras americanas. 


\section{B.- Tormenta del 12 de mayo de 2013 en Caudete (Valencia)}

En este episodio se identifican elementos muy determinantes que hacen sospechar casi con certeza que estamos ante una supercélula.

\section{Entorno convectivo:}

La tormenta se desarrolló en un entorno ambiental en el que concurrían valores de CAPE y cizalladura superando o casi alcanzando sus respectivos umbrales de referencia según la predicción del modelo del ECMWF. No ocurría lo mismo con la helicidad relativa a la tormenta en los primeros $3 \mathrm{~km}$, aunque como hemos comentado este hecho no es un impedimento para que localmente pudieran haber existido valores muy superiores en la realidad.

\begin{tabular}{|c|c|c|c|c|}
\hline & CAPE $(\mathrm{J} / \mathrm{kg})$ & SBCAPE $(\mathrm{J} / \mathrm{kg})$ & $\mathrm{ClZ6}(\mathrm{m} / \mathrm{s})$ & $S R H 3\left(\mathrm{~m}^{2} / \mathrm{s}^{2}\right)$ \\
\hline Valores & 32 & 235 & 8 & 34 \\
\hline
\end{tabular}

\section{Imágenes radar:}

La tarde del día 12 de mayo de 2013 se produjo una tormenta en el interior norte de la provincia de Valencia que puntualmente llevó aparejados fenómenos de tipo severo en superficie, como granizo y precipitaciones de intensidad muy fuerte en la zona de Caudete de las Fuentes.

El patrón clásico de muchas de las tormentas que se generan en el interior de la Comunidad Valenciana en primavera y verano va unido al modelo conceptual de brisa, ya que es la brisa la que en muchas ocasiones actúa como mecanismo de disparo de la inestabilidad termodinámica por la convergencia de aire en capas bajas a partir de mediodía debido a la llegada del frente de brisa al interior montañoso de las provincias de Castellón y Valencia.

Al analizar los productos radar, se observa cómo la tormenta proviene de la provincia de Cuenca en forma de estructura no-supercelular, moviéndose de oeste a este. Sin embargo, al adentrase en la provincia de Valencia se hace evidente un fuerte desvío anómalo del movimiento de la estructura convectiva, de norte a sur, pasando por la comarca de Utiel-Requena, a pesar de que el flujo general implicaría un movimiento de oeste a este. Al analizar los vientos del modelo en superficie, se observa como una mesoalta situada en el Mar Balear genera vientos del SE en la provincia de Valencia (mientras que en la de Cuenca eran del WSW). Este hecho, probablemente, bastó por si solo para que se modificara drásticamente la helicidad relativa a la tormenta, aumentando considerablemente el valor de $\mathrm{SRH} 3$ y creando un marco idóneo para la formación de una supercélula en esa zona.

Coincidiendo en espacio y tiempo con la zona donde se reportaron fenómenos severos asociados a la convección (intensidad de precipitación muy fuerte con acumulados superiores a $30 \mathrm{l} / \mathrm{m}^{2}$ en menos de una hora y gran cantidad de granizo de tamaño pequeño), se observó una alta densidad de rayos positivos a la vez que la célula convectiva iniciaba la fase de colapso. (Estrictamente, según la NOAA, las precipitaciones intensas no son un fenómeno severo).

Por otra parte se observa también una estructura en forma de gancho en la imagen de PPI de reflectividad (figura 4.5), y es posible la detección de un mesociclón en el viento radial (figura 4.6).

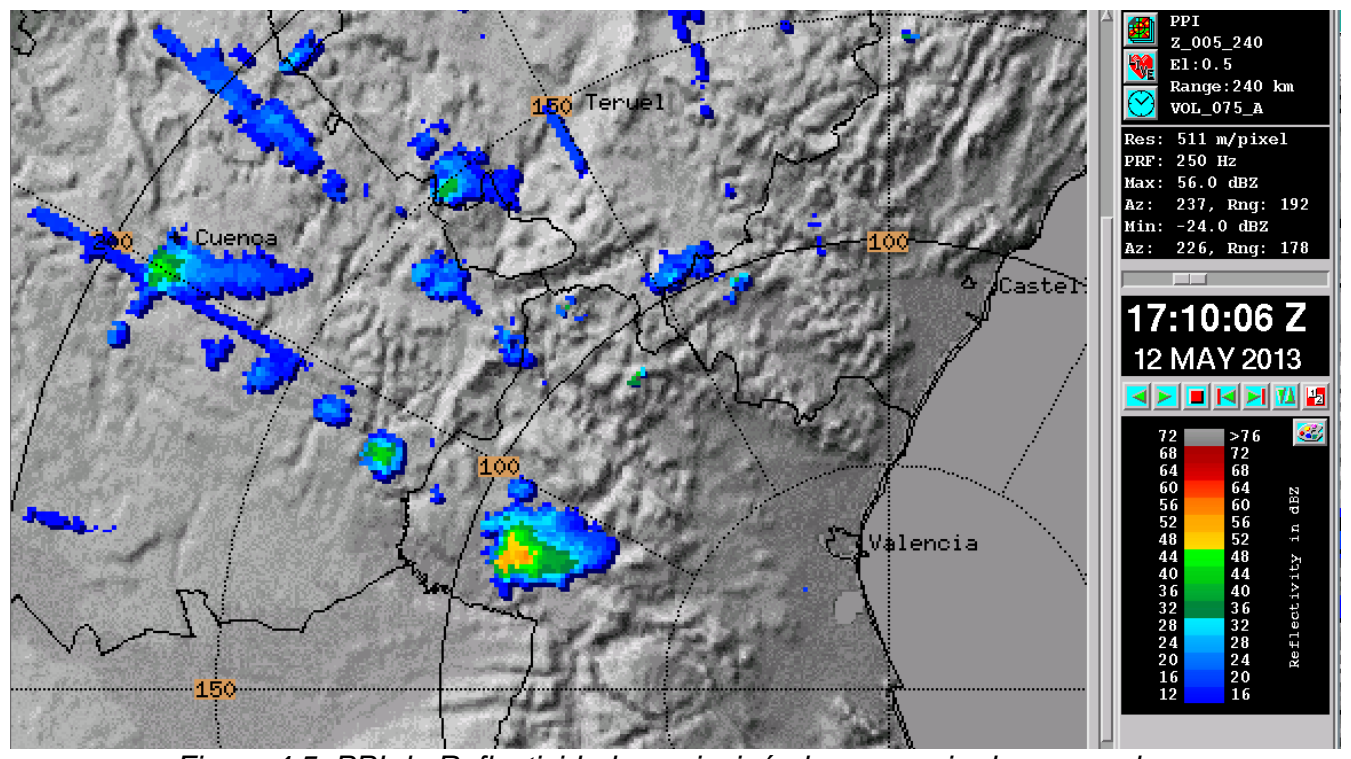

Figura 4.5: PPI de Reflectividad, que insinúa la presencia de un gancho. Radar de Valencia el 12 de mayo de 2013 a 17:10 UTC

Características básicas de las supercélulas en España. Página - 47 - 


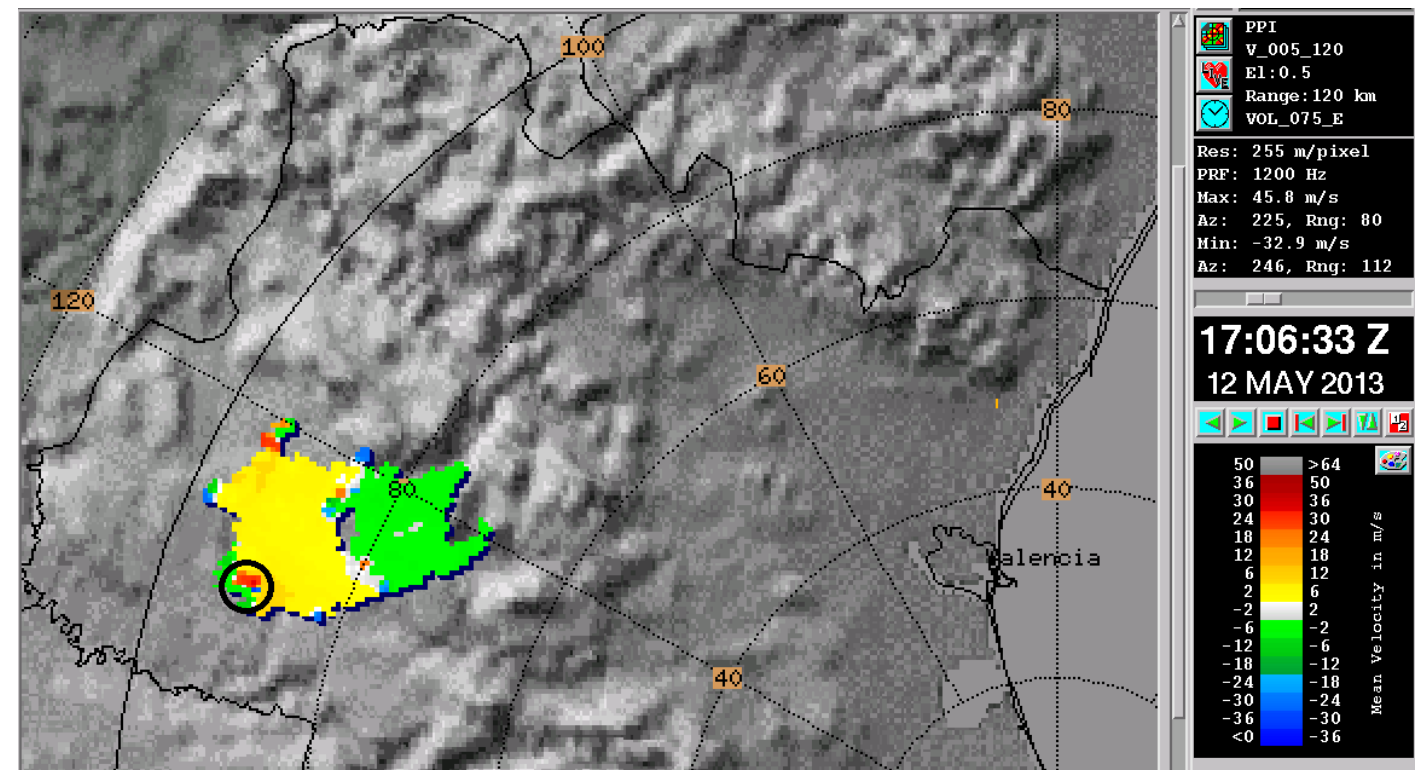

Figura 4.6: Ecos cálidos (color rojo) y fríos (color verde) enfrentados en el viento radial Doppler, denotando la existencia de un giro mesoescalar compatible con la existencia de mesociclón. Radar de Valencia, 12 de mayo de 2013 a 17:06 UTC

Fotos:

En la figura 4.7 se presenta una imagen que muestra una probable estructura supercelular, hipótesis refrendada más categóricamente por el video time lapse que se puede encontrar en el siguiente enlace:

http://www.youtube.com/watch?v=fwDnrVVDUbU\&feature=youtu.be

Además, hay imágenes adicionales que se pueden encontrar en http://foro.tiempo.com/casos-de-presuntassupercelulas-en-espana-en-2013-normas-y-listado-pagina-1-t140019.48.html

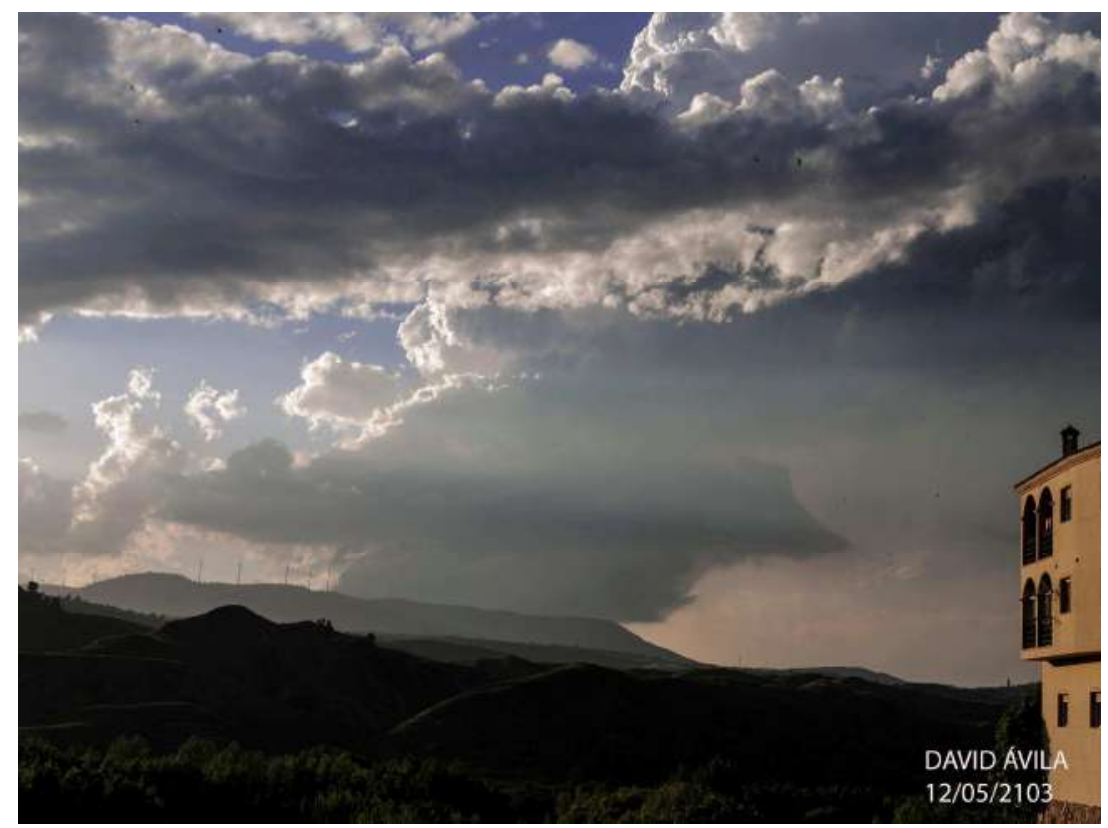

Figura 4.7: Fotos de la tormenta en Caudete (Valencia), del 12de mayo de 2013.

Fuente: David Ávila. Foro de Meteored.

Este es un típico ejemplo de la observación y catalogación de supercélulas en España. Se trata de una tormenta de una única célula que es persistente, con un desvío anómalo muy claro, reflectividades altas mantenidas, existencia de un gancho en la reflectividad, con disponibilidad de fotos o videos que muestran elocuentemente rasgos supercelulares. Sin embargo la traza del mesociclón en el viento radial doppler aparece con una señal poco llamativa. También, como en este caso, en muchas situaciones supercelulares los valores ambientales de helicidad relativa a la tormenta simulados por los modelos no son demasiado significativos, aunque a nivel local sí que se habría producido probablemente un incremento notable de los mismos.

Por todo lo anterior se puede decir que parece que estamos ante una supercélula, aunque en este caso la apariencia es mucho menos espectacular que la de las supercélulas de las llanuras de Estados Unidos. 


\section{C.- Tormenta 26 agosto de 2013 en Sierra de María (Almería)}

El entorno meteorológico general no era a priori el más favorable para la posible aparición de supercélulas, porque aunque la inestabilidad sí es grande, la cizalladura no es demasiado alta, aparte de que la helicidad relativa simulada por los modelos es poco acusada. No obstante en el radar se observa un storm-splitting que fue vital en este caso para determinar el presunto carácter superceulular de la estructura.

\section{Entorno convectivo:}

La tormenta se desarrolló en un entorno con los siguientes parámetros ambientales

\begin{tabular}{|c|c|c|c|c|}
\hline & $C A P E(\mathrm{~J} / \mathrm{kg})$ & $S B C A P E(\mathrm{~J} / \mathrm{kg})$ & $C / Z 6(\mathrm{~m} / \mathrm{s})$ & $S R H 3\left(\mathrm{~m}^{2} / \mathrm{s}^{2}\right)$ \\
\hline Valores & 660 & 1300 & 7 & 33 \\
\hline
\end{tabular}

\section{Imágenes radar:}

Se produce un storm-splittng hacia las 11:10 UTC, aproximadamente, en el que finalmente la célula de la derecha (right mover) parece convertirse en una supercélula ciclónica. En la secuencia de la figura 4.8 vemos la evolución de esa célula desde la confluencia de las provincias de Jaén, Albacete, Murcia, Granada y Almería, a partir de donde realiza un desplazamiento muy anómalo, desviándose muy claramente del viento medio del noroeste y dirigiéndose hacia el suroeste.

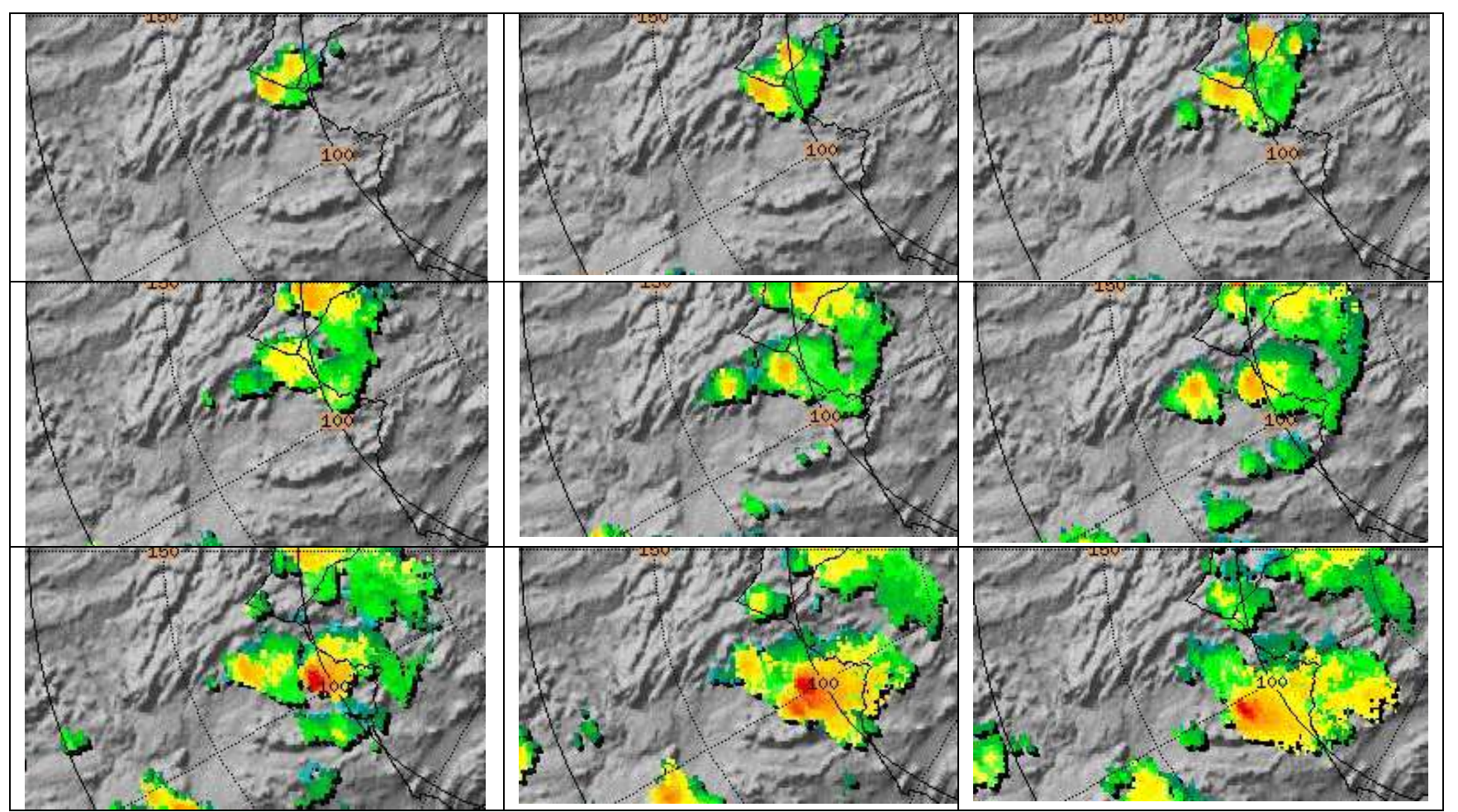

Figura 4.8: Imágenes del echotop $(\mathrm{km})$ del radar de Murcia durante la tarde del 26 de agosto de 2013.

Se presentan imágenes cada 20 minutos desde las 13:00 UTC, ordenadas temporalmente de izquierda a derecha y posteriormente de arriba abajo.

En la figura 4.9 (arriba) se presenta la célula a partir del producto de reflectividad máxima del radar de Almería. Los ecos son muy intensos (máximos del orden de de $60 \mathrm{dBZ}$ ) y profundos (llegando el echotop hasta 15 $\mathrm{km}$ ), con una extensión horizontal significativa. En la parte de abajo de la propia figura 4.9, se insinúa la presencia de un mesociclón mantenido en el tiempo.

Es también preciso constatar el hecho de que se registró pedrisco de gran tamaño (superior a $4 \mathrm{~cm}$ ), como se puede observar en la figura 4.11 . 

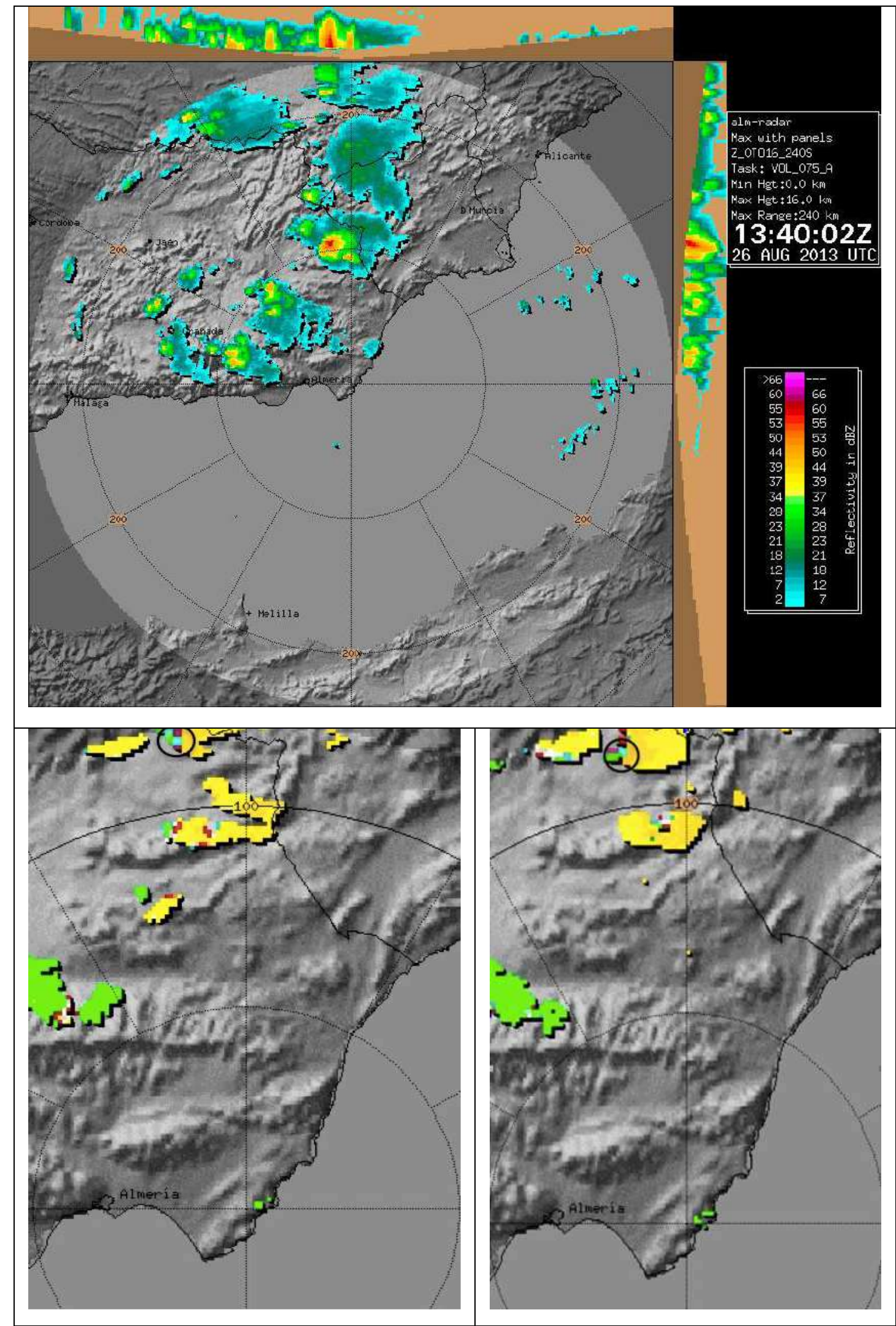

Figura 4.9: (Arriba) Imagen de reflectividad máxima del radar de Almería a las 13:40 UTC del 26 de agosto de 2013.

(Abajo) Localización del patrón identificativo del mesociclón (resaltado con un círculo) en el viento radial Doppler del radar de Almería, en dos imágenes consecutivas a 13:06 y 13:16 UTC 
Fotos:

La imagen de la nube que se adjunta (figuras 4.10a y 4.10b), fotografiada en la zona, no permite constatar plenamente, aunque se atisba, una posible estructura supercelular.

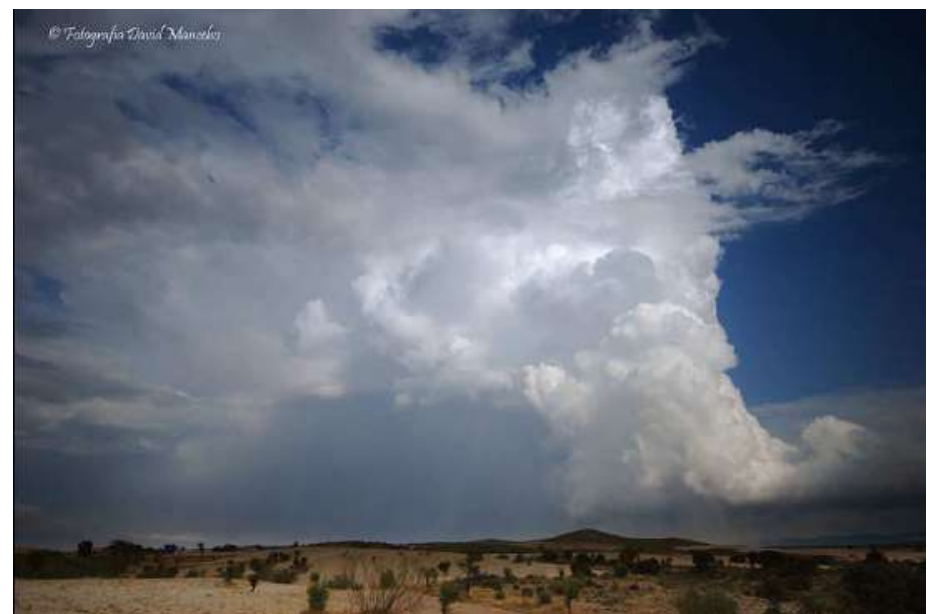

Figura 4.10a. Foto de la estructura tormentosa en el norte de la provincia de Almería, el 26 de agosto de 2013.

Fuente: David Mancebo Atienza. Foro de Meteored.

http://foro.tiempo.com/casos-de-presuntas-supercelulas-en-espana-en-2013-normas-y-listado-pagina-1-t140019.540.html

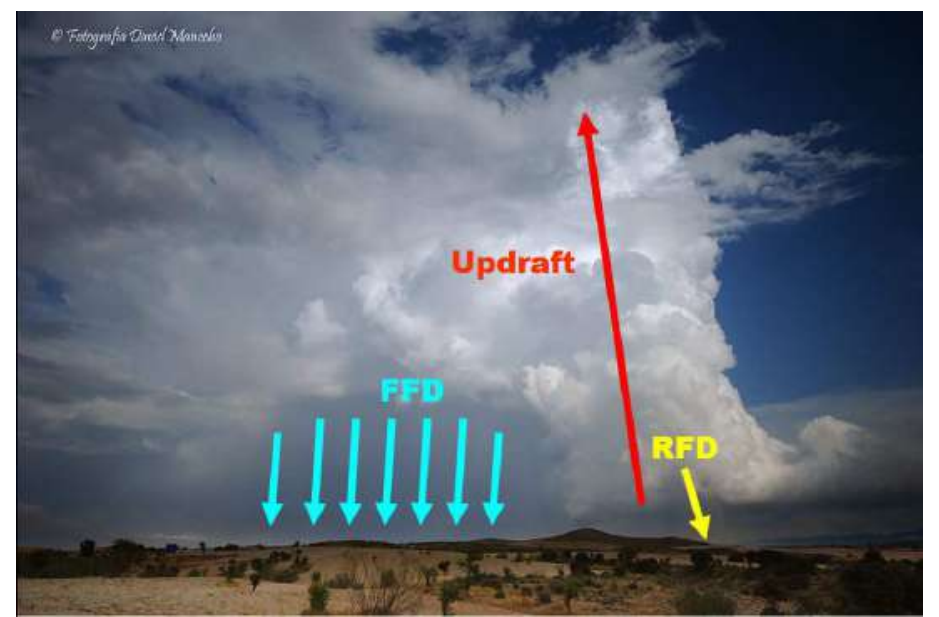

Figura 4.10b. Posible situación de las tres corrientes supercelulares (Updraf", FFD y RFD) de la figura 4.10a

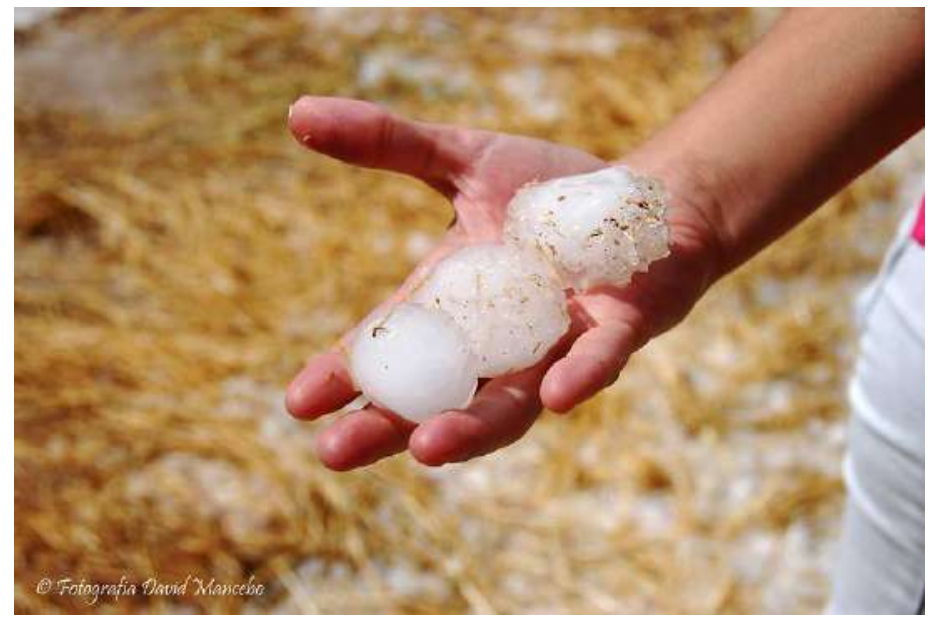

Figura 4.11. Piedras de granizo de $4 \mathrm{~cm}$ de diámetro que produjo la supercélula. Foto @ David Mancebo Atienza.

La estructura de este caso surge en un entorno con gran inestabilidad, a partir de un storm-splitting en la que la célula de la derecha se intensifica y mueve de manera muy anómala a la derecha del viento medio, persistiendo durante bastante tiempo con valores de reflectividad muy altos. En el viento radial del radar (elevación de 1.5) parece adivinarse la existencia de un mesociclón. La foto de la nube disponible no es del todo concluyente, aunque parecen adivinarse las tres corrientes características de una supercélula y además se recogió granizo de tamaño muy grande (fig. 4.11). Por consiguiente, también en esta situación parece que estamos ante un caso típico de supercélula en España.

Características básicas de las supercélulas en España. Página - 51 - 


\section{D.- Tormenta del 3 de octubre de 2013 en Albacete}

El entorno meteorológico era claramente idóneo para la generación de supercélulas. Sin embargo esa zona queda fuera de la cobertura del viento radial Doppler de cualquier radar y por tanto no se puede identificar el mesociclón a partir de datos de teledetección. Además, no existen fotografías concluyentes acerca de las características de la estructura nubosa de la tormenta.

La tormenta produjo precipitaciones intensísimas a su paso por la Base Aérea de Albacete, dejando 55 $\mathrm{mm}$ en 20 minutos y una racha de viento superior a $100 \mathrm{~km} / \mathrm{h}$. También la célula convectiva produjo durante su ciclo de vida, granizo de tamaño grande y un notable aparato eléctrico.

\section{Entorno convectivo:}

La tormenta se desarrolló con los siguientes parámetros propios de entornos favorables para supercélulas

\begin{tabular}{|c|c|c|c|c|}
\hline & CAPE $(\mathrm{J} / \mathrm{kg})$ & $\operatorname{SBCAPE}(\mathrm{J} / \mathrm{kg})$ & $C I Z 6(\mathrm{~m} / \mathrm{s})$ & $S R H 3\left(\mathrm{~m}^{2} / \mathrm{s}^{2}\right)$ \\
\hline Valores & 380 & 668 & 11 & 128 \\
\hline
\end{tabular}

\section{Imágenes radar:}

En el producto echotop (que llegó a superar los $15 \mathrm{~km}$ ) de la exploración de largo alcance del radar de Valencia (figura 4.12), se puede identificar una estructura convectiva extensa y de gran desarrollo vertical. La célula, que tuvo un ciclo de vida superior a dos horas, se desplazó con bastante rapidez desde el suroeste hacia el nordeste.

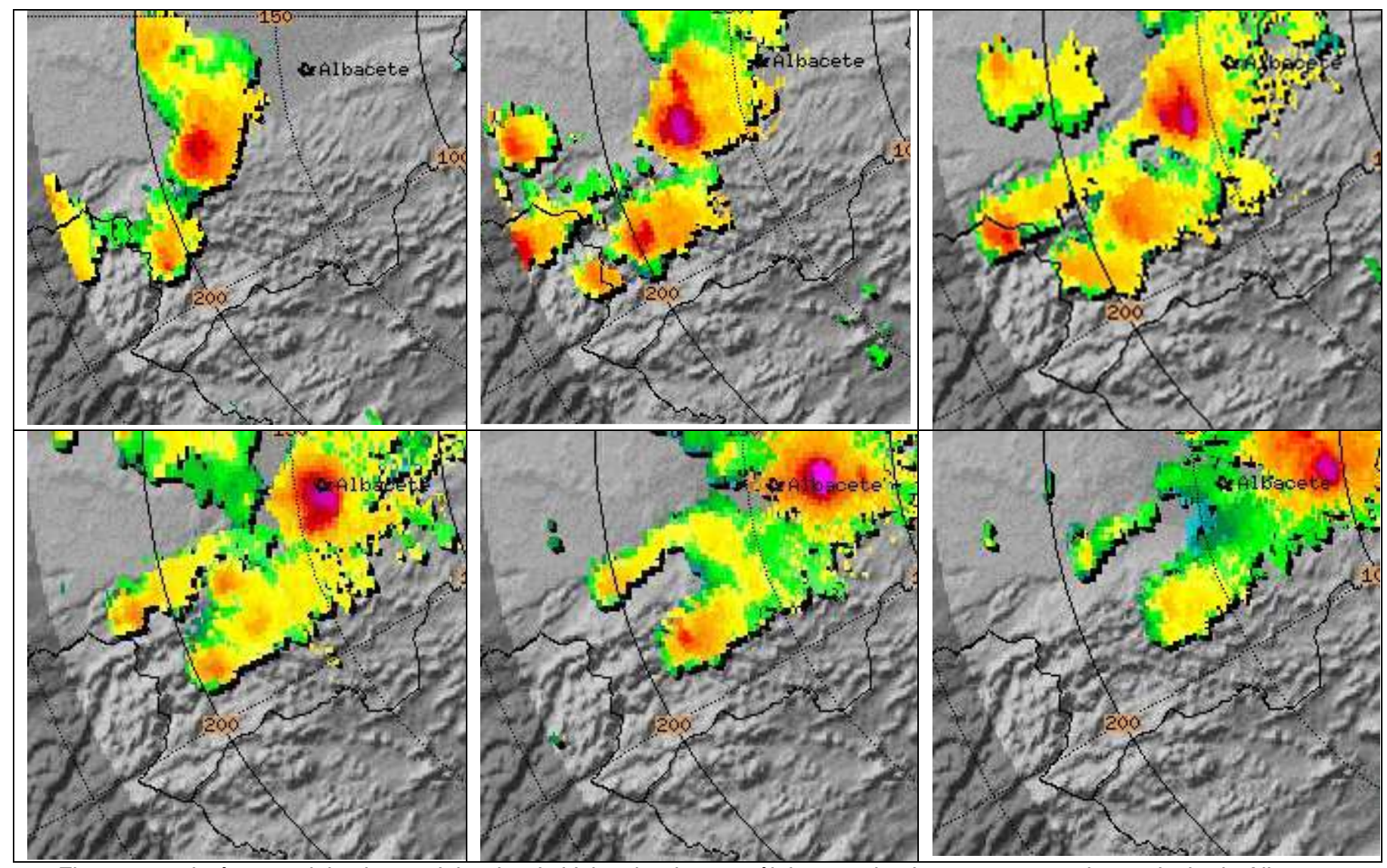

Figura 4.12: Imágenes del echotop del radar de Valencia, de una célula organizada a su paso por la provincia de Albacete, durante la tarde del 3 de octubre de 2013. Se presentan imágenes cada 20 minutos desde la 15:00 UTC

En la figura 4.13 se presenta el producto de reflectividad máxima a las 16:00 UTC, justo al pasar la célula rozando la ciudad de Albacete. Los valores máximos superaron el umbral de $60 \mathrm{dBZ}$. 


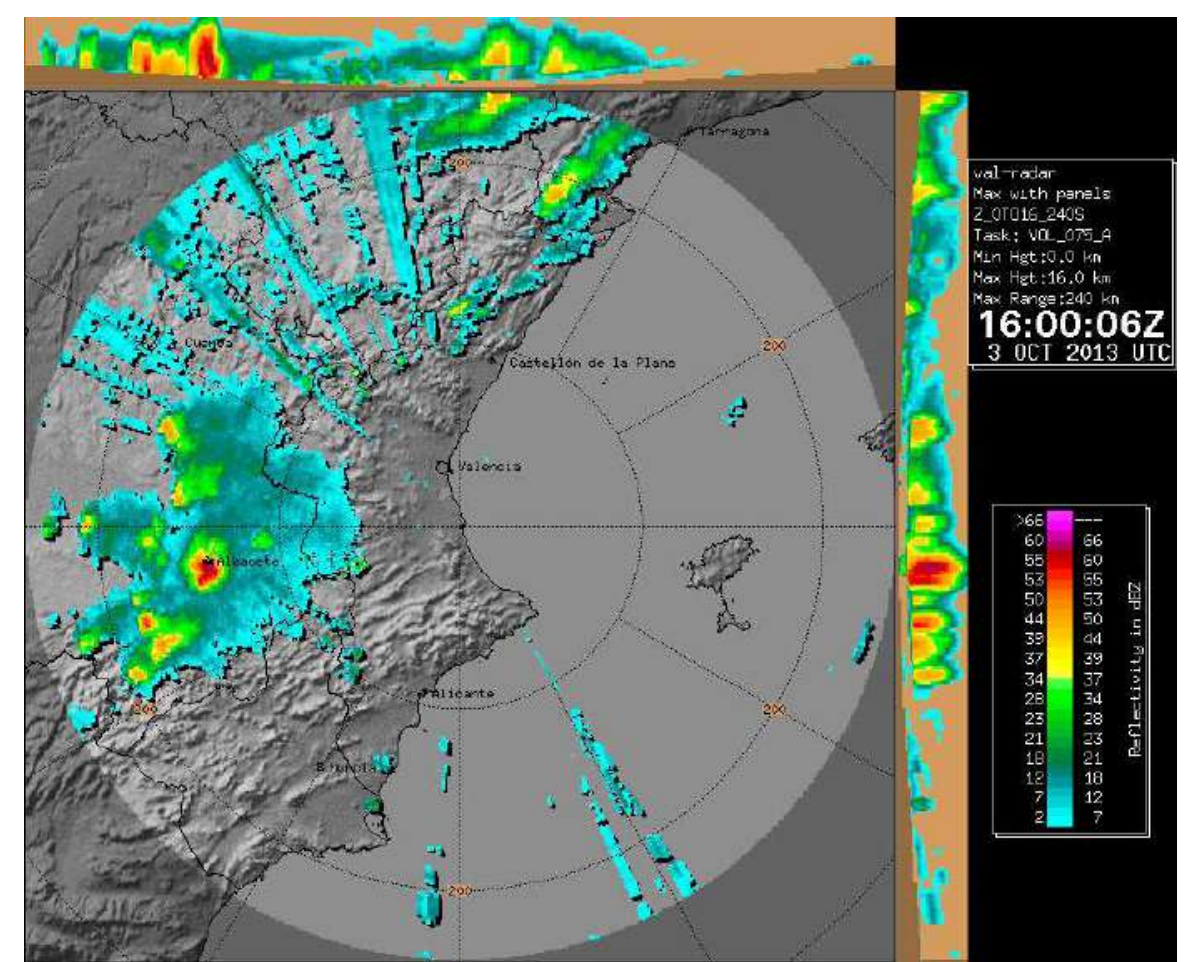

Figura 4.13: Imagen de reflectividad máxima del radar de Valencia de una célula organizada a su paso por la provincia de Albacete, durante la tarde del 3 de octubre de 2013. Imagen de las 16:00 UTC

\section{Fotos:}

La siguiente imagen (figura 4.14) no permite identificar una estructura supercelular, aunque se observa un impresionante arcus o shelf cloud. No se dispone de ninguna otra foto concluyente.

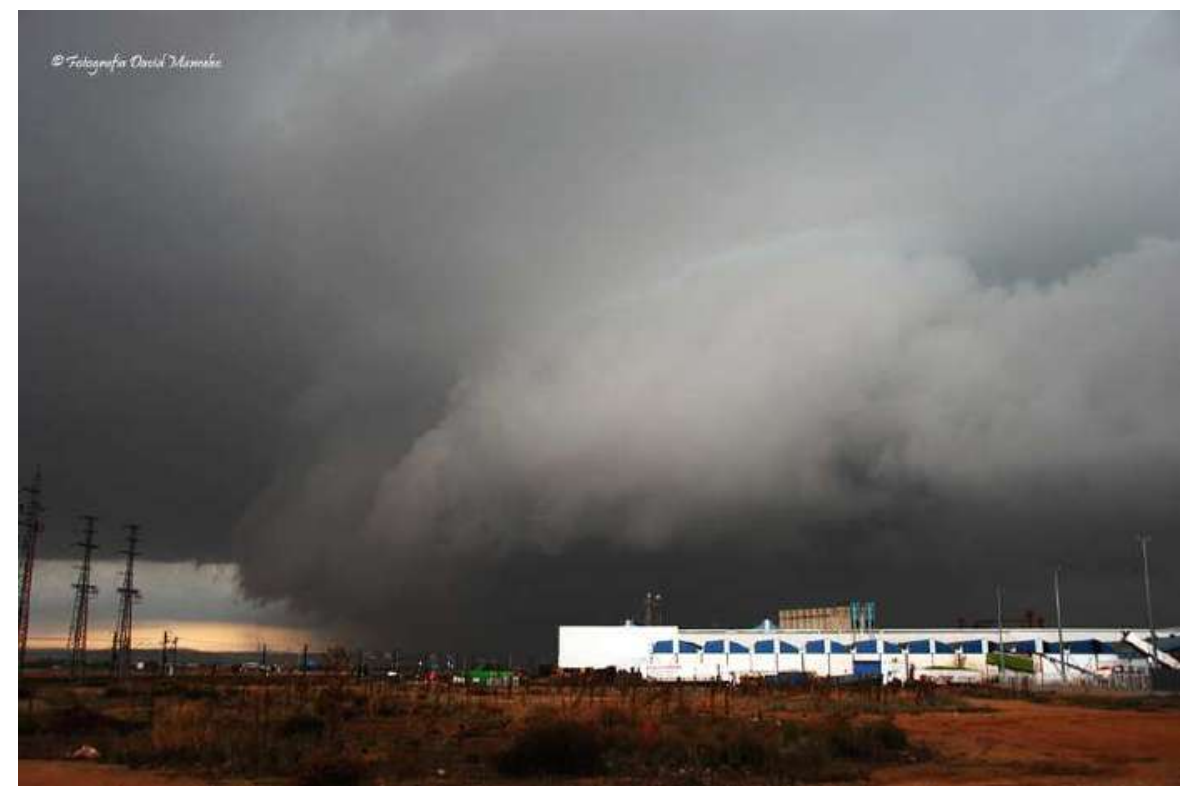

Figura 4.14: Foto de una posible supercélula en Albacete, el 3 de octubre de 2013. Fuente: David Mancebo Atienza. Foro de Meteored.

http://foro.tiempo.com/casos-de-presuntas-supercelulas-en-espana-en-2013-normas-y-listado-pagina-1-t140019.636.html

Por tanto, hay que destacar de este episodio, en primer lugar, que el entorno existente era favorable para el desarrollo supercelular. Resulta también muy llamativa la observación en el radar de una célula de gran extensión, duración, intensidad y velocidad de desplazamiento de suroeste a nordeste, que provocó destacables fenómenos severos a su paso. Estas características se han observado en un tipo de supercélulas en España que presentan gran tamaño y se desplazan muy rápidamente en un entorno de gran cizalladura e inestabilidad.

Por eso, aunque no hay fotos concluyentes de las nubes ni se ha podido detectar el mesociclón por quedar la célula fuera del área de exploración de rango corto del viento radial Doppler, al menos se puede decir que es posible (o incluso probable) que se tratase de una supercélula, aunque este hecho no se puede asegurar completamente en este caso a tenor de la información disponible. 


\section{5.- Conclusiones}

Las supercélulas son tormentas con un alto grado de organización que suelen producir importantes fenómenos severos en superficie. Se trata de tormentas que poseen un profundo y persistente mesociclón. El sentido del giro de la corriente ascendente puede ser ciclónico (mesociclón) o anticiclónico (mesoanticiclón), por lo que existirán supercélulas ciclónicas y supercélulas anticiclónicas. La creación del mesociclón implica la existencia de rotación (vorticidad vertical) en una capa de varios kilómetros de espesor, con un máximo en niveles medios. Dicho máximo situado en el centro de la corriente ascendente está directamente relacionado con el máximo de velocidad ascensional. Otra característica importante es el desvío que sufren en su trayectoria respecto al flujo rector en capas medias o respecto al movimiento observado del resto de las tormentas de su entorno. De hecho, en el hemisferio norte las supercélulas ciclónicas (anticiclónicas) tienden a desviarse hacia la derecha (izquierda) del viento medio, a veces de manera muy significativa.

No es una forma típica de manifestación tormentosa debido al exigente entorno meteorológico que debe estar presente para que puedan generarse, pero tampoco son estructuras raras en España.

En cualquier lugar del mundo las supercélulas presentan una dinámica y unos flujos idénticos, aunque en España la intensidad de las corrientes ascendentes, velocidad de giro, dimensiones horizontal y vertical y duración del mesociclón sean en muchos casos significativamente menores que en las típicas supercélulas de las Ilanuras de los Estados Unidos. En España, un cierto número de supercélulas (10-15\% aprox. según el foro de Meteored) tienen propiedades similares a las minisupercélulas americanas, pues presentan un tamaño reducido en la horizontal y la vertical. Son supercélulas en miniatura ó minisupercélulas, pero en esencia, supercélulas.

Todas las supercélulas contienen rotación a escala de la tormenta, detectable mediante la visualización de estrías en forma de sacacorchos en la corriente ascendente. Dentro de las categorías de supercélulas hay diferencias en función de su aspecto, especialmente a partir de la cantidad y distribución espacial de la precipitación (si cae cerca o lejos de la corriente ascendente), lo cual permite distinguir unas supercélulas de otras, distinguiéndose las clásicas, las de elevada cantidad de precipitación y las de baja tasa de precipitación.

Las supercélulas se forman en entornos con destacables valores de cizalladura vertical de viento, o sea en entornos con hodógrafas largas. Una hodógrafa larga y recta suele llevar a la generación de un storm splitting (división tormentosa), con una célula ciclónica (derecha), y otra anticiclónica (izquierda). Climatológicamente, aunque ambas células (o ninguna) pueden progresar a supercélula, es más probable que lo haga la célula ciclónica. En cambio, una hodógrafa larga y curva puede conducir a la generación de una supercélula con giro ciclónico (en casos de cizalladura clockwise: variación del viento con la altura en el mismo sentido de las agujas del reloj) o de una supercélula con giro anticiclónico (en casos de cizalladura counterclockwise). La existencia de una gran cizalladura vertical en los primeros kilómetros genera vorticidad horizontal. A la vorticidad la podemos descomponer en dos componentes: vorticidad streamwise (paralela al flujo relativo que alimenta la tormenta en capas bajas), y vorticidad crosswise (perpendicular al flujo relativo que alimenta la tomenta). La magnitud que cuantifica esta disponibilidad del entorno para que se genere una supercélula es la helicidad relativa a la tormenta, y da una idea del valor de la componente streamwise de la vorticidad. En el caso de que predomine la vorticidad streamwise (paralela al flujo alimentador), se generará una supercélula con un updraft (corriente ascendente) con rotación neta. $\mathrm{Y}$ en el caso de que predomine la vorticidad crosswise (perpendicular al flujo alimentador), se formará un storm-splitting, o sea una división de la tormenta en dos células simétricas pero ninguna con rotación neta en su corriente ascendente (updraft). Ambas se moverían separándose paulatinamente, y debido a ese desvío alguna de las dos podrá adquirir posteriormente vorticidad streamwise y por tanto evolucionar a supercélula.

Empíricamente, a partir de estimaciones de modelos numéricos, se ha constatado que en España los entornos favorables a supercélulas superan en bastantes casos ciertos valores umbrales que se encuentran realmente alejados de los de referencia de las típicas supercélulas de las llanuras de Estados Unidos. Así para las supercélulas en España, en un número significativo de los casos se superan simultáneamente los tres valores de variables consideradas clave al respecto (SBCAPE $>200 \mathrm{~J} / \mathrm{Kg}, \mathrm{ClZ} 6>9 \mathrm{~m} / \mathrm{s}$ y SRH3 $>100 \mathrm{~m}^{2} / \mathrm{s}^{2}$ ). En ocasiones, los modelos no son capaces de simular adecuadamente el valor local de la helicidad relativa a la tormenta (dependiente en gran medida del tipo del método usado para calcularla), parámetro decisivo en la génesis supercelular, que puede variar mucho respecto al del entorno debido a diversas causas. Por ello nos encontramos casos en los que la SRH3 prevista por los modelos es muy inferior a ese valor umbral.

Para poder asegurar que se ha identificado visualmente una supercélula, hay que apreciar claramente un giro mesoscalar a escala tormentosa, de cierta profundidad, y con una duración mínima de unos 10 ó 20 minutos, aproximadamente. 
En bastantes ocasiones resulta de gran ayuda la visualización posterior de una animación filmada mediante la técnica time lapse, que permite imprimirle más velocidad a la película grabada y así poder observar con nitidez el giro solidario, extenso y persistente del mesociclón. Por tanto, a la hora de identificar visualmente una supercélula, hay tres características fundamentales que debemos poder distinguir:

- Una rotación persistente en la corriente ascendente, zona situada por encima de la base circular libre de lluvia,

- Una corriente descendente principal de precipitación (FFD) desacoplada de la anterior, y

- Una zona trasera de descenso $(R F D)$, que es una región de aire seco situada en la parte de atrás de la circulación de la tormenta, acompañada de un área reducida y concentrada de precipitación.

Pero también hay algunas estructuras típicas que debemos saber distinguir: la zona de alimentación en niveles bajos. El yunque masivo, con la cizalladura hacia atrás en su parte trasera, en oposición al flujo en niveles altos. La torre tormentosa principal, que es en realidad la representación de la corriente ascendente desde su base próxima al suelo hasta el tope nuboso. Los numerosos mammatus. Un overshooting o torreón que se puede identificar si nos encontramos suficientemente lejos de la tormenta. Bandas en los bordes de la nube confiriendo un aspecto de sacacorchos (corkscrew) indicativo del giro mesoescalar, o en forma de estriaciones curvadas de manera similar a las rayas de los postes de los antiguos barberos (barber pole), que son la manifestación del giro de la corriente ascendente. Otro elemento destacable es la presencia de una base circular libre de precipitación que es precisamente la base de la corriente ascendente en rotación (mesociclón) que sostiene precipitación y granizo sin que caigan al suelo en esta zona. De esta base libre de precipitación suele colgar hacia abajo una nube pared (wall cloud) en forma de pezuña de caballo, a veces en rotación. No obstante hay que tener en cuenta que podemos ver wall clouds incluso en estructuras no severas, por lo que el hecho de ver un wall cloud no significa estar ante una supercélula. $Y$ también son frecuentes las identificaciones de la alimentación del flujo en niveles bajos, con nubes tipo inflow cloud, beaver tail y tail cloud. La tail cloud es una de las características visuales más exclusivas de las supercélulas. También hay nubosidad periférica espectacular ligada a la zona de salida del aire, tales como el frente de racha (flanking line) o las nubes estante 0 cinturón (shelf clouds). En la fase de colapso de la corriente ascendente supercelular (etapa de decaimiento), la base circular libre de precipitación suele ser ocluida de arriba hacia abajo por la corriente descendente del flanco trasero surgiendo lo que se conoce como clear slot, que es precisamente la zona de nube más clara, de tono verdoso o incluso cielo despejado fruto de la evaporación y disipación de la corriente ascendente debido al aire seco que desciende desde arriba. No obstante, sólo en algunas condiciones es posible una identificación visual de una supercélula, aparte de la necesidad de una experiencia previa en el avistamiento de este tipo de estructuras.

Una identificación categórica de una supercélula se puede realizar a partir de la observación radar, cuando se localiza la rotación del mesociclón (o mesoanticiclón) a partir del producto viento radial Doppler, en el que se debe comprobar la existencia de dos máximos relativos de viento opuestos, muy cercanos y que cumplan la propiedad de que el segmento que los une sea más o menos perpendicular a la radial al punto donde está localizado el radar. Esta característica es la prueba inequívoca de que la tormenta es supercelular. Sin embargo, a veces es difícil detectar el mesociclón, sobre todo durante varias imágenes consecutivas, debido a la estrategia actual de exploración del sistema de radares de AEMET, a la compleja orografía y a las características de algunas supercélulas en España, con corta duración y extensión del mesociclón. Parece claro que la estrategia de exploración actual de los radares de AEMET no es la más apropiada para detectar con claridad los patrones de viento radial típicos del mesociclón, especialmente los de niveles medios. Ello es debido, principalmente, a que sólo se realizan dos barridos bajos de viento radial $\left(0.5^{\circ}\right.$ y $\left.1.4^{\circ}\right)$, no realizándose más barridos de este tipo hasta la elevación de $7.7^{\circ}$. Por tanto, carecemos de datos de viento radial en una porción importante del volumen explorado por el radar, la comprendida entre $1.4^{\circ}$ y $7.7^{\circ}$.

Así pues si sólo tuviéramos en cuenta la identificación radar del mesociclón, como prueba irrefutable y única de la existencia de una supercélula, pocas veces en España podríamos hablar de supercélulas según la estrategia actual de exploración radar. Por tanto, habrá que recurrir a la identificación de diversos patrones radar cuya coexistencia conjunta nos daría una confianza media-alta de que estamos ante una supercélula (por ejemplo la observación de ecos elevados e intensos, la zona de eco débil acotada, el gancho, un fuerte gradiente de reflectividad, el desvío respecto al viento medio rector, estructura V-notch, etc.). En consecuencia, si no observamos el mesociclón persistente en radar (al menos durante $\mathbf{2 0}$ minutos: $\mathbf{2}$ imágenes consecutivas, algo en general difícil de observar por diferentes condicionantes), será la mayor o menor concurrencia de otros patrones típicos de supercélulas la que nos proporcionará una mayor o menor confianza sobre el carácter supercelular de la tormenta. 
Estos patrones serán de varios tipos dependiendo del método de observación o diagnóstico. Entre estos están los siguientes:

- Identificación visual (fotografías/videos) de las estructuras nubosas típicamente asociadas a supercélulas (sacacorchos, cola de castor, nube pared, tail-cloud, clear slot, etc.). No obstante la observación visual puede ser categórica en el caso de que sea realizada por personal experto en la identificación de supercélulas.

- Entornos meteorológicos de mesoescala propicios para la formación de supercélulas (convección muy activa y valores elevados de cizalladura y helicidad relativa a la tormenta)

- Identificación de elementos típicos en radar: extensión e intensidad de ecos, alto gradiente de reflectividad, gancho en la horizontal del campo de reflectividad, BWER o gancho en la vertical, desvío respecto a viento medio en capas medias, storm-splitting (aunque no todos los storm-splitting producen supercélulas ni mucho menos todas las supercélulas proceden de un storm-splitting).

- Efectos severos en superficie. Aunque hay otras estructuras no supercelulares que pueden generar efectos severos similares a las supercélulas, la mayor parte de casos de granizo de diámetro superior a $5 \mathrm{~cm}$, son de procedencia supercelular. También, los tornados iguales o superiores en intensidad a un EF-3 son casi siempre procedentes de una supercélula.

Por último, cabe citar que diversos meteorólogos expertos americanos consultados, coinciden en señalar que las supercélulas en España no son fenómenos raros y que presentan la misma física que las de los Estados Unidos, aunque en general con menor capacidad destructiva que las típicas de las Grandes Llanuras (Great Plains) americanas.

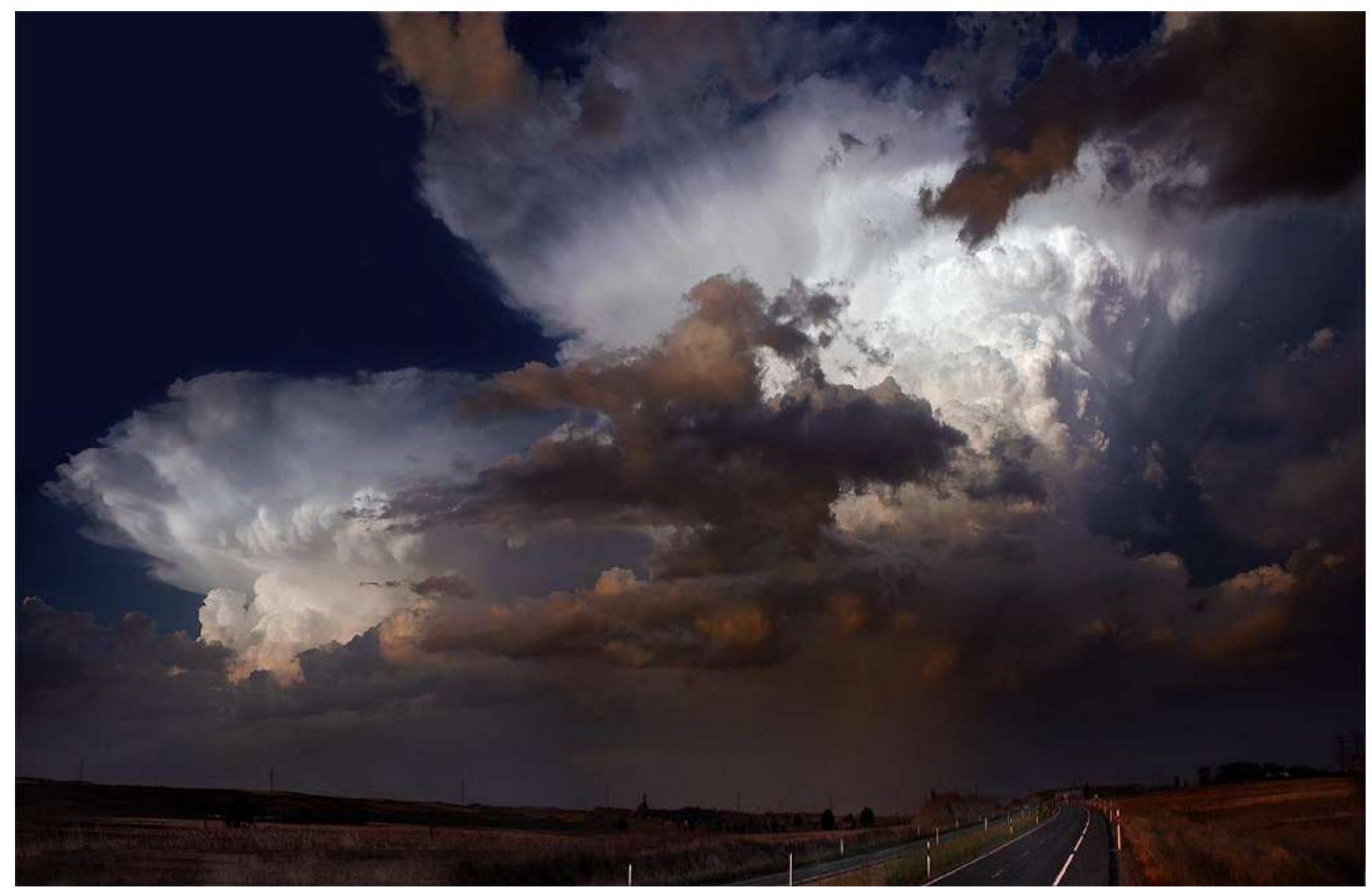

Figura 5.1. "Storm-splitting" desarrollado sobre Madrid-Guadalajara, 7 de Septiembre de 2004. Foto J.A.Quirantes 


\section{6.- Referencias}

- Bluestein H.B., and C. R. Parks, 1983: A synoptic and photographic climatology of low-precipitation severe thunderstorms in the southern plains. Mon. Wea. Rev., 111, 2034-2046.

- Browning, K. A., 1962: Cellular structure of convective storms. Meteor. Mag., 91, 341-350.

- Browning, K. A., 1964: Airflow and precipitation trajectories within severe local storms which travel to the right of the winds. J. Atmos. Sci., 21, 634-639.

- Burgess, D.W., R.R. Lee, S.S. Parker, and D.L. Floyd, 1995: A Study of Mini Supercell Thunderstorms. Preprints, 27th Conf. On Radar Meteor., Vail, CO., Amer. Meteor. Soc., 4-6.

- COMET. "Weather radar Fundamentals" https://www.meted.ucar.edu/radar/basic wxradar/print.htm

- COMET. "Principios de conveccion I. Empuje Hidrostático y CAPE". https://www.meted.ucar.edu/mesoprim/cape es/

- COMET. "Principios de conveccion II. Uso de la hodógrafa". http://www.meted.ucar.edu/mesoprim/hodograf es/index.htm

- COMET (UCAR, http://www.comet.ucar.edu/): Principios de Convección III: cizalladura y tormentas convectivas.

- COMET (UCAR, http://www.comet.ucar.edu/): Señales de Radar Características de tiempo convectivo severo.

- Doswell C.A. III and Burgess D.W., 1993: Tornadoes and tornadic storms: A review of conceptual models. The Tornado: Its Structure, Dynamics, Prediction and Hazards, Geophys. Monogr., No. 79, Amer. Geophys Union, 161-172.

- Doswell C.A. III, 1996: What is a supercell? http://www.cimms.ou.edu/ doswell/Conference papers/SELS96/Supercell.html

- Lemon, L.R., Doswell, C.A. III, 1979: Severe Thunderstorm evolution and mesocyclone structure relates as to tornadogenesis. Mon. Wea. Rev., 07, 1184-1197.

- Lemon, L.R., 1980: Severe Thunderstorm Radar Identification Techniques and Warning Criteria. NOAA Tec. Memo. NWS NSSFC-2, Kansas City, 67 pp. and mesocyclone structure relates as to tornadogenesis. Mon. Wea. Rev., 07, 1184-1197.

- Markowski, P. M., J. M. Straka, E. N. Rasmussen, and D. O. Blanchard, 1998b: Variability of storm-relative helicity during VORTEX. Mon. Wea. Rev, 126, 2959-2971.

- Markowski P. and Richardson Y., 2010: Mesoscale Meteorology in Midlatitudes. Wiley-Blackwell. ISBN: 9780470742136. $430 \mathrm{pp}$.

- Martín León, F. y Riosalido Alonso,R. Modelos Conceptuales de Tormentas: Radar y Rayos. Módulos TempoWeb del ATAP. 1999. AEMET.

- National Weather Service (NOAA), 2011: Weather Spotter's Field Guide. http://www.nws.noaa.gov/os/brochures/SGJune6-11.pdf

- Quirantes, J. A., 2008: Nociones básicas sobre supercélulas. http://www.divulgameteo.es/uploads/Supercélulas.pdf

- Quirantes, J.A., 2012: Introducción a las supercélulas. Taller de convección para predictores del Centro Nacional de Predicción. Presentación interna. AEMET.

- Weisman, M. L., and J. B. Klemp, 1982: The dependence of numerically simulated convective storms on wind shear and buoyancy. Mon. Wea. Rev., 110: 504-520.

- Weisman M.L. and J.B. Klemp, 1986: Characteristics of isolated convective storms. Mesoscale Meteorology and Forecasting (P.S. Ray, Ed.), Amer. Meteor. Soc., 331-358.

- Wicker, L. J., and L. Cantrell, 1996: The Role of Vertical Buoyancy Distributions in Miniature Supercells. Preprints, 18th Conference on Severe Local Storms, San Francisco, CA, American Meteorological Society, 225-229.

- Wikipedia. "Escala Fujita Mejorada" http://es.wikipedia.org/wiki/Escala Fujita mejorada 